UNIVERSIDADE ESTADUAL PAULISTA "JULIO DE MESQUITA FILHO" FACULDADE DE CIÊNCIAS AGRÁRIAS E VETERINÁRIAS CÂMPUS DE JABOTICABAL

\title{
PERÍODO ANTERIOR DA INTERFERÊNCIA DAS PLANTAS DANINHAS NO AMENDOIM EM RESPOSTA A DENSIDADE DE PLANTAS E ESPAÇAMENTOS
}

Nilton Luiz de Souza J unior Biólogo

\footnotetext{
JABOTICABAL - SÃO PAULO - BRASIL

Fevereiro de 2010
} 
UNIVERSIDADE ESTADUAL PAULISTA "JULIO DE MESQUITA FILHO" FACULDADE DE CIÊNCIAS AGRÁRIAS E VETERINÁRIAS CÂMPUS DE JABOTICABAL

\section{PERÍODO ANTERIOR DA INTERFERÊNCIA DAS PLANTAS DANINHAS NO AMENDOIM EM RESPOSTA A DENSIDADE DE PLANTAS E ESPAÇAMENTOS}

Nilton Luiz de Souza Junior

Orientador: Prof. Dr. Pedro Luis da Costa Aguiar Alves

Dissertação apresentada à Faculdade de Ciências Agrárias e Veterinárias - Unesp, Câmpus de Jaboticabal, como parte das exigências para a obtenção do título de Mestre em Agronomia (Produção Vegetal).

JABOTICABAL - SÃO PAULO - BRASIL

Fevereiro de 2010 


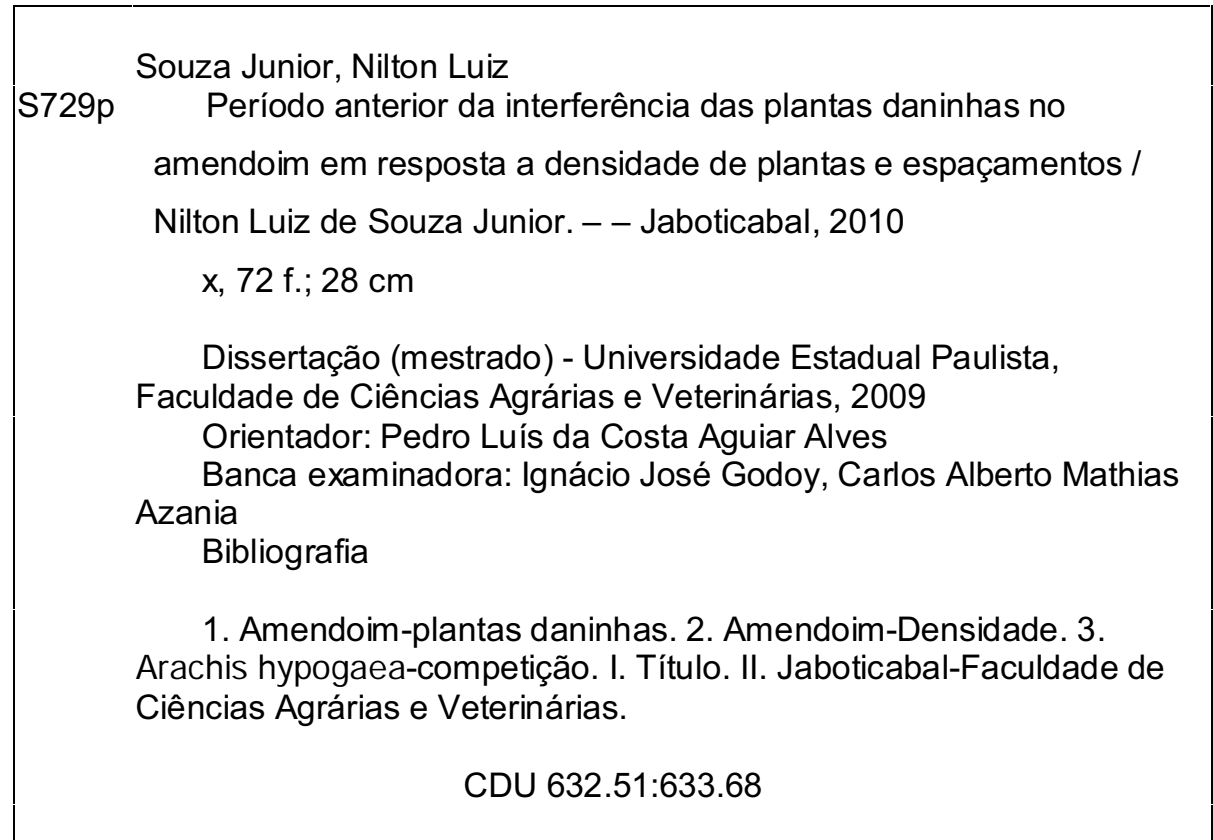

Ficha catalográfica elaborada pela Seção Técnica de Aquisição e Tratamento da Informação - Serviço Técnico de Biblioteca e Documentação - UNESP, Câmpus de Jaboticabal. 


\section{DADOS CURRICULARES DO AUTOR}

NILTON LUIZ DE SOUZA J UNIOR - nascido na cidade de Jaboticabal, Estado de São Paulo, no dia 25 de julho de 1983, é Biólogo graduado pela Universidade Estadual Paulista "Júlio de Mesquita Filho", na Faculdade de Ciências Agrárias e Veterinárias Campus Jaboticabal - junto à I turma do curso de Biologia (2007). Durante a graduação, estagiou no Laboratório de Biologia e Manejo de Plantas Daninhas e desenvolveu projetos científicos na área de Biologia e Manejo de Plantas Daninhas. Em 2008 ingressou no curso de Mestrado em Produção Vegetal, na mesma instituição, atuando nas mesmas áreas de pesquisa iniciada durante a graduação. 
Aos meus pais, Nilton e Neuci,

por tanto carinho, amor, dedicação e incentivo.

Obrigado por fazerem parte da minha vida.

DEDICO.

A minha irmã Nidiane, pelos anos

De convívio e por tudo que

Aprendemos juntos.

OFEREÇO.

AcroPDF - A Quality PDF Writer and PDF Converter to create PDF files. To remove the line, buy a license. 


\section{AGRADECIMENTOS}

Agradeço a Deus pela dádiva da vida e por ter me dado força durante toda a minha vida.

Ao professor Dr. Pedro Luís da Costa Aguiar Alves pelos ensinamentos, paciência e pela oportunidade da realização do curso de mestrado.

À Universidade Estadual Paulista - Faculdade de Ciências Agrárias e Veterinárias (FCAV/UNESP), Jaboticabal - SP e ao Departamento de Biologia Aplicada a Agropecuária por toda a infra-estrutura durante a realização do experimento.

Aos funcionários da Fazenda de Pesquisa, Ensino e Produção por todo auxílio durante a execução e manutenção do experimento.

Ao senhor Nilton Luiz de Souza pelo amparo durante a execução do ensaio.

Aos amigos de funcionários do Laboratório de Biologia de Manejo de Plantas Daninhas que muito me ajudaram durante todos os anos que ai estive.

Aos professores Silvano Bianco, Maria Aparecida Pessoa da Cruz Centurion, Ignácio José Godoy, Carlos Alberto Mathias Azânia, Maria do Carmo Morelo Damasceno Pavani, pelas sugestões, atenção e esclarecimentos de dúvidas.

Aos companheiros e amigos na qual tive o prazer de conviver durante o curso de mestrado, pelo companheirismo e amizade nos momentos bons e difíceis.

Agradeço a Cooperativa de Plantadores de Cana da Zona de Guariba (COPLANA) pela semente utilizada no experimento e pelas recomendações agronômicas.

Fernanda obrigado por todo carinho, atenção e paciência.

A todos aqueles que de alguma forma contribuíram e consideram-se responsáveis pela realização deste trabalho, meus sinceros agradecimentos.

\section{MUITO OBRIGADO}




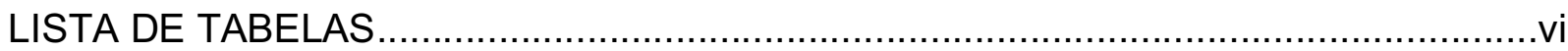

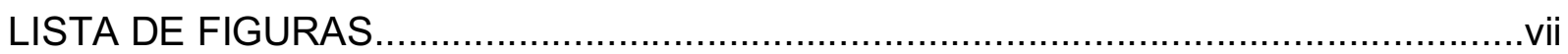

RESUMO

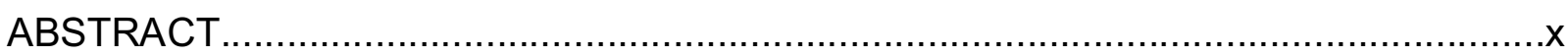

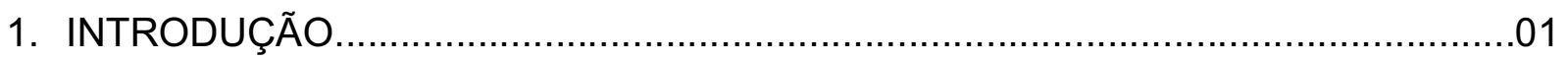

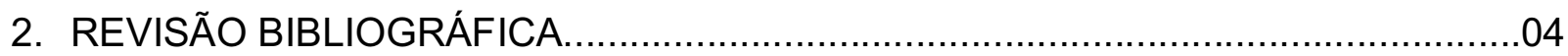

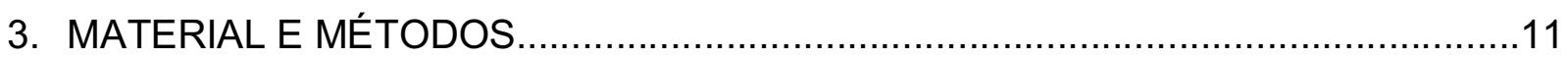

3.1. Descrição e preparo do solo..............................................................11

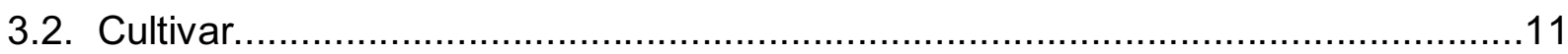

3.3. Delineamento e Tratamentos experimentais...............................................12

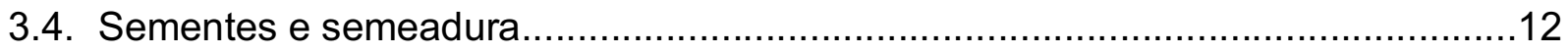

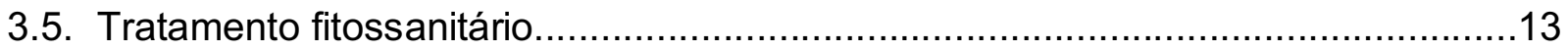

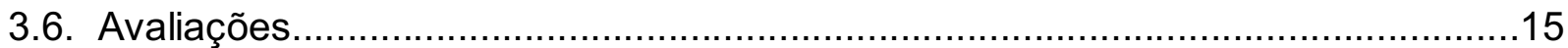

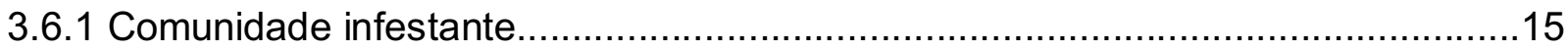

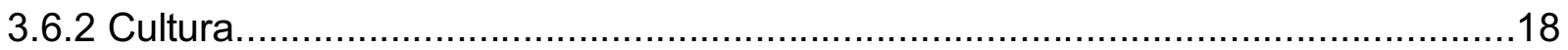

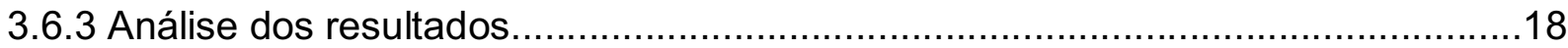

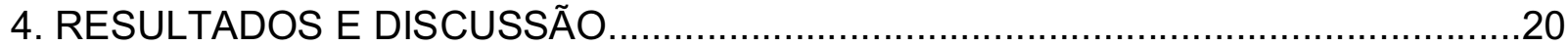

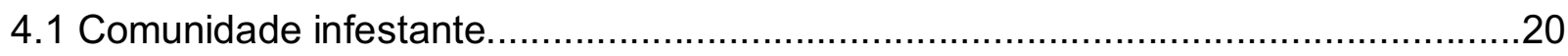

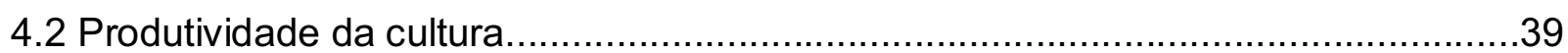

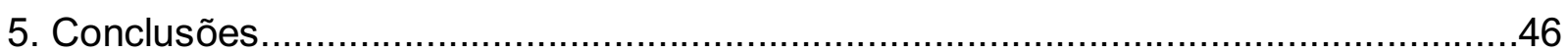

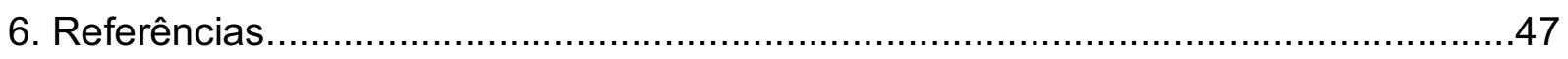

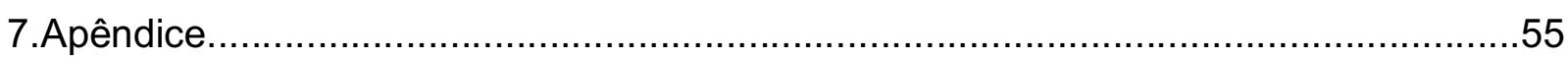




\section{LISTA DE TABELAS}

Página

Tabela 1. Principais características da cultivar IAC Runner 886 (Godoy, 2002).

Tabela 2. População da cultura do amendoim em função do espaçamento e da densidade de plantas. $\mathrm{m}^{-1}$. Jaboticabal, SP, 2007/2008

Tabela 3. Nome comercial, nome químico, dose e data de aplicação dos produtos fitossanitários empregados no decorrer do período experimental. Jaboticabal, SP, 2007/2008

Tabela 4. Produção final de amendoim em vagens ( $\left.\mathrm{kg} \mathrm{ha}^{-1}\right)$, em função da densidade de plantas e períodos de convivência. Jaboticabal, SP, 2007/2008. 39

Tabela 5. Parâmetros da equação sigmoidal de Boltzman obtidos com a análise dos dados de produção do amendoim com casca para o espaçamento de 0,60 m e densidade de semeadura de 5,10 e 15 plantas. $\mathrm{m}^{-1}$. Jaboticabal, SP, $2007 / 208$ 44

Tabela 6. Parâmetros da equação sigmoidal de Boltzman obtidos com a análise dos dados de produção do amendoim com casca para o espaçamento de 0,90 m e densidade de semeadura de 5,10 e 15 plantas. $\mathrm{m}^{-1}$. Jaboticabal, SP, $2007 / 208$ 


\section{LISTA DE FIGURAS}

Figura 1. Densidade da comunidade infestante no espaçamento entrelinhas de $0,60 \mathrm{~m}$ nas densidades de semeadura de 5 (A), 10 (B) e 15 (C) plantas. $\mathrm{m}^{-1}$, em função dos períodos de convivência com a cultura do amendoim. Jaboticabal, SP, 2007/2008.

Figura 2. Densidade da comunidade das plantas daninhas no espaçamento de $0,90 \mathrm{~m}$ nas densidades de 5 plantas. $\mathrm{m}^{-1}(\mathrm{~A}), 10$ plantas. $\mathrm{m}^{-1}(\mathrm{~B})$ e 15 plantas. $\mathrm{m}^{-1}(\mathrm{C})$, em função dos períodos de convivência com a cultura do amendoim. Jaboticabal, SP, 2007/2008.

Figura 3. Massa seca total das plantas daninhas no espaçamento de $0,60 \mathrm{~m}$ nas densidades de 15 plantas. $\mathrm{m}^{-1}(\mathrm{~A}), 10$ plantas. $\mathrm{m}^{-1}(\mathrm{~B})$ e 15 plantas. $\mathrm{m}^{-1}(\mathrm{C})$, em função dos períodos de convivência com a cultura do amendoim. Jaboticabal, SP, 2007/2008.

Figura 4. Massa seca total das plantas daninhas no espaçamento de $0,90 \mathrm{~m}$ nas densidades de 5 plantas. $\mathrm{m}^{-1}(\mathrm{~A}), 10$ plantas. $\mathrm{m}^{-1}(\mathrm{~B})$ e 15 plantas. $\mathrm{m}^{-1}(\mathrm{C})$, em função dos períodos de convivência com a cultura do amendoim. Jaboticabal, SP, 2007/2008.

Figura 5. Importância relativa do capim-colchão (DIGSP), capim-colonião (PANMA), carrapicho-de-carneiro (ACNHI), tiririca (CYPRO) e demais plantas daninhas infestando a cultura do amendoim no espaçamento de 0,60 m entrelinhas e densidade de semeadura de 5 plantas. $\mathrm{m}^{-1}$.

Figura 6. Importância relativa do capim-colchão (DIGSP), capim-colonião (PANMA), carrapicho-de-carneiro (ACNHI), tiririca (CYPRO) e demais plantas daninhas infestando a cultura do amendoim no espaçamento de 0,60 m entrelinhas e densidade de semeadura de 10 plantas. $\mathrm{m}^{-1}$.

Figura 7. Importância relativa do capim-colchão (DIGSP), capim-colonião (PANMA), carrapicho-de-carneiro (ACNHI), tiririca (CYPRO) e demais plantas daninhas infestando a cultura do amendoim no espaçamento de 0,60 m entrelinhas e densidade de semeadura de 15 plantas. $\mathrm{m}^{-1}$ 
Figura 8. Importância relativa do capim-colchão (DIGSP), capim-colonião (PANMA), carrapicho-de-carneiro (ACNHI), tiririca (CYPRO) e demais plantas daninhas infestando a cultura do amendoim no espaçamento de $0,90 \mathrm{~m}$ entrelinhas e densidade de semeadura de 5 plantas. $\mathrm{m}^{-1}$ 35

Figura 9. Importância relativa do capim-colchão (DIGSP), capim-colonião (PANMA), carrapicho-de-carneiro (ACNHI), tiririca (CYPRO) e demais plantas daninhas infestando a cultura do amendoim no espaçamento de $0,90 \mathrm{~m}$ entrelinhas $\mathrm{e}$ densidade de semeadura de 10 plantas. $\mathrm{m}^{-1}$

Figura 10. Importância relativa do capim-colchão (DIGSP), capim-colonião (PANMA), carrapicho-de-carneiro (ACNHI), tiririca (CYPRO) e demais plantas daninhas infestando a cultura do amendoim no espaçamento de 0,90 m entrelinhas e densidade de semeadura de 15 plantas. $\mathrm{m}^{-1}$

Figura 11. Produção de amendoim em casca, no espaçamento de 0,60 m e densidade de semeadura de 5,10 e 15 plantas. ${ }^{-1}$, em função dos períodos de convivência. Jaboticabal, SP, 2007/2008. 40

Figura 12. Produção de amendoim em casca, no espaçamento de 0,90 m e densidade de semeadura de 5,10 e 15 plantas. $m^{-1}$, em função dos períodos de convivência. Jaboticabal, SP, 2007/2008 


\section{PERÍODO ANTERIOR DA INTERFERÊNCIA DAS PLANTAS DANINHAS NO AMENDOIM EM REPOSTA A DENSIDADE DE PLANTAS E ESPAÇAMENTOS}

Resumo - O objetivo do trabalho foi avaliar os efeitos da diminuição do espaçamento entrelinhas e da densidade populacional do amendoim rasteiro, cultivar Runner IAC 886 sobre o período anterior de interferência (PAI) das plantas daninhas e produtividade da cultura. Foram estudados dois espaçamentos entrelinhas (60 e $90 \mathrm{~cm}$ ) e, em cada qual, os tratamentos constaram de três densidades $\left(5,10\right.$ e 15 plantas. $\left.\mathrm{m}^{-1}\right)$ combinadas com nove períodos de convivência com as plantas daninhas $(0,15,30,45,60,75,90,105$ e 120 dias após a emergência - DAE). Para cada espaçamento o delineamento experimental foi o de blocos casualizados com parcelas subdivididas, com três repetições. Na análise da importância relativa (IR), que é um índice complexo que envolve os três fatores anteriores, sendo calculado pelo somatório da constância, densidade e dominância relativas. Das espécies de plantas daninhas presentes durante todo o período experimental, quatro espécies se destacaram: Digitaria spp. (capimcolchão), Panicum maximum (capim-colonião), Acanthospermum hispidum (carrapichode-carneiro) e Cyperus rotundus (tiririca). Verificou-se que independente do espaçamento e da densidade a tiririca foi à espécie com maior IR durante o período inicial de desenvolvimento da cultura. O capim-colonião apresentou elevada IR aos 30 DAE devido a brotação de touceiras. O carrapicho-de-carneiro se destacava, na maioria das vezes, depois das outras espécies de plantas daninhas. No espaçamento de 0,90 $\mathrm{m}$ o capim-colchão foi a espécie de maior IR. No espaçamento de 0,60 $\mathrm{m}$ e densidade de semeadura de 5, 10 e 15 plantas. $\mathrm{m}^{-1}$, o PAI foide 87, 39 e 11 DAE, respectivamente, enquanto para o espaçamento de 0,90 m estes foram de 4,41 e 11 DAE.

Palavras-chave: Arachis hypogaea, competição, fitossociologia 


\title{
PERIOD BEFORE WEED INTERFERENCE IN PEANUT IN RESPONSE OF PLANT DENSITY AND SPACINGS
}

\begin{abstract}
The objective of this study was to evaluate the effects of the decrease in row spacing and density of creeping peanut cultivar IAC Runner 886 on the previous period of interference (PAI) weed and crop productivity. We studied two row spacings (60 and $90 \mathrm{~cm})$, and each, treatments consisted of three densities $(5,10$ and 15 plants.m-1) combined with nine periods of coexistence with the weeds $(0,15,30,45,60,75,90,105$ and 120 days after emergence - DAE). For each row the experimental design was a randomized split-plot design with three replications. In the analysis of the relative importance (IR), is a complex index that involves the three factors above, is calculated by the sum of constant, relatives density and dominance. The weed species present throughout the experimental period, four species are highlighted: Digitaria spp., Panicum maximum, Acanthospermum hispidum and Cyperus rotundus. It was found that $C$. rotundus of the spacing and density of the weed was the species with the highest IR during the initial period of development of culture. P. maximum IR 30 DAE because sprout clumps. The A. hispidum out, in most cases, after the other weed species. The spacing of 0.90 mo Digitaria spp. was the kind of higher IR. Spaced $0.60 \mathrm{~m}$ seeding rate of 5, 10 and 15 plants.m-1, PAI felled was 87, 39 and 11 DAE, respectively, while for the spacing of $0.90 \mathrm{~m}$ they were 4,41 and $11 \mathrm{DAE}$
\end{abstract}

Key Words: Arachis hypogaea, competition, phytosociology 


\section{INTRODUÇÃO}

O amendoim ganhou importância econômica tanto no cenário nacional quanto internacional, como alimento, devido aos seus grãos possuírem sabor agradável e inigualável, sendo consumidos "in natura", torrados, ou empregados na culinária ou na produção de doces (SANTOS et al., 1997). Seu óleo pode ser utilizado diretamente na alimentação humana e na indústria de tintas, de conserva, de produtos farmacêuticos e tem potencial na produção de biodiesel (GODOY et al., 2005). A torta, subproduto da extração do óleo, é rica em proteínas (aproximadamente 45\%), sendo destinada à alimentação animal (CARNEIRO, 2006).

O consumo nacional e mundial entre os anos de 2000 a 2005 cresceu em torno de $23 \%$ e $5 \%$, respectivamente (LOURENZANI \& LOURENZANI, 2009). Para atender essa demanda, novas cultivares, técnicas de cultivo e novas máquinas foram introduzidas no Brasil, o que possibilitou aos produtores aumentar a área de plantio de 95.000 ha em 2002 para mais de 116.900 ha na última safra, o que representou um aumento de $23 \%$ (IEA, 2009). Concomitante, ocorreu também um aumento de $40 \%$ na produtividade da cultura, passando de $2.700 \mathrm{~kg} \cdot \mathrm{ha}^{-1}$ para $3.800 \mathrm{~kg} \cdot \mathrm{ha}^{-1}$ (IEA, 2009). Este aumento da produção e da produtividade deve-se ao aumento da área semeada e a utilização de novas cultivares que apresentam maior produtividade. Por essas características, o Brasil destaca-se como sendo um grande produtor de amendoim e grande possibilidade de expansão.

Esse aumento da área plantada de amendoim está associada à cultura cananieria uma vez que o amendoim é uma ótima opção para as áreas de reforma de canaviais, particularmente no Estado de São Paulo, maior produtor, com cerca de $78 \%$ do total nacional (AGRIANUAL, 2009).

A introdução de cultivares rasteiras e a mecanização de todo o processo produtivo do amendoim trouxeram benefícios para os agricultores, como uma maior capacidade produtiva com menor utilização de mão-de-obra. Entretanto, as novas máquinas impuseram um espaçamento diferente do até então utilizado pelos agricultores, passando dos 45 centímetros para os 90 centímetros. Esse novo 
espaçamento é utilizado devido as características dessas novas cultivares, que por serem de hábito de crescimento prostado, requerem espaçamentos mais largos, para uma maior produtividade. Porém, isso propiciou uma nova dinâmica da população de plantas daninhas, uma vez que o controle exercido pela cultura passou a ser mais tardio, permitindo que a comunidade infestante se estabeleça mais cedo e assim manifeste sua interferência sobre a cultura.

Nos últimos anos, o custo de produção da cultura teve um aumento de, aproximadamente, $12 \%$, situando em torno de $\mathrm{R} \$ 31,50$ saca $^{-1}$ (IEA, 2009). Dentre os gastos previstos na produção, a semente representa um custo elevado, obrigando a que cada vez mais, se racionalize e se otimize o uso dessas. Por isso, novas densidades vêm sendo testadas e, com a diminuição da densidade de plantas da cultura, a comunidade infestante não terá tanta competição interespecífica por espaço, nutrientes e água.

Em contrapartida, essas novas cultivares apresentam hábito de crescimento rasteiro, o que faz com que ocorra o completo fechamento nas entrelinhas com o desenvolvimento das plantas, gerando assim uma pressão negativa sobre as plantas daninhas, principalmente pelo sombreamento.

Os fatores que afetam o grau de interferência entre as culturas agrícolas e a comunidade infestante podem ser ligados à cultura (espécie, espaçamento e densidade de plantio), à comunidade infestante (composição específica, densidade e distribuição) e ao ambiente (BLEASDALE, 1960). Depende, também, da época e extensão do período de convivência (PITELLI, 1985).

O período crítico de controle das plantas daninhas é o intervalo durante o ciclo da cultura em que ela deve ser mantida no limpo para que não ocorra perda de produção. Esse período é o resultado de dois diferentes períodos: (a) período anterior à interferência (PAI), ou seja, período a partir da emergência da cultura em que ela pode conviver com as plantas daninhas sem que haja perda de produtividade e (b) período total de prevenção à interferência das plantas daninhas (PTPI), que é o período a partir da emergência da cultura em que ela deve ser mantida no limpo para que possa manifestar plenamente seu potencial produtivo. O período que coincide com o limite 
superior do PAI e PTPI é o período crítico de prevenção à interferência das plantas daninhas (PCPI) (PITELLI \& DURIGAN, 1984).

Com a introdução das novas cultivares, informações sobre os períodos de interferência das plantas daninhas na cultura do amendoim vêm sendo geradas. Contudo, observam-se variação entre esses valores, mostrando assim a necessidade de trabalhos como este, seja para confirmar informações já existentes ou gerando novas informações.

Pelo relatado, esta pesquisa teve por objetivo avaliar os efeitos da diminuição do espaçamento entrelinhas e da densidade populacional do amendoim rasteiro, cultivar Runner IAC 886 sobre o período anterior de interferência (PAI) das plantas daninhas e produtividade da cultura. 


\section{REVISÃO BIBLIOGRÁFICA}

O amendoim é originário da América e utilizado como planta domesticada em período remoto, por civilizações indígenas sul-americanas. Achados arqueológicos no Peru, onde sementes de amendoim foram analisadas pelo método do carbono 14, permitiram fixar a idade em torno de 3.800 anos. As espécies do gênero Arachis, ao qual pertence o amendoim cultivado, em número de 50 , ocorrem no continente americano, principalmente no Brasil, Paraguai, Argentina, Bolívia e Uruguai (HAMMONS, 1973). Segundo o autor, até a época pré-colombiana o amendoim era cultivado apenas na América do Sul, América Central e parte do México e após o início da exploração dos portugueses e espanhóis, foi levado para a África e Ásia, onde apresenta, hoje, grande importância socioeconômica, constituindo, em alguns casos, a principal fonte protéica e calórica alimentar das populações mais pobres dessas regiões.

O amendoim é uma eudicotiledônea, herbácea, anual, pertencente a família Leguminosae, e ao gênero Arachis. Dentre as inúmeras espécies conhecidas a mais importante é Arachis hypogaea L., que é subdividida em três grupos botânicos de acordo com a morfologia da planta. No Brasil dois tipos botânicos, o Valência e o Virgínia, são mais comercialmente cultivados. O grupo Spanish tem pouca expressão econômica no país (SANTOS et al., 1997).

O amendoim tem importância significativa devido a grande amplitude de utilização. O grão pode ser consumido "in natura", torrado ou depois de algum processo industrial, na fabricação de pasta, manteiga, óleo, doces e confeitos (SANTOS et al., 1997). Seus sub-produtos também têm relevante importância como o óleo para a fabricação de tintas e para a indústria farmacêutica (GODOY, et al, 2005) e o farelo rico em proteína pode ser destinado a alimentação animal (CARNEIRO, 2006).

SANTOS et al. (2005) estimaram que $80 \%$ das áreas ocupadas com amendoim são provenientes de reforma de canaviais. Uma outra utilização da cultura é a rotação com pastagens, na integração lavoura-pecuária, na Região Oeste do Estado de São Paulo (CRUSCIOL \& SORATTO, 2007). 
Para muitos produtores, especialmente os das regiões centro-leste e centrooeste do estado de São Paulo, a cultura é a principal ou até mesmo a única fonte de renda. Estas regiões se destacam como maiores produtoras. Os produtores paulistas são responsáveis por aproximadamente $77 \%$ da produção nacional (AGRIANUAL, 2009).

A produtividade da cultura aumentou significativamente nos últimos anos, passando de $1.920 \mathrm{~kg} \cdot \mathrm{ha}^{-1}$ na safra $2000 / 2001$ para $2.656 \mathrm{~kg} \cdot \mathrm{ha}^{-1}$ na safra $2007 / 2008$, o que representa um aumento de 38\% (AGRIANUAL, 2009). A área plantada teve um aumento de $12 \%$, enquanto a produção passou de $196.700 \mathrm{~kg}$ para $305.793 \mathrm{~kg}$ no mesmo período, o que representa $55 \%$ de acréscimo, expressando uma contradição com os outros produtores mundiais que deixaram de produzir 2,5\% (AGRIANUAL, 2009). Esse fato é favorável ao Brasil para se firmar como grande exportador do grão com qualidade.

Alguns fatores influenciaram esse aumento de produção e produtividade, como a introdução de máquinas modernas, que deram ao produtor a possibilidade de aumentar a área plantada e diminuir as perdas nas operações do arranquio, inversão e colheita. Outro fator foi a introdução de novas cultivares de porte rasteiro, habito de crescimento prostrado e com maior potencial produtivo, sendo que a que mais de destacou foi a IAC Runner 886.

A cultivar IAC Runner 886 resultou da seleção de uma população de plantas oriundas do antigo cultivar americano, "Florunner". Apresenta como características agronômicas ciclo de aproximadamente 130 dias, hábito de crescimento rasteiro, é sensível às principais doenças da parte aérea, exigindo um rigoroso programa de pulverizações. Apresenta vagens com duas sementes e com dormência de sementes, sementes grandes com tegumento das sementes de coloração rosada, com faixa de massa de 50 a $70 \mathrm{~g}$ por 100 sementes e possui um alto potencial produtivo, chegando a atingir, em condições favoráveis de clima, fertilidade do solo e controle de doenças, 6.500 kg.ha-1. Apresenta, ainda, boa tipificação dos grãos para o mercado de exportação (GODOY et al., 2005). 
Fatores de natureza abiótica e biótica afetam a produção das culturas, incluindo a do amendoim. Dentre os fatores abióticos, pode-se citar a disponibilidade de água, nutrientes, $\mathrm{pH}$ do solo, luminosidade, e outros. Os fatores bióticos são aqueles decorrentes da ação dos seres vivos (PITELLI \& MARCHI, 1991). A interferência das plantas daninhas, que se refere ao conjunto de ações que recebe uma determinada cultura ou atividade do homem, em decorrência da presença de plantas daninhas num determinado ambiente nas culturas, é considerada um fator biótico (PITELLI, 1985).

O maior sucesso das plantas daninhas na interferência deve-se à maior agressividade em relação às plantas cultivadas, estas que normalmente são selecionadas geneticamente para uma alta produtividade e uniformidade de características morfológicas e agronômicas. Com isso, sua variabilidade genética é reduzida e, normalmente, perdem muito a agressividade, estando assim mais sensíveis às adversidades do meio (BLANCO, 1972; PITELLI et al., 1981).

BLEASDALE (1960) foi o primeiro a esquematizar os fatores que podem afetar o grau de interferência de uma planta infestante com uma cultura. Esse esquema foi posteriormente modificado por BLANCO (1972) e depois por PITELLI (1985), que propôs que tais fatores estão relacionados à comunidade infestante (composição específica, densidade e distribuição), à cultura (espaçamento, densidade e cultivar) e ao ambiente (solo, clima e práticas de manejo adotadas).

O grau de interferência também é afetado pela época e duração do período de convivência entre a cultura e as plantas daninhas (PITELLI, 1985). Normalmente este se expressa pelo decréscimo percentual da produção de frutos ou sementes da parcela em convivência com as plantas daninhas (no mato), em relação à parcela no limpo durante todo o ciclo da cultura.

Trabalhos de pesquisa com a cultura do amendoim relatam grande amplitude nestes resultados, como perdas de $50 \%$ na produção (HAMMERTON, 1974; PITELLI, 1980; YADAV et al., 1984; MARTINS \& PITELLI, 1994; PITELLI et al., 2002) e mais de 50\% (BIANCO, 1978; DRENAN \& JENNINGS, 1977; DIAS et al., 2005; NEPOMUCENO et al., 2005; AGOSTINHO et al., 2006; NEPOMUCENO et al., 2006; SOUZA JUNIOR, 
2006; DIAS et al., 2005). Devido a essa grande variação de resultados, é difícil extrapolar os dados obtidos para diferentes localidades e cultivares.

A época a partir da semeadura ou a partir da emergência da cultura, durante o qual esta pode conviver com as plantas daninhas sem que ocorram reduções significativas na sua produtividade foi denominada por PITELLI \& DURIGAN (1984) de período anterior à interferência (PAI). Os resultados obtidos para este período são bastante variados, o que é normal, devido aos vários fatores que intervêm no grau de interação (BLANCO, 1972).

Alguns valores observados para o PAI no Brasil foram: 56 dias (PITELLI 1980; PANSANI, 1983), 42 dias (PACHECO, 1980), 14 dias (KASAl et al. 1997), 45 a 59 dias (PITELLI et al. 2002), 6, 14, 10, 11 e 20 dias, para as cultivares Caiapó, Runner Tégua, ST Tatú, IAC-22 e IAC-1057, respectivamente (AGOSTINHO et al. 2006). NEPOMUCENO et al. (2007) constataram que para a semeadura em inicio de novembro e dezembro os PAl's foram de 28 e 33 dias, respectivamente.

$\mathrm{Na}$ literatura existe uma grande variação nos valores do Período Crítico de Prevenção da Interferência das plantas daninha (PCPI): de 23 até 102 dias, como podese observar nos trabalhos de NEPOMUCENO (2006) e SOUZA JUNIOR (2006).

PITELLI (2006) denominou, ainda, outro período: período anterior à interferência subseqüente (PAIS), sendo este o período compreendido entre a primeira medida de controle das plantas daninhas até o momento em que um novo fluxo dessas plantas passe a afetar a produtividade da cultura. Este é mais importante em casos de valores baixos de PAl e/ou quando o método de controle das plantas daninhas não apresente residual.

O período de interferência das plantas daninhas pode ser estudado isoladamente ou em associação a outros fatores que também alteram o grau de interferência das plantas daninhas, como a época e localidade de semeadura (NEPOMUCENO et al., 2006), comunidade infestante (CARDOZO et al., 2006), cultivar (AGOSTINHO et al. 2006), densidade da cultura e espaçamento entre linhas (DIAS et al., 2009). Como esses fatores são passives de serem alterados, este tipo de estudo, além de indicar a 
época em que as plantas daninhas efetivamente devem ser controladas, possibilita o uso de medidas culturais de controle que possam favorecer a cultura.

A redução de espaçamento entrelinhas é um dos métodos culturais de controle das plantas daninhas que visa aumentar a competitividade da cultura e, conseqüentemente, reduzir a interferência das plantas daninhas. FISCHER \& MILES (1973) simularam os processos de interferência entre plantas daninhas e culturas. Esses modelos indicaram ser possível influenciar o resultado final da competição a favor da cultura com a utilização de arranjos espaciais eqüidistantes, os quais podem ser obtidos pela redução do espaçamento entrelinhas.

CENTURION et al. (2005) demonstraram que para a cultivar IAC Runner 886 diferentes densidades e espaçamentos não influenciaram no crescimento da haste principal e número de ramificações das plantas. Quando analisadas a produção, rendimento e tamanho dos grãos, os autores constataram que não houve diferença significativa para diferentes espaçamentos e densidades. Nas menores densidades houve aumento do número médio de vagens e seu peso também foi maior, o que sugere que esta cultivar pode possibilitar uma redução da densidade, o que implicará em redução de custos, sem, no entanto perder produção. Contudo, ROMANINI JUNIOR et al. (2006) relataram que para o espaçamento de $90 \mathrm{~cm}$, densidades de 15 e 6 plantas por metro proporcionaram menor produção, quando comparadas as densidades de 18 , 12 e 9 , o que contradiz trabalhos anteriores.

Com o advento da utilização dos arrancadores/invertedores mecânicos na colheita do amendoim, cujos sulcadores que promovem o arranquio estão distanciados em 0,90 m, tem-se atualmente utilizado o espaçamento entrelinhas de 0,90 m para as cultivares, visando viabilizar a colheita mecanizada (FERNANDES, 2004). Em relação à densidade de plantas na linha, reduziu-se para 12 a 15 plantas por metro, o que resulta em populações de 133 mil a 166 mil plantas por hectare (TASSO JUNIOR et al., 2004), correspondendo a uma população menor em relação à recomendada por GODOY et al. (1986) e LASCA (1986) e a utilizada rotineiramente pelos agricultores em cultivares de porte ereto e antes da adoção da colheita mecanizada. 
Diversos pesquisadores (KNAKE, 1972; MAUN, 1977; XAVIER \& PINTO, 1988; BRAZ \& DURIGAN, 1993) verificaram que o sombreamento precoce, determinado pelo fechamento da cultura, prejudica o desenvolvimento das plantas daninhas e favorece a cultura na competição pelos fatores limitantes do meio. O sombreamento prejudica também a germinação de sementes de plantas daninhas, já que a maioria delas é fotoblástica positiva.

NAKAGAWA et al. (1994), em estudos realizados com a cultivar Tatu Vermelho, semeada no espaçamento entrelinhas de $0,60 \mathrm{~m}$ e em densidades de $5,8,11,14,17$, 20, 23 e 26 plantas por metro, verificaram as menores produções por planta nas maiores densidades; entretanto, devido à maior população de plantas, as maiores produtividades foram as obtidas.

Estudando os efeitos do espaçamento entrelinhas do amendoim sobre o acúmulo de massa seca de Desmodium tortuosum e Senna obtusifolia, BUCHANAN \& HAUSSER (1980), verificaram que os menores valores de crescimento, para ambas as plantas, foram observados no espaçamento mais reduzido.

COLVIN et al. (1985), comparando o acúmulo de matéria, na comunidade infestante, observaram valores menores para o amendoim semeado em fileiras duplas com $18 \mathrm{~cm}$ entre elas e com outra fileira espaçadas de $56 \mathrm{~cm}$, quando comparado com o sistema convencional de $91 \mathrm{~cm}$ entrelinhas simples.

Segundo DIAS et al. (2009), uma redução de $10 \mathrm{~cm}$ no espaçamento entre fileiras, de 90 para $80 \mathrm{~cm}$, não diminuiu a infestação de plantas daninhas, mas favoreceu a produtividade da cultura. As plantas daninhas causaram perdas de produção acima de $80 \%$ quando a cultura conviveu com estas durante todo o seu ciclo, independentemente do espaçamento entre fileiras. Segundo este autor, para uma perda aceitável de $5 \%$ na produção, a cultivar IAC Runner 886 não pode conviver com as plantas daninhas por mais de 27 dias no espaçamento entrelinhas de $80 \mathrm{~cm}$ e 35 dias para o espaçamento de $90 \mathrm{~cm}$.

Conforme mencionado anteriormente, outro fator que pode influenciar na competição da cultura com as plantas daninhas e a sua produção é a densidade de plantas. NAKAGAWA et al. (1994) verificaram maiores produtividades com densidades 
maiores de plantas por metro em solos de alta fertilidade. Já, em solos de média a baixa fertilidade para se obter maiores produtividades necessitou-se de menor densidade, de 16 plantas por metro. Solos arenosos, segundo GODOY et al. (2005), são os melhores para a cultura do amendoim, pois favorecem a penetração dos ginóforos e facilitam a colheita.

NAKAGAWA et al. (1983) sugerem que a população de plantas podem interferir na produtividade, afetando diretamente os componentes de produção. Para a cultura do amendoim, segundo o mesmo autor, a fixação desta população pode variar em função da cultivar, da época de semeadura, da adubação e da região de cultivo.

Segundo COX \& REID (1965) população de plantas de uma cultura é definida teoricamente através da combinação de diferentes espaçamentos e densidades de semeadura. As cultivares de amendoim apresentam hábitos de crescimento diferentes, portanto o arranjo espacial será dependente do tipo botânico. Genótipos de porte ereto freqüentemente são cultivados com altas populações, pois utilizam menor área para desenvolvimento dos frutos em relação a materiais do tipo ramador, muito embora possam demonstrar resposta na produção de vagens quando a semeadura é adensada.

GODOY et al. (2005) recomendam o espaçamento médio entrelinhas de 0,80 a $0,90 \mathrm{~m}$, deixando-se cair 14 a 15 sementes por metro. As cultivares rasteiras garantem seu potencial produtivo com um menor número de plantas por área quando comparados aos amendoins de porte ereto. CENTURION et al. (2005) e CENTURION et al. (2005 a), estudando diferentes espaçamentos entrelinhas e diferentes densidades de plantas na linha, verificaram que a produtividade, rendimento de grãos, tamanho dos grãos e o crescimento da planta foram semelhantes nos vários tratamentos testados para a cultivar rasteira IAC Runner 886. Os resultados podem ser considerados bastante favoráveis, e permitem a flexibilidade de escolha necessária ao sistema produtivo de cada propriedade agrícola. 


\section{MATERIAL E MÉTODOS}

O experimento foi instalado e conduzido na Fazenda de Pesquisa, Ensino e Produção da FCAV/UNESP, localizada no município de Jaboticabal, São Paulo, Brasil, na latitude de $21^{\circ} 15^{\prime} 22^{\prime \prime}$ Sul e longitude de 48¹8'58" Oeste. Segundo a classificação internacional de Koeppen, o clima da região é do tipo Cwa, em que, na época das águas predominam as chuvas de verão, com inverno relativamente seco. A temperatura média do mês mais quente é superior a $22^{\circ} \mathrm{C}$ e a do mês mais frio inferior a $18^{\circ} \mathrm{C}$, com precipitação média anual de $1440 \mathrm{~mm}$.

\subsection{DESCRIÇÃO E PREPARO DO SOLO}

O solo da área experimental foi classificado, segundo ANDRIOLI \& CENTURION (1999), como um Latossolo Vermelho eutrófico típico, de textura média, topografia suavemente ondulada, condições de boa drenagem e características químicas de 5,5 para $\mathrm{pH}$ em $\mathrm{CaCl}_{2} ; 15 \mathrm{~g} \mathrm{dm}^{-3}$ de matéria orgânica; $49 \mathrm{mg} \mathrm{dm}^{-3}$ de $\mathrm{P}$ (resina); 1,2; 22; 15 ; 16; 38,2 e 54,2 mmol $_{\mathrm{c}} \mathrm{dm}^{-3}$ de $\mathrm{K}, \mathrm{Ca}, \mathrm{Mg}, \mathrm{H}+\mathrm{Al}$, SB e CTC, respectivamente e $\mathrm{V} \%$ de 73. A coleta do solo para análise foi feita anterior ao início do experimento. O sistema de preparo do solo empregado foi o convencional, por meio de uma gradagem pesada seguida de duas gradagens niveladoras.

\subsection{CULTIVAR}

A cultivar de amendoim utilizada foi a IAC RUNNER 886, obtida juntamente a Cooperativa dos Plantadores de Cana da Zona de Guariba (COPLANA). Suas principais características, segundo GODOY (2002), estão descritas na Tabela 1. 
Tabela 1. Principais características da cultivar IAC Runner 886 (GODOY, 2002).

\begin{tabular}{ll}
\hline Características & \multicolumn{1}{c}{ IAC Runner 886 } \\
\hline Grupo & Virgínia \\
Ciclo & 120 a 130 dias \\
Hábito de crescimento & Rasteiro \\
Produtividade máxima & $6.500 \mathrm{~kg} \mathrm{ha}^{-1}$ \\
Renda & 18 a $20 \mathrm{~kg} \mathrm{saca}^{-1}$ \\
Número de sementes por vagem & 2 \\
Dormência & Acentuada \\
Cor do tegumento & Rosada \\
Qualidade química (O/L) & 1,6 a 1,8 \\
\hline \hline
\end{tabular}

\subsection{DELINEAMENTO E TRATAMENTOS EXPERIMENTAIS}

Para atender ao objetivo do trabalho, foram instalados dois grupos de tratamentos, nos espaçamentos de 0,60 $\mathrm{m}$ e de 0,90 m.

Para cada espaçamento entrelinhas, o delineamento experimental utilizado foi o de blocos casualizados com os tratamentos dispostos em parcelas subdivididas. As parcelas corresponderam as densidades populacionais $\left(5,10\right.$ e 15 plantas $\left.\mathrm{m}^{-1}\right)$ e as subparcelas aos períodos de convivência da cultura com a comunidade infestante $(0,15$, $30,45,60,75,90,105$ e 120 dias após a emergência do amendoim), totalizando 27 tratamentos em três repetições.

As subparcelas experimentais foram constituídas por quatro linhas de semeadura com cinco metros de comprimento. Como área útil foram consideradas as duas fileiras centrais da cultura, desprezando-se $0,5 \mathrm{~m}$ das extremidades.

\subsection{SEMENTES E SEMEADURA}

As sementes foram tratadas com o inseticida tiametoxam e o fungicida thiram, na ocasião da semeadura foi adicionado grafite em pó para minimizar a quebra dos grãos 
e proporcionar melhor distribuição nas linhas. A semeadora utilizada foi da marca Jumil, de quatro linhas de semeadura espaçadas em 0,60 ou $0,90 \mathrm{~cm}$, de acordo com o tratamento. Em cada linha de semeadura, foram depositadas 30 sementes por metro. Aos sete dias após a emergência da plantas, foi realizado o desbaste, deixando 5,10 ou 15 plantas por metro, de acordo com o tratamento. A população obtida por hectare pode ser vista na Tabela 2 .

Tabela 2. População da cultura do amendoim em função do espaçamento e da densidade de plantas. $\mathrm{m}^{-1}$. Jaboticabal, SP, 2007/2008

\begin{tabular}{ccc}
\hline \hline & \multicolumn{2}{c}{ Espaçamento } \\
Número de plantas.m- ${ }^{1}$ & $0,60 \mathrm{~m}$ & $0,90 \mathrm{~m}$ \\
5 & 83.333 & 55.555 \\
10 & 166.666 & 111.111 \\
15 & 250.000 & 166.666 \\
\hline \hline
\end{tabular}

A semeadura foi realizada em 23 de novembro de 2007 e o desbaste de plantas, para obter a densidade desejada, em 15 de dezembro do mesmo ano. A adubação da cultura foi realizada concomitantemente com a semeadura, utilizando-se $200 \mathrm{~kg}^{\mathrm{ha}} \mathrm{ha}^{-1} \mathrm{da}$ formulação 2-20-20 (NPK). A quantidade de adubo utilizada foi calculada segundo o Boletim 100 do IAC.

\subsection{TRATAMENTO FITOSSANITÁRIO}

No decorrer do período experimental, foram realizadas sete pulverizações de inseticidas e fungicidas, como prevenção e controle de tripes (Enneohtrips flavens Moulton) e lagarta-do-pescoço-vermelho (Stegasta bosquella Chambers); além dos fungos, como mancha castanha (Cercospora arachidicola Horti), mancha preta (Cercosporidium personatum (Berk \& Curtis) Ellis \& Everhart) e verrugose (S phaceloma arachidis Bit \& Jenk). As pulverizações foram feitas de para a prevenção de doenças e para o controle do ataque de insetos. As doses seguiram as recomendações do 
fabricante de cada produto. As datas, produto e dose de aplicação se encontram na Tabela 3.

Tabela 3. Nome comercial, nome químico, dose e data de aplicação dos produtos fitossanitários empregados no decorrer do período experimental. Jaboticabal, SP, 2007/2008.

\begin{tabular}{|c|c|c|c|c|c|}
\hline \multirow{2}{*}{$\begin{array}{l}\text { Número } \\
\text { de } \\
\text { pulveriza } \\
\text { ções }\end{array}$} & \multirow{2}{*}{$\begin{array}{l}\text { Nome } \\
\text { Comercial }\end{array}$} & \multirow{2}{*}{ Nome Químico } & \multicolumn{2}{|c|}{ Dose } & \multirow{2}{*}{ Data } \\
\hline & & & pc & la & \\
\hline \multirow{3}{*}{1} & Lorsban $480 \mathrm{BR}$ & clorpirifós & 0,6 & \multirow{3}{*}{$\begin{array}{c}0,480 \\
0,825 \\
0,220+0,110\end{array}$} & 19/12/2007 \\
\hline & Bravonil Ultrex & cloratolonil & 2,0 & & $19 / 12 / 2007$ \\
\hline & Engeo & cipermetrina+tiametoxam & 0,25 & & $19 / 12 / 2007$ \\
\hline \multirow[t]{2}{*}{2} & Tamaron BR & Metamidafós & 0,5 & 0,600 & $04 / 01 / 2008$ \\
\hline & Isotalonil & Clorotalonil & 2,5 & 0,750 & 04/01/2008 \\
\hline \multirow[b]{2}{*}{3} & Engeo & \multirow{2}{*}{$\begin{array}{l}\text { cipermetrina+tiametoxam } \\
\text { epoxiconazol } \\
\text { piraclostrotbina }\end{array}$} & 0,3 & $0,220+0,110$ & $18 / 01 / 2008$ \\
\hline & Opera & & 0,6 & $0,050+0,133$ & $18 / 01 / 2008$ \\
\hline \multirow[b]{2}{*}{4} & Tamaron BR & \multirow{2}{*}{$\begin{array}{l}\text { Metamidafós } \\
\text { clorotalonil }+ \text { tiofanat- } \\
\text { metilíco }\end{array}$} & 0,5 & 0,600 & $01 / 02 / 2006$ \\
\hline & Cerconil SC & & 2,5 & $0,350+0,140$ & $01 / 02 / 2006$ \\
\hline \multirow{4}{*}{5} & Bravonil & \multirow{4}{*}{$\begin{array}{l}\text { Cloratalonil } \\
\text { epoxiconazol } \\
\text { piraclostrotbina } \\
\text { alfacipermetrina }\end{array}$} & & & $15 / 02 / 2008$ \\
\hline & & & 07 & $\begin{array}{c}0,825 \\
0,050+0133\end{array}$ & $15 / 02 / 2008$ \\
\hline & Opera & & 015 & 0,100 & \\
\hline & Fastac 100 & & & & $15 / 02 / 2008$ \\
\hline \multirow{5}{*}{6} & Opera & epoxiconazol & 07 & $0050+0133$ & $27 / 02 / 2008$ \\
\hline & & piraclostrotbina & & & \\
\hline & Tamaron BR & metamidofós & 0,5 & 0,600 & $27 / 02 / 2008$ \\
\hline & Bravonil & clorotalonil & 3,0 & 0,825 & $27 / 02 / 2008$ \\
\hline & Bravonil & cloratolonil & 3,0 & 0,825 & $12 / 03 / 2008$ \\
\hline 7 & Tamaron BR & cetamidofós & 0,6 & 0,600 & $12 / 03 / 2008$ \\
\hline
\end{tabular}




\subsection{AVALIAÇÕES}

\subsubsection{COMUNIDADE INFESTANTE}

Para caracterização da comunidade infestante, nos tratamentos em que a cultura conviveu com as plantas daninhas, foram lançados ao final de cada período de convivência, ao acaso, dois quadrados amostrais de 0,25 $\mathrm{m}^{2}$. As plantas daninhas presentes no quadro foram coletadas, identificas, contadas, acondicionadas em sacos de papel, levadas as estufa de circulação a $70^{\circ} \mathrm{C}$ para secagem e depois pesadas. Após realizado o levantamento nas áreas amostrais, foi realizada a capina manual de toda a parcela, que permaneceu limpa até a colheita.

Os dados de densidade e a massa seca acumulada da parte aérea, referentes à comunidade infestante, assim como os das espécies de plantas daninhas mais freqüentes na área, foram extrapolados para número de plantas e quilogramas de massa seca por $\mathrm{m}^{2}$, respectivamente.

Com os dados obtidos em cada amostragem foi realizada a análise fitossociológica da comunidade infestante, segundo procedimento descrito por MUELLER-DOMBOIS \& ELLEMBERG (1974), sendo determinadas, para cada espécie, a freqüência relativa, a densidade relativa, a dominância relativa e a importância relativa.

A densidade relativa reflete a relação porcentual do número de indivíduos de uma população em relação ao número total de indivíduos da comunidade infestante.

A densidade relativa das populações foi medida pela fórmula:

De.R. $=\frac{\mathrm{Ni}}{\mathrm{Nt}}$, em que

- De.R. = densidade relativa;

- $\mathrm{Ni}$ = número de indivíduos da uma população;

- $\mathrm{Nt}=$ Número total de indivíduos da comunidade infestante 
A densidade relativa das populações é uma medida da relevância da população em termos do número de indivíduos.

A freqüência de uma população é a porcentagem de amostras em que pelo menos um indivíduo da espécie esteve presente. A freqüência relativa reflete a relação porcentual da freqüência de uma população em relação à somatória das freqüências de todas as populações.

A freqüência das populações foi calculada pela fórmula:

$$
\mathrm{Fr}=\frac{\mathrm{NAi}}{\mathrm{NAt}} \times 100, \text { em que }
$$

- $\operatorname{Fr}=$ freqüência

- $\quad \mathrm{NAi}$ = número de amostras em que ocorre a espécie i;

- $\quad \mathrm{NAt}=$ número total de amostras efetuadas

A freqüência relativa das populações foi calculada pela fórmula:

Fr.R $=\frac{\text { Fri }}{\sum_{i=11}^{n} F r i} \times 100$, em que

- Fr.R.= freqüência relativa;

- $\quad F r i=$ freqüência de uma determinada população.

A freqüência relativa é uma medida de relevância da população em termos de ocupação (distribuição) da área de estudo.

A dominância relativa de uma população de planta daninha, para os propósitos do presente trabalho, pode ser definida como a relação percentual entre a biomassa acumulada por uma população e a biomassa total da comunidade infestante.

A dominância relativa foi calculada pela fórmula: 
$D \circ \cdot R=\frac{B S i}{\sum_{i=1}^{n} B S i} \times 100$, em que

- Do.R. = dominância relativa;

- $\mathrm{BSi}=$ peso da massa seca de uma determinada população

A dominância relativa é uma medida da relevância de população em termos da biomassa seca acumulada ou do recrutamento de recursos do meio.

Índice de valor de importância das populações trata-se de um índice complexo em que são considerados o número de indivíduos (De.R), a distribuição dos indivíduos na área de estudo (Fr.R) e a biomassa seca acumulada pela população em questão.

O índice de valor de importância das populações foi calculado pela fórmula:

$I V I=D e . R+F r . R+D o \cdot R$

- $\quad \mathrm{IVI}=$ índice de valor de importância;

- De.R. = densidade relativa;

- Fr.R.= frequência relativa;

- Do.R. = dominância relativa;

A importância relativa de uma população pode ser definida como a participação porcentual do IVI de uma espécie em relação ao somatório do IVIs de todas as populações da comunidade infestante.

A importância relativa das populações foi calculada pela fórmula:

$I R=\frac{|V| i}{\sum_{i=1}^{n}|V| i} \times 100$, em que

- $\quad \mathrm{IR}=$ importância relativa;

- $\quad \mathrm{IVI}=$ índice de valor de importância; 
A importância relativa é uma medida da relevância da população considerando o conjunto da densidade e distribuição dos indivíduos e a biomassa acumulada.

\subsubsection{CULTURA}

Aos 147 dias após a semeadura do amendoim, dia 21 de abril de 2008, foram realizados 0 arranquio e inversão das plantas na área útil de cada parcela, com a utilização de um arrancador e invertedor marca Santal de duas linhas. As plantas foram deixadas no campo para secagem ao sol e posterior colheita mecanizada. A colheita foi realizada no dia 29 de maio e para tal operação foi utilizada uma colhedora modelo Double Master, marca Miac, de uma linha.

$\mathrm{Na}$ ocasião da colheita, as vagens do amendoim foram acondicionadas em sacos de plástico e depois em sacos de papel e deixados em barracão coberto até atingirem a umidade igual ou menor que $8 \%$, quando foi determinada sua massa. Para a determinação da massa das vagens colhidas utilizou-se uma balança digital eletrônica com precisão de 0,01 g. Foi determinada também a umidade dos grãos com auxílio do equipamento MOTOMCO, mod. 919 ES, presente nas instalações da Coplana. Os grãos são colocados no aparelho e daí é determinada a umidade.

\subsubsection{ANÁLISE DOS RESULTADOS}

Os resultados de produtividade foram processados separadamente dentro de cada grupo, sendo submetidos à análise de regressão (programa estatístico Microcal Origin 6.1), segundo o modelo sigmoidal de Boltzman:

$$
Y=A_{2}+\left[\left(A_{1}-A_{2}\right) /(1+\exp (X-X o) / d x)\right]
$$

em que, $Y$ é a produtividade de amendoim, em kg ha-1, obtida conforme os períodos de convivência; $x$, o limite superior do período de convivência (dias); $A_{2}$, a produção mínima obtida nas parcelas mantidas no mato durante todo o ciclo; $\left(A_{1}-A_{2}\right)$, a perda de produção; $x_{0}$, o limite superior do período de convivência, que corresponde ao valor 
intermediário entre a produção máxima e a mínima; e dx, o parâmetro que indica a velocidade de perda ou ganho de produção (tangente no ponto $x_{\circ}$ ).

Os limites dos períodos anteriores de interferência foram determinados tolerando-se perdas máximas de produção de $5 \%$ em relação àquela obtida nas parcelas mantidas no limpo durante todo o ciclo. 


\section{RESULTADOS E DISCUSSÃO}

\subsection{Comunidade infestante}

Após os levantamentos feitos na comunidade infestante da área experimental, constatou-se que as plantas daninhas presentes, de acordo com sua família, nome cientifico, popular e código internacional, segundo a International W eed Society foram:

a) Família Amaranthaceae:

- Alternanthera tenella Colla (Apaga-fogo) ALRTE

- Amaranthus viridis L. (Caruru-de-mancha) AMAVI

b) Família Asteraceae (Compositae)

- Acanthospermum australe (Loefl.) O. Kuntze (Carrapicho-rasteiro) ACNAU

- Acanthospermum hispidum DC. (Carrapicho-de-carneiro) ACNHI

- Bidens pilosa L. (Picão-preto) BIDPI

- Blainvillea rhomboidea Cass. (Erva-palha) BLARH

- E milia fosbergii Nicolson (Falsa-serralha) EMISO

- Xanthium strumarium L. (Carrapichão) XANSI

- Partheniun hysterophorus L. (Losna-branca) PTNHY

- Agetarum conyzoides L. (Mentrasto) AGECO

- Tridax procumbens L. (Erva-de-touro) TRQPR

c) Família Brassicaceae (Cruciferae)

- Raphanus raphanistrum L. (Nabiça) RAPRA

d) Família Commelinaceae

- Commelina benghalensis L. (Trapoeraba) COMBE

e) Família Convolvulaceae

- Ipomoea triloba L. (Dammer) O' Don (Corda-de-viola) IPOTR 
f) Família Cyperaceae

- Cyperus rotundus L. (Tiririca) CYPRO

g) Família Euphorbiaceae

- Euphorbia heterophylla L. (Leiteiro) EPHHL

h) Família Fabaceae (Leguminosae)

- Indigofera hirsuta L. (Anileira) INDHI

- Senna obtusifolia (Fedegoso) CASOB

- Desmoduim torturosum (Pega-pega) DEDTO

i) Família Malvaceae

- Sida rhombifolia L. (Guanxuma) SIDRH

j) Família Poaceae (Gramineae)

- Brachiaria plantaginea (Link) Hitchc (Capim-marmelada) BRAPL

- Cenchrus echinatus L. (Capim-carrapicho) CCHEC

- Digitaria sp. Willd. (Capim-colchão) DIGSS

- Digitaria insularis (L.) Fedde (capim-amargoso) DIGIN

- Eleusine indica (L.) Gaertn. (Capim-pé-de-galinha) ELEIN

- Panicum maximum Jacq. (Capim-colonião) PANMA

- Echinochloa colonum (L.) Link. (Capim-arroz) ECHCO

I) Família Portulacaceae

- Portulaca oleracea L. (Beldroega) POROL

m) Família Rubiaceae

- R ichardia brasiliensis Gomes ( Poaia-branca) RCHBR

- Spermacoce latifolia Aubl. ( Erva-quente) BOILF 
n) Família Solanaceae

-P hysalis angulata L. (Balãozinho) PHYAN

Observou-se durante todo o período experimental uma comunidade infestante diversificada, tanto em número de espécies, 31 no total, quanto na quantidade de famílias, treze. Dentre essas famílias, três são monocotiledôneas e o restante são de eudicotiledôneas. A família com maior número de espécies foi Poaceae, com sete espécies.

As famílias de plantas daninhas monocotiledôneas de maior importância no Brasil são seis, dentre as quais pode se destacar a Poacae com mais de 60 espécies. Já as eudicotiledôneas apresentam um número maior de famílias, sendo mais de 40 consideradas de importância econômica (DEUBER, 2003).

A densidade total de plantas daninhas durante todo o ciclo da cultura e a massa seca desses indivíduos no espaçamento de 0,60 $\mathrm{m}$ e 0,90 $\mathrm{m}$ para as densidade de 5 , 10 e 15 plantas podem ser visualizadas nas Figuras 1, 2, 3 e 4.

Aos 15 dias após a emergência da cultura (DAE), no espaçamento de 0,60 m de entrelinha da cultura do amendoim, na densidade de semeadura de 5 plantas. $\mathrm{m}^{-1}$, a comunidade infestante apresentou uma densidade de 44 plantas. $\mathrm{m}^{-2}$. A densidade máxima da comunidade infestante foi observada aos 30 DAE (88 plantas. $\mathrm{m}^{-2}$ ) e, na ocasião da colheita, aos 120 DAE a densidade das plantas daninhas foi de apenas 4 plantas. $\mathrm{m}^{-2}$ (Figura 1A). Desta forma, o valor médio da densidade da comunidade infestante durante todo o ciclo da cultura foi de 33 plantas. $\mathrm{m}^{-2}$.

$\mathrm{Na}$ densidade de 10 plantas. $\mathrm{m}^{-1}$ da cultura, a densidade inicial da comunidade infestante foi de 49 plantas. $\mathrm{m}^{-2}$ com maior densidade de plantas daninhas aos 75 DAE (123 plantas. $\mathrm{m}^{-2}$ ). Na colheita, houve redução da densidade da comunidade infestante, com 3 plantas. $\mathrm{m}^{-2}$ (Figura 1B), resultando em densidade média de 39 plantas. $\mathrm{m}^{-2}$ no decorrer do período experimental.

$\mathrm{Na}$ densidade de 15 plantas. $\mathrm{m}^{-1}$, no inicio do ciclo da cultura (15DAE), a densidade inicial da comunidade infestante foi de 56 plantas. $\mathrm{m}^{-2}$., com maior densidade 
de plantas daninhas observada aos 45 DAE (105 plantas. $\mathrm{m}^{-2}$ ) e na colheita do amendoim, a densidade foi reduzida para 5 plantas. $\mathrm{m}^{-2}$ (Figura $1 \mathrm{C}$ ), resultando em valor médio da densidade das plantas daninhas, durante o ciclo da cultura, de 38 plantas. $\mathrm{m}^{-2}$.

O espaçamento de $0.90 \mathrm{~m}$, na densidade de 5 plantas. $\mathrm{m}^{-1}$ da cultura, apresentou, inicialmente, densidade de 20 plantas $\mathrm{m}^{-2}$ e o valor máximo ocorreu aos 30 DAE (134 plantas. $\mathrm{m}^{-2}$ ); já na colheita, a densidade foi de 11 plantas. $\mathrm{m}^{-2}$ (Figura 2A). Durante todo o ciclo da cultura, a densidade média foi de 33 plantas. $\mathrm{m}^{-1}$.

$\mathrm{Na}$ densidade de 10 plantas. $\mathrm{m}^{-1}$ a densidade inicial de plantas daninhas foi de 29 plantas $\mathrm{m}^{-2}$. O valor máximo ocorreu aos 75 DAE (132 plantas. $\mathrm{m}^{-2}$ ) e por ocasião da colheita esse número foi de 2 plantas. $\mathrm{m}^{-2}$ (Figura 2B). Assim, o valor médio de plantas daninhas, durante o ciclo da cultura, foi de 34 plantas. $\mathrm{m}^{-2}$.

$\mathrm{Na}$ densidade de 15 plantas. $\mathrm{m}^{-1}$ da cultura, o valor inicial das plantas daninhas foi de 38 plantas. $\mathrm{m}^{-2}$ e a maior densidade aos 120 DAE (94 plantas. $\mathrm{m}^{-2}$ ), coincidindo com a colheita (Figura 2C). O valor médio da densidade da comunidade infestante, durante o ciclo da cultura, foi 45 plantas. $\mathrm{m}^{-2}$.

PITELLI (1980) observou que aos 20 DAE, em termos de indivíduos, uma comunidade infestante da cultura do amendoim na época das águas já estava implantada. AGOSTINHO et al. (2006) encontraram as maiores densidades de plantas daninhas aos 30 DAE. Já DIAS et al. (2009) obteve a maior densidade de plantas daninhas aos 45 DAE no espaçamento de 0,80 m e 60 DAE no espaçamento de 0,90 $\mathrm{m}$, porém problemas de precipitação pluviométrica afetaram negativamente a germinação e o desenvolvimento das plantas daninhas. No presente trabalho, não foram constatados problemas de precipitação pluvial (Figura 3A). 


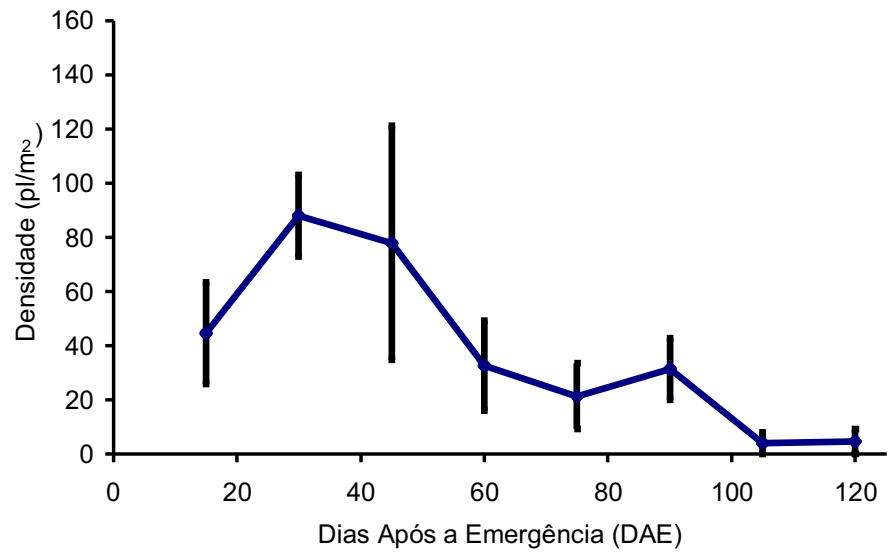

A

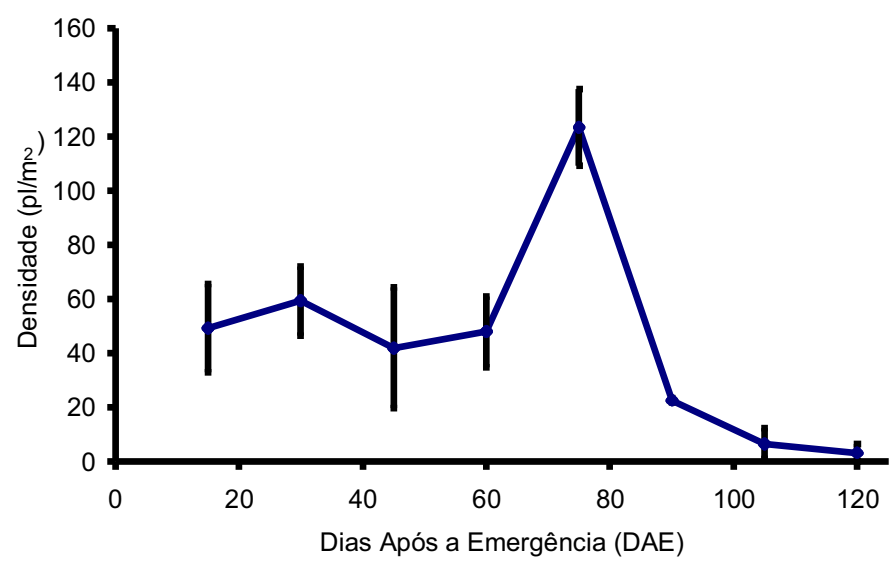

B

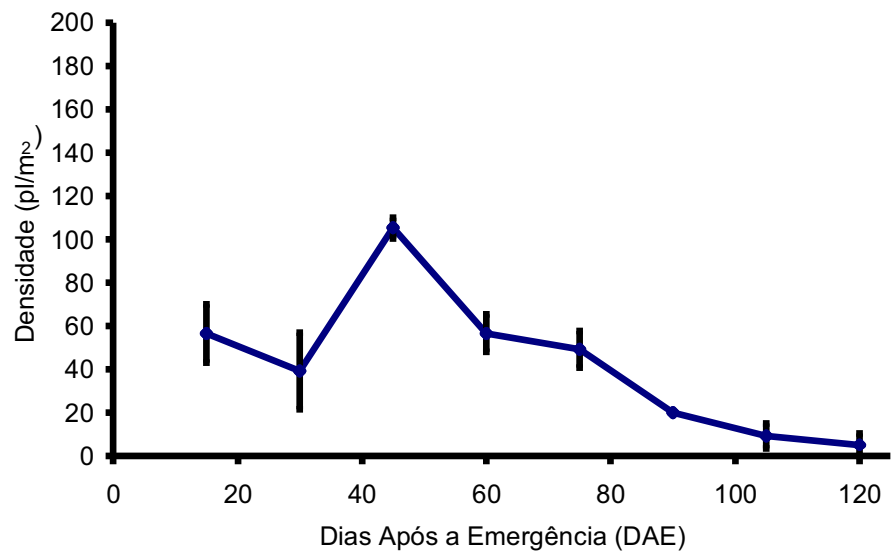

Figura 1. Densidade da comunidade infestante no espaçamento entrelinhas de $0,60 \mathrm{~m}$ nas densidades de semeadura de 5 (A), 10 (B) e 15 (C) plantas. $\mathrm{m}^{-1}$, em função dos períodos de convivência com a cultura do amendoim. Jaboticabal, SP, 2007/2008. 


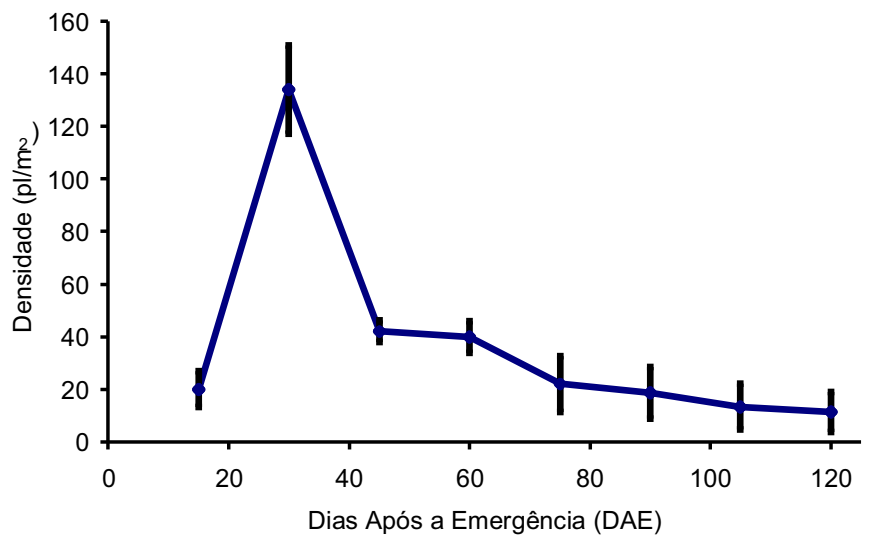

A

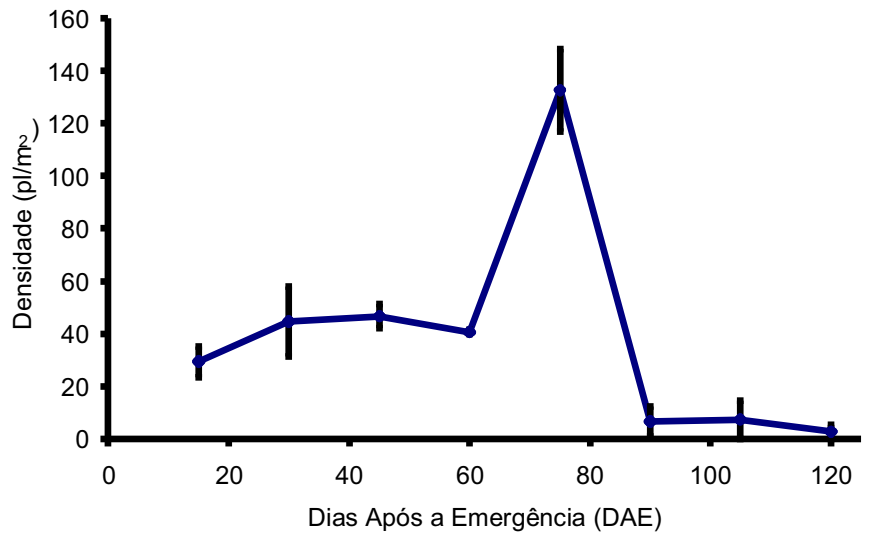

B

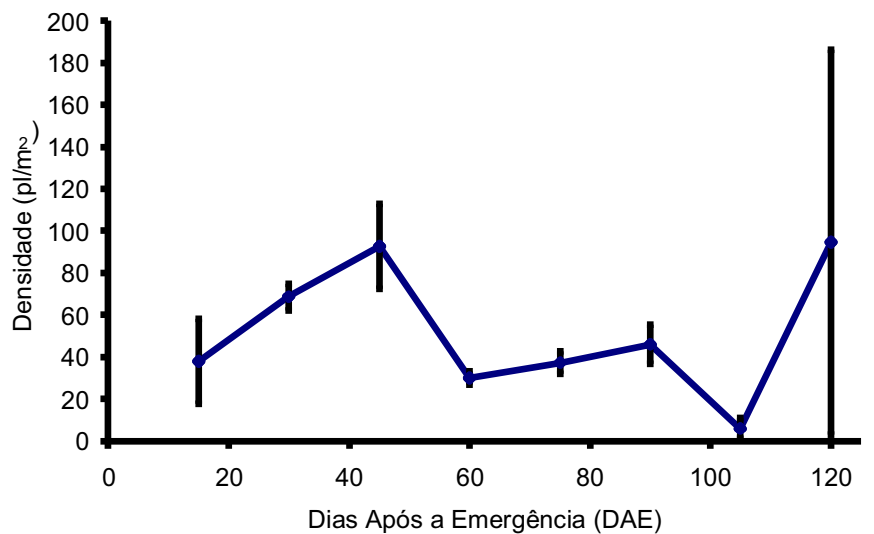

C

Figura 2. Densidade da comunidade das plantas daninhas no espaçamento de $0,90 \mathrm{~m}$ nas densidades de 5 plantas. $\mathrm{m}^{-1}(\mathrm{~A}), 10$ plantas. $\mathrm{m}^{-1}(\mathrm{~B}) \mathrm{e} 15$ plantas. $\mathrm{m}^{-1}(\mathrm{C})$, em função dos períodos de convivência com a cultura do amendoim. Jaboticabal, SP, $2007 / 2008$. 
À medida que aumenta densidade e o desenvolvimento das plantas daninhas, especialmente daquelas que germinam e emergem no início do ciclo de uma cultura, intensifica-se a competição inter e intra-específica, de modo que as plantas daninhas mais altas e mais desenvolvidas tornam-se dominantes, ao passo que as menores são suprimidas ou morrem (RADOSEVICH \& HOLT, 1984). Dekker \& Meggit (1983) verificaram que a taxa de mortalidade de Datura stramonium aumentou à medida que se aumentava a densidade desta espécie, sendo que a densidade decresceu linearmente com o desenvolvimento das plantas.

A massa seca total acumulada pela comunidade infestante, no espaçamento entrelinhas de 0,60 $\mathrm{m}$ na densidade de semeadura de 5 plantas. $\mathrm{m}^{-1}$, no início do ciclo da cultura foi $0,003 \mathrm{~kg} \cdot \mathrm{m}^{-2}$. O maior acúmulo de massa seca foi observado aos $90 \mathrm{DAE}$ $\left(0,920 \mathrm{~kg} \cdot \mathrm{m}^{-2}\right)$ e na colheita, o valor da massa seca total reduziu para $0,560 \mathrm{~kg} \cdot \mathrm{m}^{-2}$ (Figura 3A). O valor médio de massa seca acumulada pela comunidade infestante, no decorrer do ciclo da cultura do amendoim, foi de $0,378 \mathrm{~kg} \cdot \mathrm{m}^{-2}$.

$\mathrm{Na}$ densidade de semeadura de 10 plantas. $\mathrm{m}^{-1}$ a massa seca acumulada pelas plantas daninhas, aos $15 \mathrm{DAE}$, foi $0,013 \mathrm{~kg} \cdot \mathrm{m}^{-2} \mathrm{e}$, na colheita, foi de $0,346 \mathrm{~kg} \cdot \mathrm{m}^{-2}$. O valor máximo ocorreu aos $30 \operatorname{DAE}\left(1,743 \mathrm{~kg} \cdot \mathrm{m}^{-2}\right)$ e o valor médio da massa seca da comunidade infestante foi de $0,610 \mathrm{~kg} \cdot \mathrm{m}^{-2}$ (Figura 3B).

Para a densidade de semeadura de 15 plantas $\mathrm{m}^{-1}$ a massa seca acumulada no início do ciclo da cultura foi de $0,012 \mathrm{~kg} \cdot \mathrm{m}^{-2}$ enquanto na colheita esse acúmulo foi de $0,826 \mathrm{~kg} \cdot \mathrm{m}^{-2}$. O valor máximo para esse parâmetro foi aos $90 \mathrm{DAE}$, com 0,894 $\mathrm{kg} \cdot \mathrm{m}^{-2}$ (Figura 3C). O valor médio do acúmulo de massa seca durante o período de convivência entre a cultura e a comunidade infestante foi $0,349 \mathrm{~kg} \cdot \mathrm{m}^{-2}$.

Para o espaçamento de $0,90 \mathrm{~m}$ entrelinhas e densidade de semeadura de 5 plantas. $\mathrm{m}^{-1}$ a massa seca total da comunidade infestante no início do ciclo da cultura foi de $0,002 \mathrm{~kg} \cdot \mathrm{m}^{-2}$ e na colheita o valor desse parâmetro aumentou, consideravelmente, atingindo o valor de $1,036 \mathrm{~kg} \cdot \mathrm{m}^{-2}$. Porém, a massa seca máxima acumulada na comunidade infestante ocorreu aos $105 \operatorname{DAE}\left(1,113 \mathrm{~kg} \cdot \mathrm{m}^{-2}\right)$. Com isso, a média de acúmulo de massa seca pela comunidade infestante durante o ciclo da cultura foi 0,440 kg. $\mathrm{m}^{-2}$ (Figura 4A). 


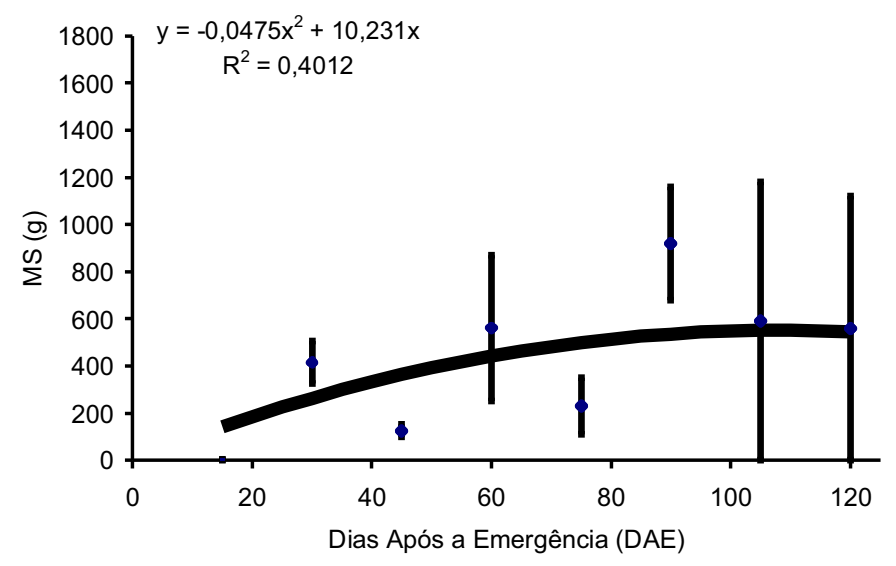

A

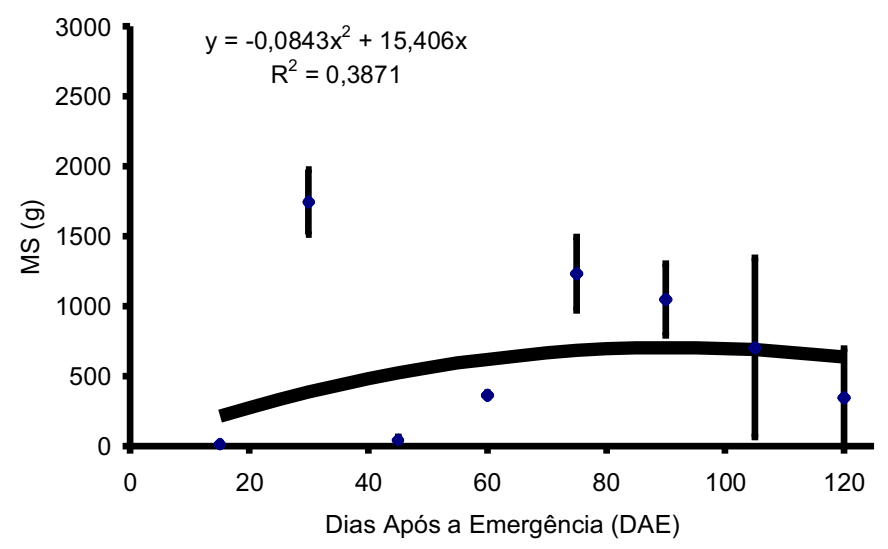

B

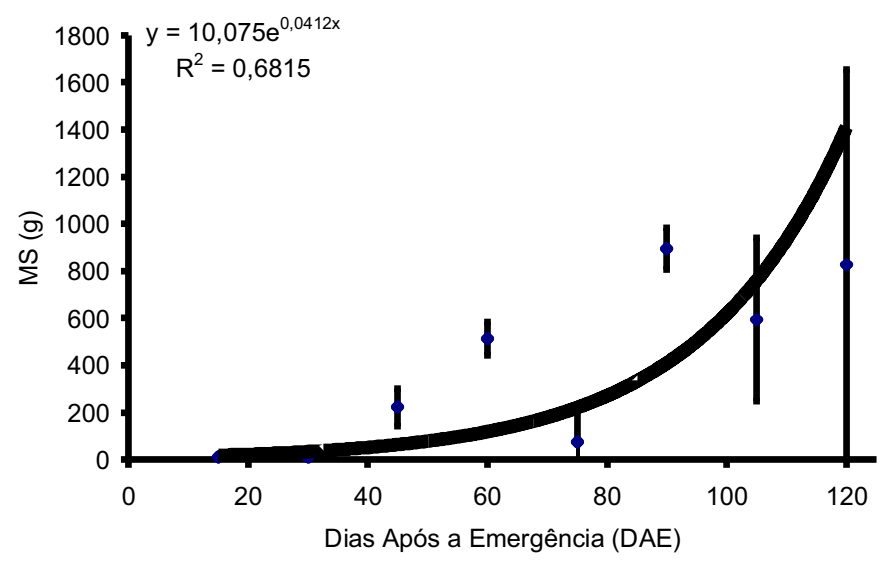

C

Figura 3. Massa seca total das plantas daninhas no espaçamento de $0,60 \mathrm{~m}$ nas densidades de 15 plantas. $\mathrm{m}^{-1}(\mathrm{~A}), 10$ plantas. $\mathrm{m}^{-1}(\mathrm{~B})$ e 15 plantas. $\mathrm{m}^{-1}(\mathrm{C})$, em função dos períodos de convivência com a cultura do amendoim. Jaboticabal, SP, 2007/2008. 
Para a densidade de 10 plantas. $\mathrm{m}^{-1} \mathrm{o}$ acúmulo de massa seca aos 15 DAE foi de $0,006 \mathrm{~kg} \cdot \mathrm{m}^{-2}$ e no final do ciclo da cultura o acúmulo não aumentou significativamente, passando para $0,143 \mathrm{~kg} \cdot \mathrm{m}^{-2}$. Aos 30 DAE ocorreu um acúmulo máximo com 2,217 kg.m-

${ }^{2}$ (Figura 4B); com isso, o valor médio foi $0,587 \mathrm{~kg} \cdot \mathrm{m}^{-2}$.

$\mathrm{Na}$ densidade de 15 plantas $\mathrm{m}^{-1} \mathrm{o}$ valor inicial do acúmulo de massa seca pela comunidade infestante foi de $0,002 \mathrm{~kg} \cdot \mathrm{m}^{-2}$, enquanto na colheita esse valor foi de 0,397 $\mathrm{kg} \cdot \mathrm{m}^{-2}$, sendo que o valor máximo desse parâmetro foi de $1,489 \mathrm{~kg} \cdot \mathrm{m}^{-2}$ aos 90 DAE (Figura 4C). Com isso, o valor médio de acúmulo de massa seca pela comunidade infestante durante o ciclo da cultura foi de $0,481 \mathrm{~kg} \cdot \mathrm{m}^{-2}$.

$\mathrm{Na}$ análise da importância relativa (IR) das espécies de plantas daninhas presentes durante todo o período experimental, independentemente do espaçamento entrelinhas e da densidade de semeadura do amendoim, quatro espécies se destacaram: Digitaria sp.(capim-colchão), Panicum maximum (capim-colonião), Acanthospermum hispidum (carrapicho-de-carneiro) e Cyperus rotundus (tiririca). O comportamento da IR destas espécies no decorrer do período experimental, em função da densidade de semeadura do amendoim, em cada espaçamento, pode ser observado nas Figuras $1 \mathrm{~A}$ e $2 \mathrm{~A}$.

No espaçamento entrelinhas de $0,60 \mathrm{~m}$ na densidade de semeadura de 5 plantas. $\mathrm{m}^{-1}$ (Figura 5), aos $15 \mathrm{DAE}$, a planta daninha de maior importância relativa foi a tiririca(61,70\%), superando, inclusive, a somatória das demais espécies de plantas daninhas, isso deve-se ao fato dessa espécie possuir alta freqüência relativa (FeR.), dominância relativa (DoR) e densidade relativa (DeR). A freqüência relativa é uma medida de relevância da população em termos de ocupação (distribuição) da área de estudo. Já a dominância relativa é uma medida de relevância de população em termos de biomassa seca acumulada ou do recrutamento de recursos do meio. A densidade relativa das populações é uma medida da relevância da população em termos de números de indivíduos (MUELLER-DOMBOIS \& ELLEMBERG, 1974). Contudo, sua importância relativa decresceu, após os $30 \mathrm{DAE}(4,79 \%)$, voltando a aumentar aos 45 
DAE $(26,21 \%)$, quando apresentou a maior DeR e DoR. Após esse período foi pequena a contribuição da tiririca no parâmetro importância relativa.

A presença de capim-colchão foi constatada aos $30 \mathrm{DAE}$ e, pela própria biologia da espécie, continuou seu desenvolvimento até os $75 \mathrm{DAE}$, quando se tornou a espécie mais importante $(24,62 \%)$ dentre as quatro analisadas, pois nesse período apresentou a maior FeR. Contudo, aos 90 DAE reduziu sua importância na comunidade e a partir desta época não apareceu mais dentre as mais importantes.

A importância relativa do capim-colonião presente aos 30 DAE (26,81\%) correspondeu a rebrota de touceiras provenientes de anos anteriores e, mesmo com a capina manual de muitas destas, algumas reinfestaram a área. Aos 60 DAE, verificouse o surgimento de plântulas dessa espécie, que se desenvolveram e apareceram praticamente em todas as avaliações realizadas até a colheita, destacando-se como a espécie mais importante a partir dos 105 DAE com IR de 53,58\% e 39,68\% aos 120 DAE. Em ambas situações essa espécie obtinha os maiores índices de FeR e DoR.

A importância relativa do carrapicho-de-carneiro foi observada, inicialmente, aos $30 \mathrm{DAE}$, com convivência na cultura até os $90 \mathrm{DAE}$, quando se tornou a espécie mais importante $(21,64 \%)$ dentre as analisadas, sendo que obteve o maior índice de FeR. Aos 105 DAE não foi constatada sua ocorrência, mas aos 120 DAE apareceu como a segunda espécie de maior importância relativa, sendo superada, somente, pelo capimcolonião.

No espaçamento entrelinhas de $0,60 \mathrm{~m}$ e densidade de semeadura de 10 plantas. $\mathrm{m}^{-1}$ (Figura 6) a tiririca foi a espécie mais importante $(86,99 \%)$ no início de desenvolvimento da cultura (15DAE) quando obteve os maiores índices de Der, FeR e DoR, mas, aos $30 \mathrm{DAE}$, perdeu importância para as demais plantas. Aos $45 \mathrm{DAE}$ esta espécie voltou a ser a mais importante com IR de 20,66\% e com o maior índice de FeR. A partir desse período sua importância relativa decresceu tendendo a zero aos 90 DAE. 


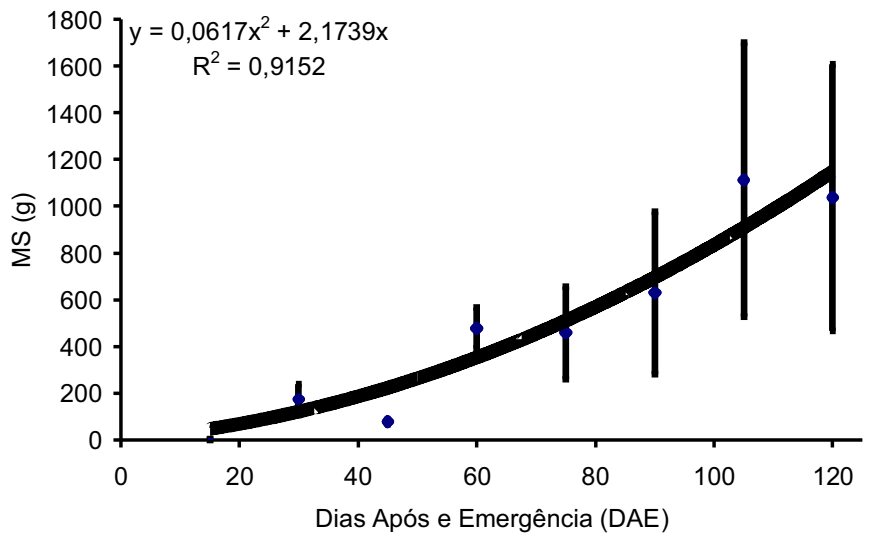

A

B

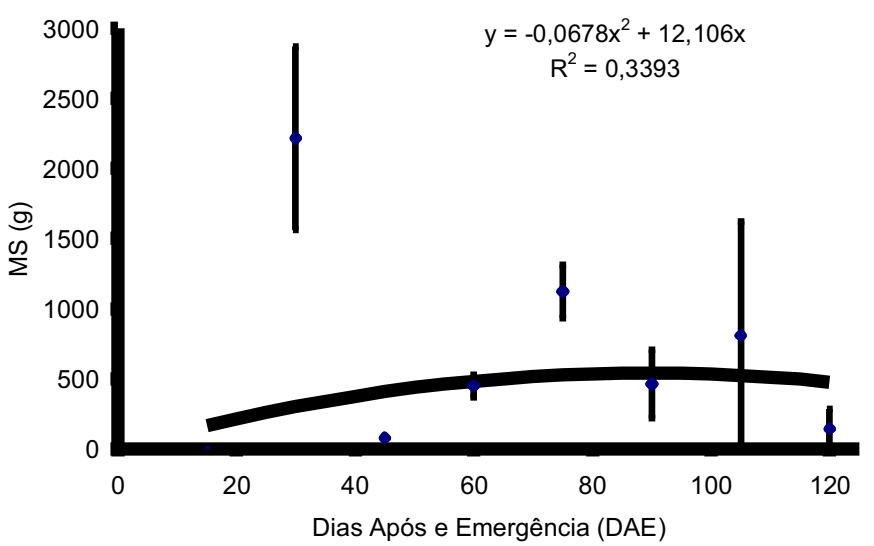

C

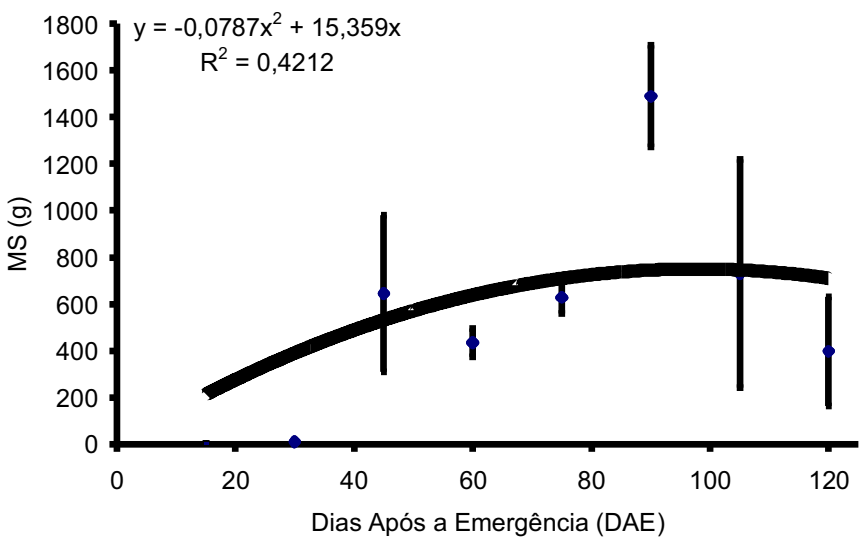

Figura 4. Massa seca total das plantas daninhas no espaçamento de $0,90 \mathrm{~m}$ nas densidades de 5 plantas. $\mathrm{m}^{-1}(\mathrm{~A}), 10$ plantas. $\mathrm{m}^{-1}(\mathrm{~B})$ e 15 plantas. $\mathrm{m}^{-1}(\mathrm{C})$, em função dos períodos de convivência com a cultura do amendoim. Jaboticabal, SP, 2007/2008. 


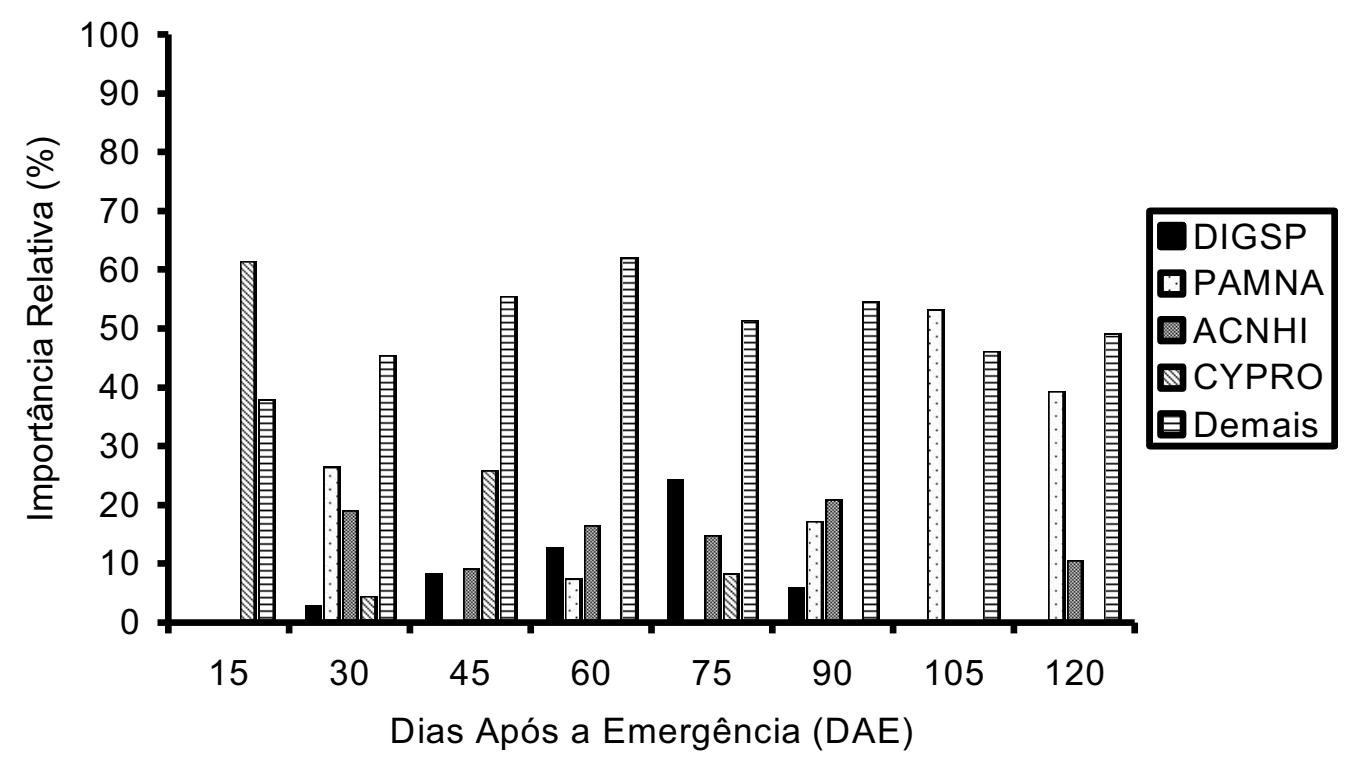

Figura 5. Importância relativa do capim-colchão (DIGSP), capim-colonião (PANMA), carrapicho-de-carneiro (ACNHI), tiririca (CYPRO) e demais plantas daninhas infestando a cultura do amendoim no espaçamento de 0,60 m entrelinhas e densidade de semeadura de 5 plantas. $\mathrm{m}^{-1}$.

O capim-colchão começou a ser observado na área aos 45 DAE e sua presença na comunidade infestante ocorreu até os $120 \mathrm{DAE}$, sendo a espécie mais importante aos 60 DAE $(21,76 \%)$ e 90 DAE (27\%). No primeiro período esse espécie apresentava o maior índice de DoR, e no segundo período o maior índice perante as demais espécies era a DeR, enquanto que nos dois períodos a FeR foi a maior.

Aos 30 DAE as rebrotas de touceiras de capim-colonião fizeram que esta espécie fosse a mais importante (42,69\%). Porém, esta espécie desapareceu da área aos 45 DAE e voltou a aparecer aos 60 DAE. Entretanto, até a colheita, o capim-colonião não se destacou dentre as espécies mais importantes. A inexistência de capim-colonião aos 45 DAE deve-se provavelmente a erro amostral, uma vez que a infestação desta espécie se caracterizou por brotação de touceiras que estavam aleatoriamente dispersas na área. 
O carrapicho-de-carneiro foi observado, na área, aos 30 DAE. Foi a espécie de maior importância relativa, 25,59\%, aos $75 \mathrm{DAE}$, quando obteve os maiores índices de DeR e FeR, aos 105 DAE (21,50\%) devido a sua alta DoR e 120 DAE (24,23\%), o que demonstrou sua grande capacidade competitiva com as demais plantas daninhas presentes (Figura 6).

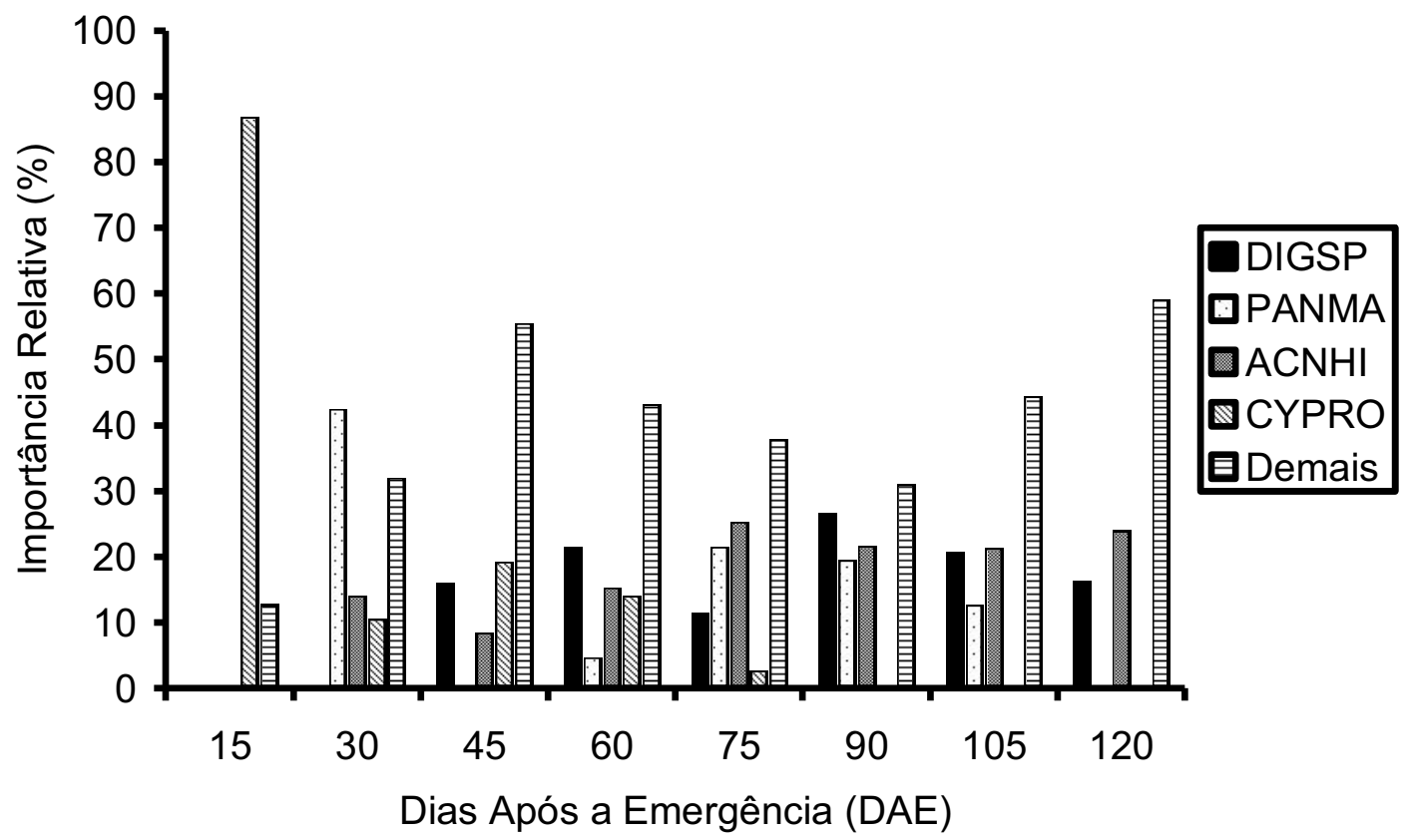

Figura 6. Importância relativa do capim-colchão (DIGSP), capim-colonião (PANMA), carrapicho-de-carneiro (ACNHI), tiririca (CYPRO) e demais plantas daninhas infestando a cultura do amendoim no espaçamento de 0,60 m entrelinhas e densidade de semeadura de 10 plantas. $\mathrm{m}^{-1}$.

Para a densidade de semeadura de 15 plantas. $\mathrm{m}^{-1}$ no espaçamento entrelinhas de 0,6 m (Figura 7), a tiririca foi a espécie mais importante aos $15(90,39 \%)$ e 30 DAE $(54,32 \%)$, superando a soma da Importância relativa de todas as outras espécies presentes na área, sendo que nos dois períodos citados essa espécie obtinha os maiores valores em todos índices, DeR, FeR e Dor. Após esse período, sua importância decresceu bruscamente sendo que aos 60 DAE esta espécie não era mais observada na área. 
O capim-colchão apareceu na área aos 45 DAE e foi encontrado até os 120 DAE. Foi a espécie mais importante nos períodos de $60 \mathrm{DAE}(22,13 \%), 75 \operatorname{DAE}(21,98 \%)$, devido a sua alta freqüência relativa, 90 DAE (44,57\%), quando obtinha os maiores valores para todos os índices e 105 DAE (34,32\%), pela alta FeR e DoR. Aos 90 DAE a soma de sua importância relativa $(44,57 \%)$ ultrapassou todas as outras 3 plantas daninhas destacadas.

A presença do capim-colonião ocorreu dos 45 DAE aos 90 DAE, destacando-se com a espécie de maior importância relativa (35,62\%) aos 120 DAE, com altos valores em todos os índices, DeR, FeR e DoR.

O carrapicho-de-carneiro foi observado, praticamente, em todo o ciclo da cultura, dos 30 DAE aos 120 DAE. Entretanto, sua importância relativa foi maior (19\%) aos 45 DAE devido a sua alta DeR e FeR.

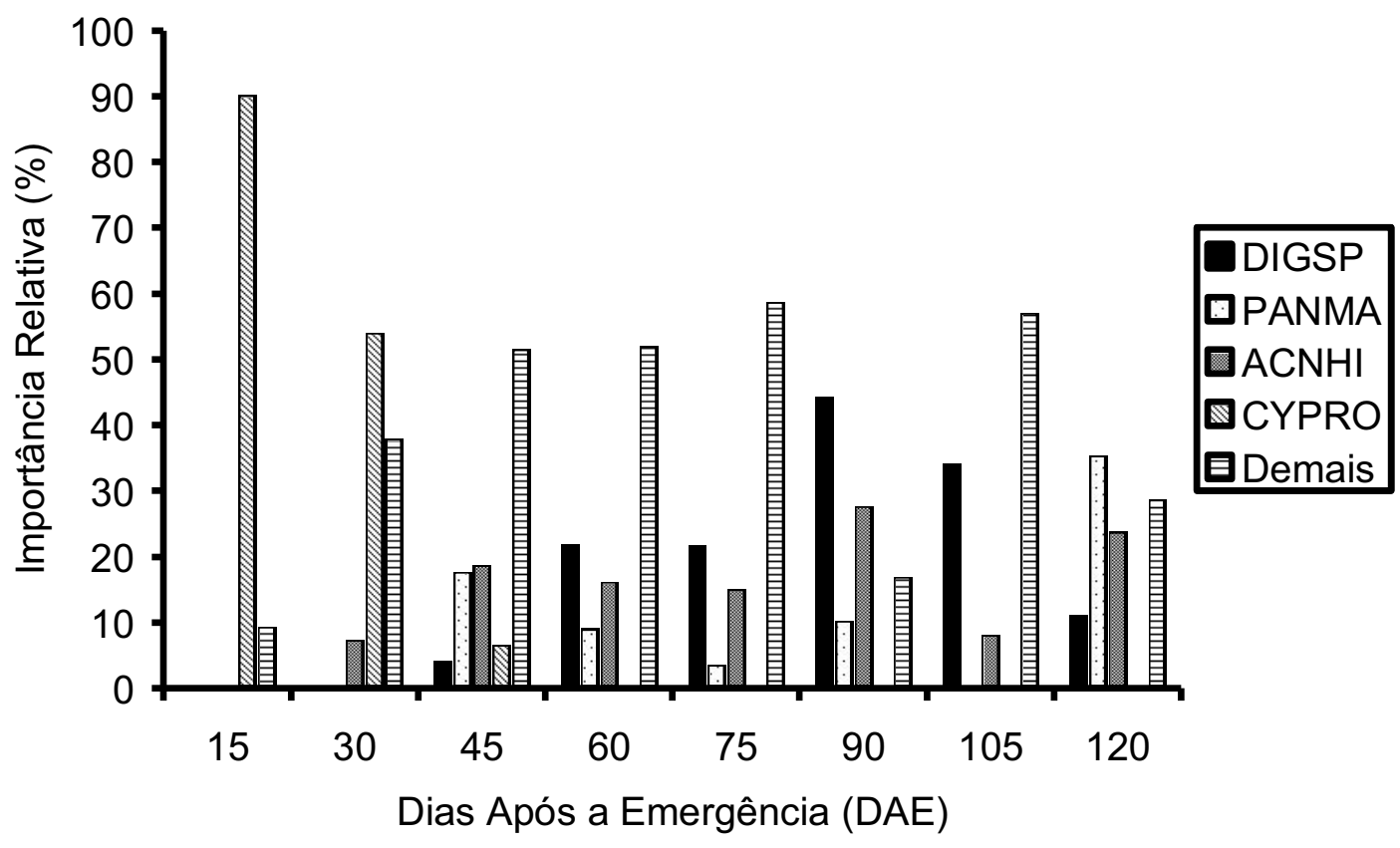

Figura 7. Importância relativa do capim-colchão (DIGSP), capim-colonião (PANMA), carrapicho-de-carneiro (ACNHI), tiririca (CYPRO) e demais plantas daninhas infestando a cultura do amendoim no espaçamento de 0,60 m entrelinhas e densidade de semeadura de 15 plantas. $\mathrm{m}^{-1}$. 
No espaçamento entrelinhas de 0,9 m na densidade de semeadura do amendoim de 5 plantas. $\mathrm{m}^{-1}$ (Figura 8), a tiririca foi a espécie com maior importância relativa $(51,20 \%)$ aos $15 \mathrm{DAE}$, em que sua importância superou a somatória de todas as outras plantas e conseqüentemente obteve os maiores valores para todos os índices, já aos 30 DAE ela perdeu, significativamente, a importância e após esse período não foi mais observada.

O capim-colchão apareceu, praticamente, em todo o ciclo da cultura. Foi observado, inicialmente, aos 30 DAE e conviveu com o amendoim até os 120 DAE com importância relativa maior $(15,83 \%)$ aos $45 \mathrm{DAE}, 60 \mathrm{DAE}(35,82 \%)$, quando todos os índices obtiveram os maiores valores e 75 DAE $(17,69 \%)$ e 90 DAE $(25,94 \%)$ esse fato ocorreu devido a alta DeR.

Novamente, em decorrência da brotação das touceiras remanescentes, o capimcolonião foi à espécie mais importante (20,58\%) aos 30 DAE. Aos 45, 60 e 75 DAE não mais se constatou sua presença na área. Foi novamente observada sua presença aos 90, 105 e 120 DAE, mas com importância relativa menor (Figura 8).

Assim como o capim-colchão, o carrapicho-de-carneiro foi observado na área por, praticamente, todo o ciclo da cultura (Figura 8). Contudo, ao contrário do capimcolchão, essa espécie foi a mais importante $(26,65 \%)$ aos 105 DAE, devido a alta FeR e aos 120 DAE $(32,09 \%)$ além da alta FeR, possuia alta DeR.

Aos 15 DAE no espaçamento entrelinhas de 0,9 m na densidade de semeadura de 10 plantas. $\mathrm{m}^{-1}$ (Figura 9) a tiririca foi a espécie de maior importância relativa $(88,76 \%)$, sendo maior que a somatória das importâncias relativas das demais espécies, com os mais altos índices de DeR, FeR e DoR, porém não foi encontrada aos 30 DAE. Aos 45 DAE reaparece na área, como a mais importante $(11,15 \%)$ devido ao alto índice de DeR, não sendo mais constatada nas demais épocas de avaliação.

Ao se analisar a ocorrência do capim-colchão, observou-se que ele apareceu aos 30 DAE e permaneceu na comunidade infestante até a colheita. Essa foi a espécie de maior importância relativa $(34,78 \%)$ aos 60 DAE, decrescendo acentuadamente aos 75 
DAE. Após esse período, o capim-colchão foi aumentando a importância na comunidade infestante tornando-se, aos 120 DAE, a espécie mais importante (46,38\%). Nos dois períodos essa espécie possuía os mais altos índices de DeR, FeR e DoR.

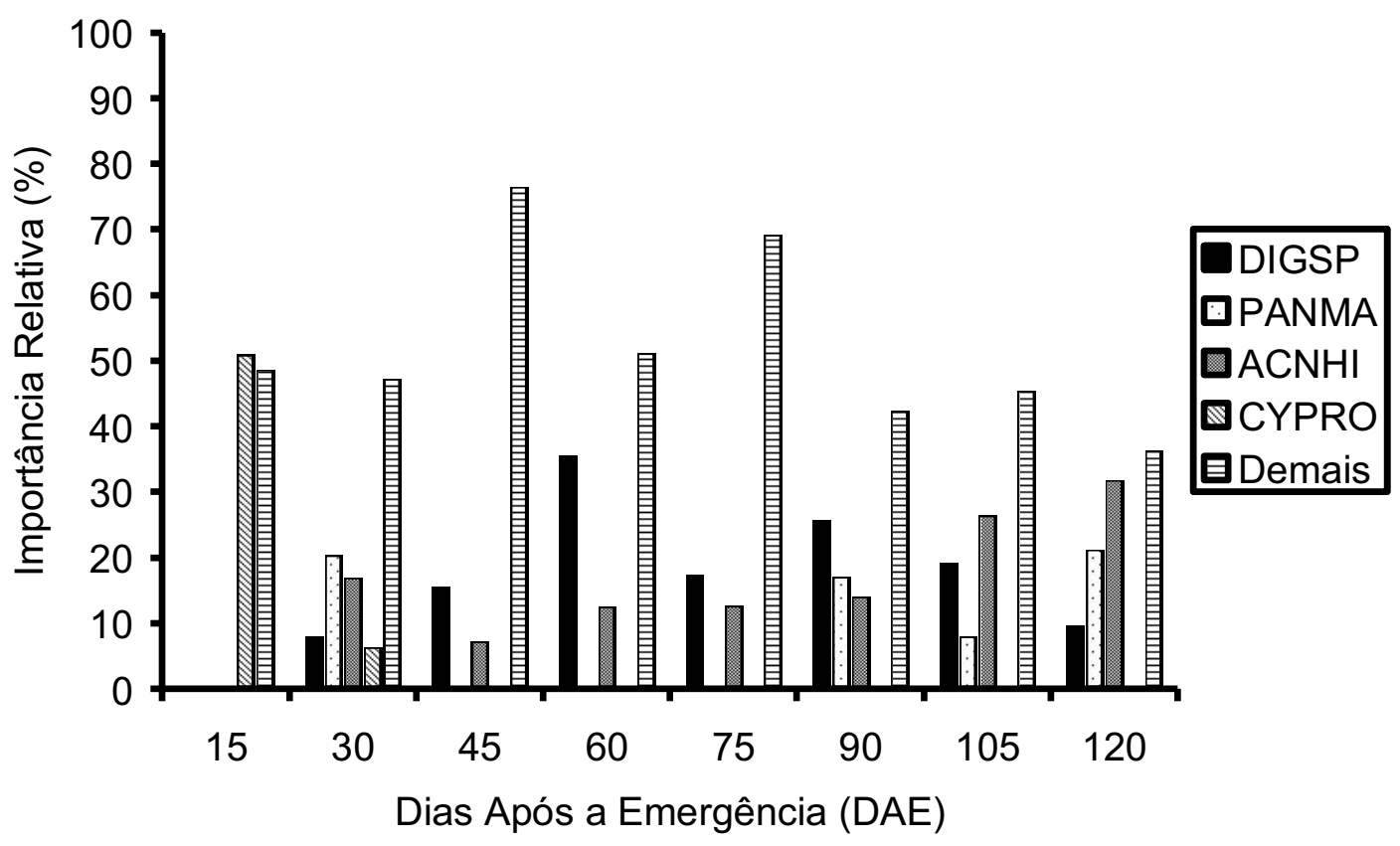

Figura 8. Importância relativa do capim-colchão (DIGSP), capim-colonião (PANMA), carrapicho-de-carneiro (ACNHI), tiririca (CYPRO) e demais plantas daninhas infestando a cultura do amendoim no espaçamento de 0,90 m entrelinhas e densidade de semeadura de 5 plantas. $\mathrm{m}^{-1}$.

A presença do capim-colonião foi observada em três períodos ao longo do ciclo da cultura; aos 30 DAE com importância relativa de 45,34\%, conforme mencionado anteriormente, em decorrência da brotação de touceiras existentes na área; aos 75 DAE, quando foi a espécie de maior importância relativa $(17,96 \%)$, isso devido a sua alta FeR e DoR e aos 90 DAE por não estar presente e reapareceu aos 105 DAE. Não foi constada sua presença aos 120 DAE.

O carrapicho-de-carneiro foi observado na área entre 30 e 105 DAE e durante esses períodos foi, praticamente, estável seu índice de importância relativa, exceto aos 
$105 \mathrm{DAE}$, quando a espécie foi a mais importante $(28,40 \%)$ e com os mais altos índices de DeR, FeR e DoR.

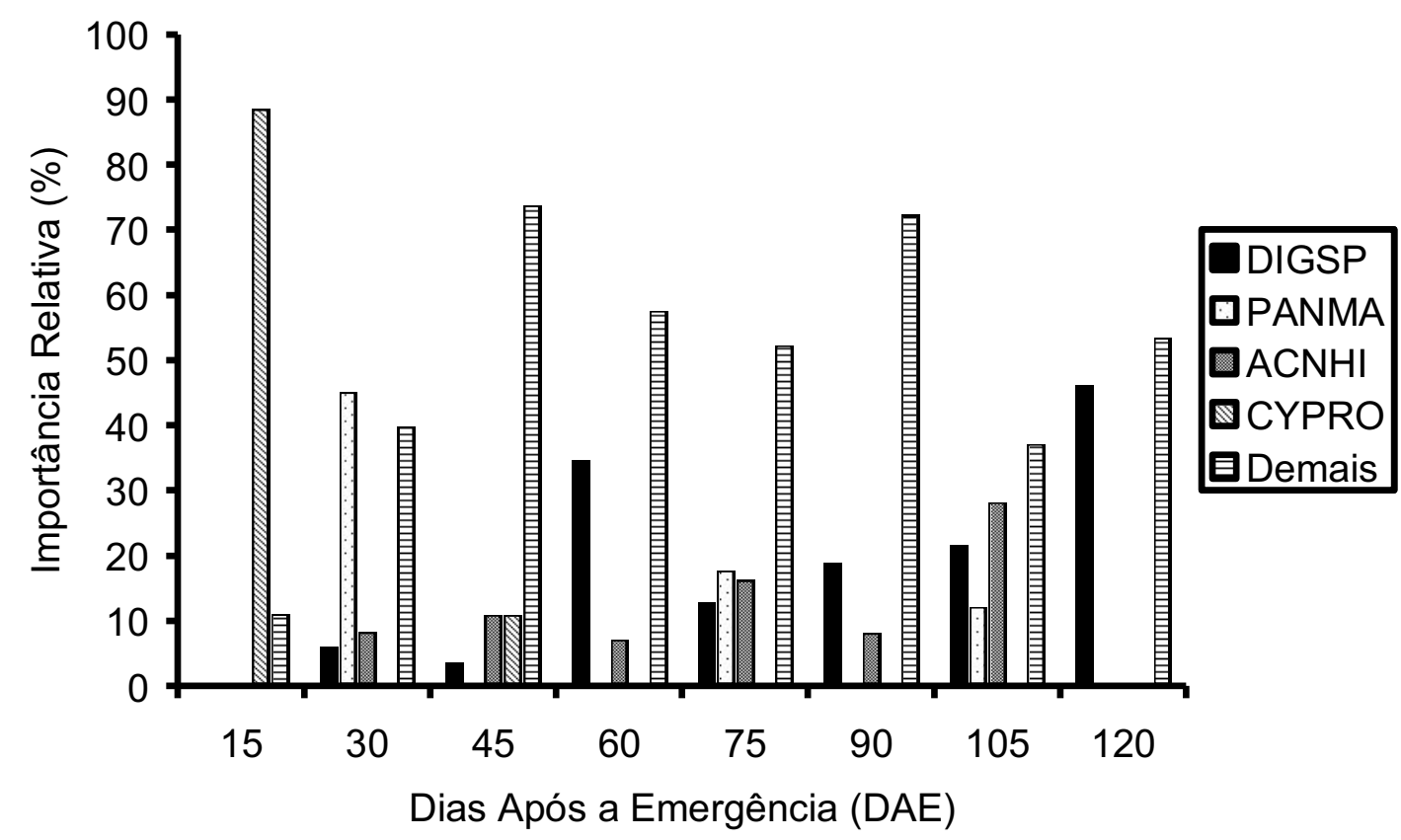

Figura 9. Importância relativa do capim-colchão (DIGSP), capim-colonião (PANMA), carrapicho-de-carneiro (ACNHI), tiririca (CYPRO) e demais plantas daninhas infestando a cultura do amendoim no espaçamento de 0,90 m entrelinhas e densidade de semeadura de 10 plantas. $\mathrm{m}^{-1}$.

Na densidade de semeadura de 15 plantas. $\mathrm{m}^{-1}$ e espaçamento entrelinhas de 0,9 m (Tabela 10) a tiririca foi a espécie de maior importância relativa (55,79\%) aos 15 DAE, sendo maior que a somatória das importâncias relativas das demais espécies e com os mais altos índices de DeR, porém, com queda acentuada aos 30 DAE e desaparecendo da área após esse período.

O capim-colchão dos 15 aos 105 DAE apresentou um crescimento exponencial no seu índice de importância relativa, sendo que aos 90 (32,01\%) e 105 DAE (39,93\%) foi à espécie mais importante na área. Aos 105 DAE o valor de importância foi maior que a 
somatória das demais plantas daninhas e em ambos os períodos foi observado os mais altos valores para todos os índices.

O capim-colonião apresentou aumento no valor do índice de importância relativa $(39,08 \%)$ aos 45 DAE devido a brotação de touceiras já existentes, anteriormente na área. Aos 60 DAE uma nova brotação de capim-colonião foi observada, contribuindo para que dobrasse o índice de importância relativa aos 75 DAE e novamente aos 90 DAE. A partir desse período não foi mais observada a presença de capim-colonião.

O carrapicho-de-carneiro foi observado na área dos 30 aos 120 DAE; aos 30 DAE foi a espécie mais importante $(6,73 \%)$ dentre as destacadas, mas com um índice de importância relativa menor quando comparado ao da somatória das demais plantas daninhas; aos 45 DAE o carrapicho-de-carneiro foi a segunda espécie mais importante da área, sendo superada pelo capim-colonião; aos 60, 90 e 105 DAE foi a segunda espécie mais importante, superada pelo capim-colchão e aos $120 \mathrm{DAE}$, na colheita do amendoim, foi a planta daninha com maior índice de importância relativa $(20,53 \%)$ e esse fato deve-se a sua alta FeR.

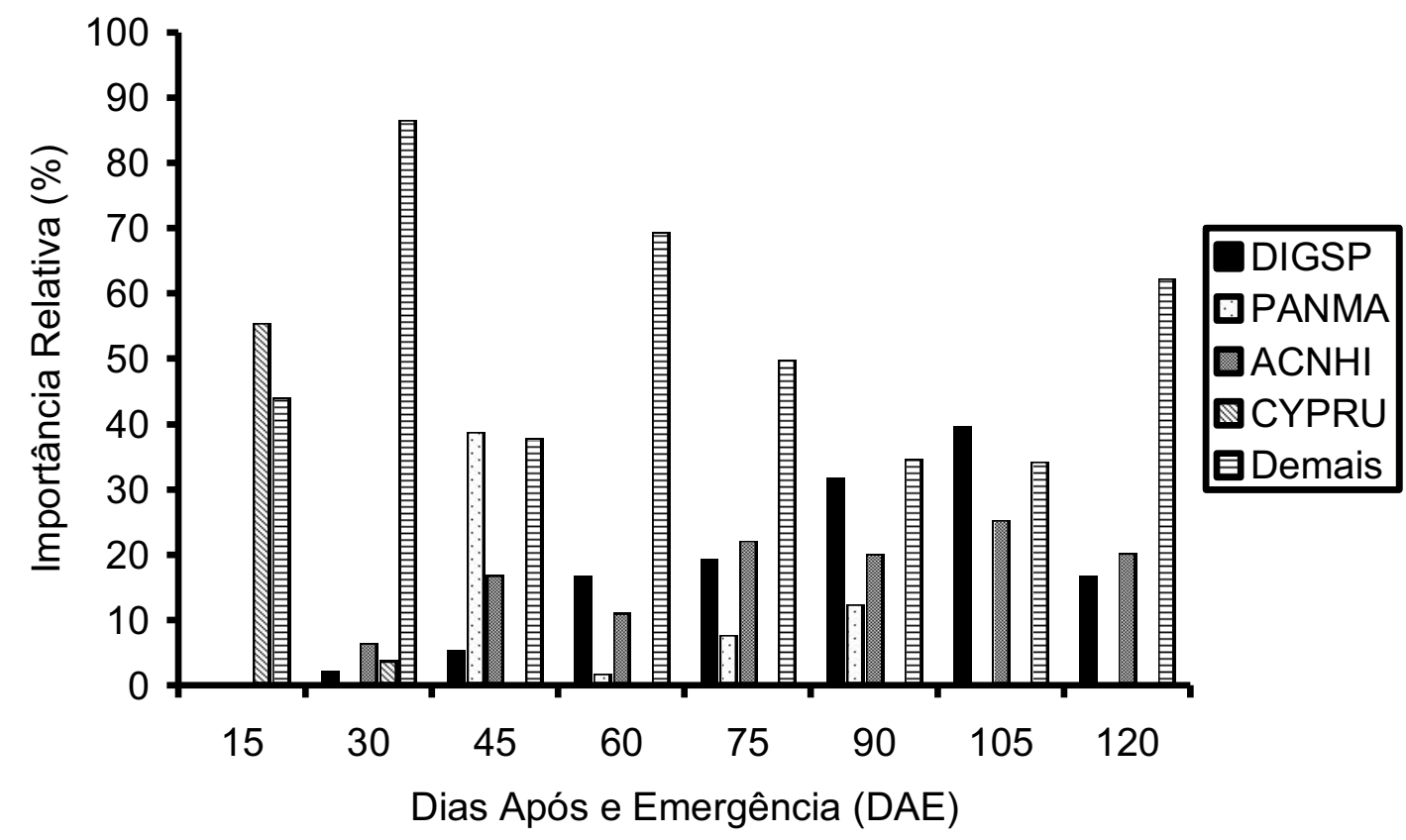

Figura 10. Importância relativa do capim-colchão (DIGSP), capim-colonião (PANMA), carrapicho-de-carneiro (ACNHI), tiririca (CYPRO) e demais plantas 
daninhas infestando a cultura do amendoim no espaçamento de $0,90 \mathrm{~m}$ entrelinhas e densidade de semeadura de 15 plantas. $\mathrm{m}^{-1}$.

Com os apresentados pode-se verificar que independentemente do espaçamento entre as linhas e da densidade de semeadura da cultura do amendoim a tiririca foi a espécie de planta daninha mais importante durante o período inicial de desenvolvimento da cultura e em alguns casos chegou a ser a mais importante até os 45 DAE. Porém, a tiririca não tolera sombreamento e em virtude disso, com o fechamento da cultura, não mais se constatou suas manifestações epígeas.

A partir desse momento, outras espécies de plantas daninhas começaram a ter mais importância, podendo esse comportamento ser até mesmo explicado pela biologia de cada espécie. Isolando-se as ocorrências das rebrotas de capim-colonião aos 30 DAE em praticamente todas as sub-parcelas. Já quando trata-se de plantas novas sua presença é verifica mais vezes nos tratamentos com espaçamento de 0,60 m. Esse fato pode ser explicado por essa espécie, embora muito agressiva, não tem boa competitividade com outras espécies agressivas também, como nesse caso o capimcolchão e o carrapicho-de-carneiro.

No espaçamento de $0,90 \mathrm{~m}$ o capim colchão foi mais observada e sempre após sua presença a produtividade da cultura diminuía consideravelmente. O fato dessa espécie ser mais observada nesse espaçamento pode ser explicado pelo fato do seu crescimento ser prostrado, quando mais espaço entre as linhas da cultura pra ela se desenvolver, mais isso acontecerá.

A presença do carrapicho-de-carneiro foi observada, na maioria das vezes, depois das outras espécies de plantas daninhas, e coincidentemente sempre nos períodos a partir dos quais não mais se observava produção da cultura. Esta observação também foi feita por DIAS et al. (2009). 


\subsection{Produtividade da cultura}

As maiores produções, independente do espaçamento entrelinhas e da densidade de semeadura, o valor máximo observado para a produção ocorreu quando a cultura não conviveu com as plantas daninhas em nenhum momento. Este resultado corrobora com os obtidos por AGOSTINHO et al. (2006); DIAS et al. (2009); NEPOMUCENO et al. (2005); NEPOMUCENO et al. (2006).

A produção final, em reposta a cada período de convivência da cultura do amendoim pode ser visualizada na Tabela 4.

Tabela 4. Produção final de amendoim em vagens $\left(\mathrm{kg} \cdot \mathrm{ha}^{-1}\right)$, em função da densidade de plantas e períodos de convivência. Jaboticabal, SP, 2007/2008.

\begin{tabular}{|c|c|c|c|c|c|c|}
\hline \multirow{4}{*}{$\begin{array}{c}\text { Período } \\
\text { (dias) }\end{array}$} & \multicolumn{3}{|c|}{$0,60 \mathrm{~m}$} & \multicolumn{3}{|c|}{$0,90 \mathrm{~m}$} \\
\hline & \multicolumn{6}{|c|}{ Densidade de plantas } \\
\hline & $83.333^{12}$ & $166.666^{/ 2}$ & $250.000^{12}$ & $55.555^{12}$ & $111.111^{/ 2}$ & $166.666^{12}$ \\
\hline & $(5)^{/ 1}$ & $(10)^{/ 1}$ & $(15)^{/ 1}$ & $(5)^{/ 1}$ & $(10)^{/ 1}$ & $(15)^{/ 1}$ \\
\hline 0 & 5.500 & 6.250 & 6.417 & 5.111 & 5.566 & 6.056 \\
\hline 15 & 5.109 & 5.565 & 4.860 & 4.000 & 4.430 & 3.856 \\
\hline 30 & 4.760 & 5.820 & 5.593 & 3.503 & 4.414 & 3.466 \\
\hline 45 & 4.149 & 5.208 & 4.756 & 3.166 & 3.378 & 2.269 \\
\hline 60 & 4.202 & 4.248 & 3.892 & 1.761 & 3.344 & 0 \\
\hline 75 & 4.123 & 2.777 & 3.759 & 0 & 2.338 & 0 \\
\hline 90 & 3.722 & 0 & 1.663 & 0 & 0 & 0 \\
\hline 105 & 0 & 0 & 1.420 & 0 & 0 & 0 \\
\hline 120 & 0 & 0 & 0 & 0 & 0 & 0 \\
\hline
\end{tabular}

No espaçamento de $0,60 \mathrm{~m}$ e densidade de semeadura de 5 plantas. $\mathrm{m}^{-1} \mathrm{a}$ produtividade máxima foi de $5.500 \mathrm{~kg} \cdot \mathrm{ha}^{-1}$ e a partir dos 105 DAE não mais se obteve produção devido a infestação das plantas daninhas. Admitindo-se uma perda de $5 \%$ na 
produtividade, valor esse usado em todas as densidades de semeadura da cultura e nos dois espaçamentos, foi determinado que o Período Anterior a Interferência (PAI) foi de 86 DAE; para a densidade de semeadura de 10 plantas. $\mathrm{m}^{-1} \mathrm{o}$ valor máximo de produção foi de $6.250 \mathrm{~kg} \cdot \mathrm{ha}^{-1}$ e não obteve-se mais produção a partir dos 90 DAE. O PAl calculado foi de $36 \mathrm{DAE}$; na densidade de semeadura de 15 plantas. $\mathrm{m}^{-1}$ a máxima produção foi de $6.417 \mathrm{~kg} \cdot \mathrm{ha}^{-1} \mathrm{e}$, assim como nas outras densidades de semeadura, foi decrescendo até que no final da ciclo da cultura, aos 120 DAE já não mais foi observada produção da cultura. O PAI para essa densidade e esse espaçamento foi de 13 DAE (Figura 11).

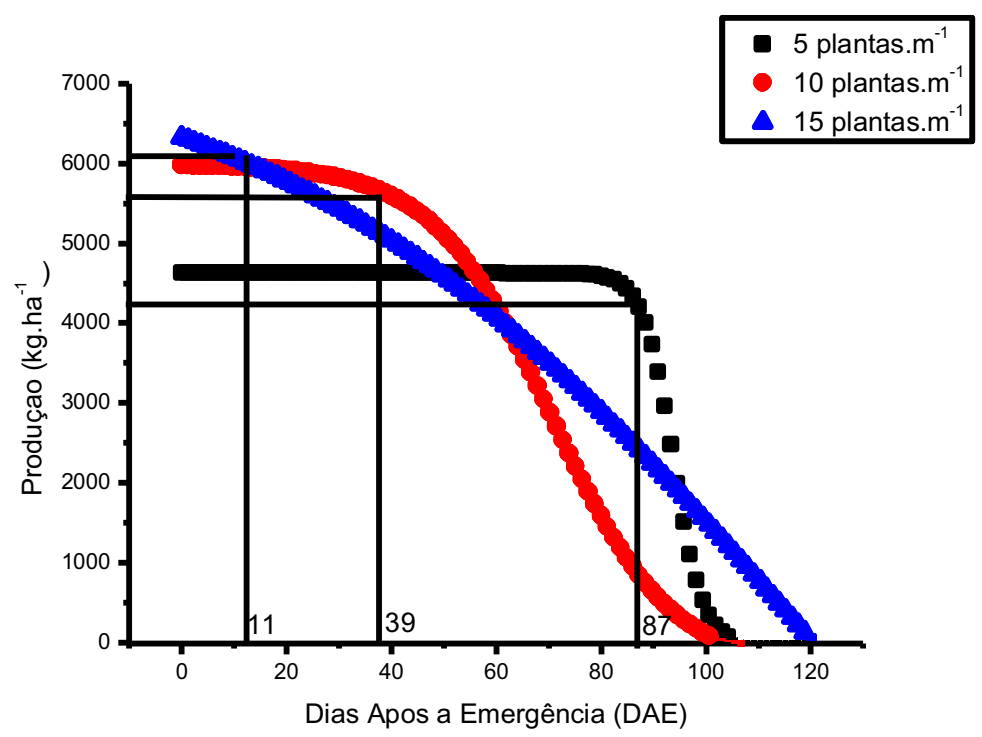

Figura 11. Produtividade de amendoim em casca, no espaçamento de $0,60 \mathrm{~m}$ e densidade de semeadura de 5, 10 e 15 plantas. $\mathrm{m}^{-1}$, em função dos períodos de convivência. Jaboticabal, SP, 2007/2008.

No espaçamento entrelinhas de $0,90 \mathrm{~m}$ e densidade de semeadura de 5 plantas. $\mathrm{m}^{-1}$ a produção máxima obtida de $5.111 \mathrm{~kg} \cdot$ ha $^{-1}$ e a partir dos 75 DAE não mais foi possível realizar a colheita devido a alta infestação de plantas daninhas. O PAI calculado foi de $14 \mathrm{DAE}$; Para a densidade de semeadura de 10 plantas. ${ }^{-1}$ o PAI 
calculado foi de 20 DAE. A partir dos 90 DAE não foi mais obtida a produção das parcelas que conviveram com as plantas daninhas, enquanto as parcelas que não conviveram tiveram uma produção de $5.566 \mathrm{~kg} \cdot \mathrm{ha}^{-1}$; a produção na parcela que não conviveu com plantas daninhas na densidade de semeadura de 15 plantas. $\mathrm{m}^{-1}$ foi de $4.861 \mathrm{~kg} \cdot \mathrm{ha}^{-1}$ e o PAl calculado foi de 21 DAE e a partir dos 60 DAE não mais foi obtida produção (Figura 12).

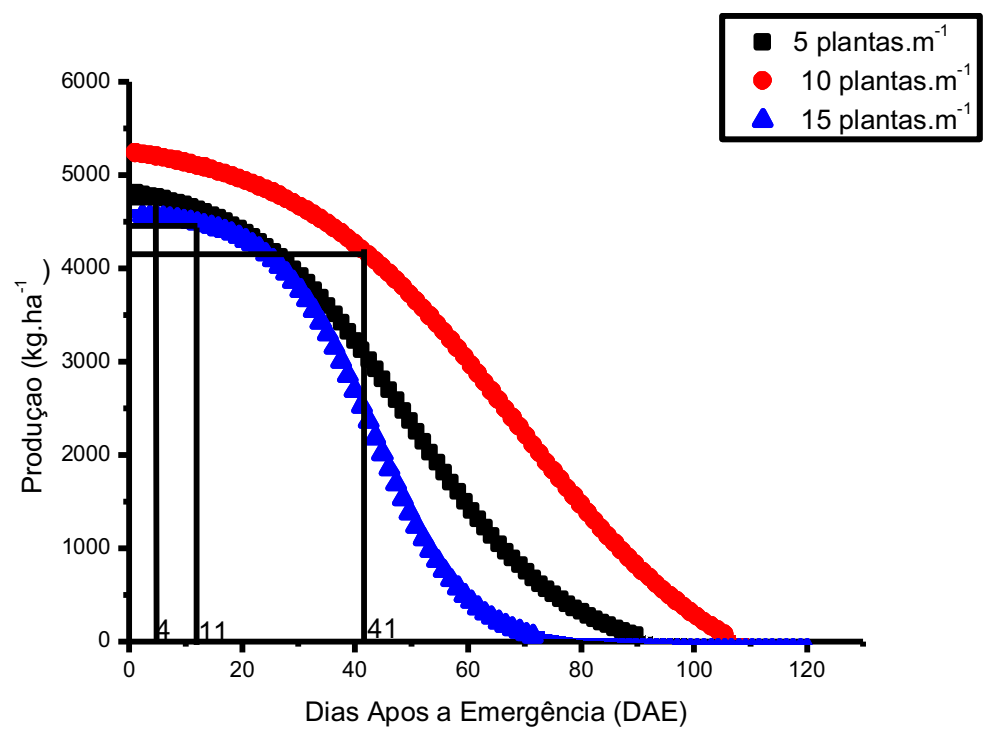

Figura 12. Produtividade de amendoim em casca, no espaçamento de $0,90 \mathrm{~m}$ e densidade de semeadura de 5, 10 e 15 plantas. $\mathrm{m}^{-1}$, em função dos períodos de convivência. Jaboticabal, SP, 2007/2008.

Segundo BIANCO (1978) e PITELLI (1980) a interferência das plantas daninhas altera em maior proporção a produtividade por indivíduo do que a sobrevivência das plantas de amendoim.

Quando comparado com outros trabalhos, percebe-se que as perdas obtidas foram muito altas, já que em outras ocasiões elas não ultrapassaram 63\%, mesmo em condições da baixa disponibilidade hídrica (BIANCO, 1978; PACHECO, 1980; PITELLI et al., 1981; PITELLI et al., 1984; GAVIOLI, 1985; MARTINS \& PITELLI, 1994; KASAI et 
al., 1997, PITELLI et al., 2002). Porém, deve-se também ressaltar que nestes trabalhos as cultivares utilizadas foram de porte ereto. Quando se compara com trabalhos nos quais foram utilizados cultivares de porte rasteiro, as perdas de produtividade variaram de 80 a 90\% (AGOSTINHO et al., 2006; DIAS et al., 2009; NEPOMUCENO et al.; 2005, NEPOMUCENO et al., 2006), assemelhando-se as obtidas no presente trabalho. Isso pode indicar maior susceptibilidade dessas cultivares às plantas daninhas. FEAKIM (1973) concluiu que os cultivares de porte ereto são mais tolerante à interferência com as plantas daninhas que as cultivares de crescimento prostrado, talvez pela formação de uma parte aérea mais compacta e com maior poder de sombreamento das entre linhas. Agostinho et al. (2006), trabalhando com cultivares de porte ereto e rasteiro verificaram que os cultivares de porte rasteiro foram mais sensíveis à interferência das plantas daninhas. Além disso, o espaçamento de semeadura também pode ter sido responsável por essas diferenças, já que em ambos os trabalhos o espaçamento entrelinhas utilizado foi de $90 \mathrm{~cm}$. Já nos trabalhos com as cultivares de porte ereto o espaçamento foi de $60 \mathrm{~cm}$.

ROMANINI Jr. (2007) constatou que a densidade de semeadura não influenciou na produção. Os resultados obtidos no presente trabalho estão de acordo com os obtidos por Carneiro (2006), que também não observou diferenças estatísticas significativas em relação à produtividade de amendoim em casca (kg/ha) por espaçamento, número de plantas por metro na linha e para a interação entre espaçamento e número de plantas por metro da cultivar IAC Runner 886. Esses resultados também foram encontrados por Bulgarelli (2008). Esses dados não se aplicam ao presente trabalho, uma vez que a população de plantas da cultura alterou significativamente a produção.

Com a cultivar IAC Runner 886, DIAS et al. (2009) obteve PAI no espaçamento de 0,80 m de 27 DAE e de 35 DAE no espaçamento de 0,90 m. CARDOZO et al. (2006) também no espaçamento de 0,90 m obtiveram um PAI de 29 DAE. NEPOMUCENO et al. (2006) trabalharam por dois anos consecutivos e determinaram um PAI de 23 DAE no primeiro ano e de 27 DAE no segundo ano. Porém, a perda tolerável causada pela interferência das plantas daninhas na produtividade da cultura varia de acordo com 
vários fatores, como custo de controle e perdas na colheita, sendo, portanto variável para cada situação (DIAS et al., 2009).

VELINI (1983), trabalhando com a cultura do arroz, verificou que a diminuição do espaçamento entrelinhas da cultura resultou em maior retenção de umidade nos períodos em que a transpiração foi intensa. Isso pode ter ocorrido neste trabalho, principalmente no mês de fevereiro, pois esse mês normalmente tem grande precipitação pluviométrica. Dessa forma, pode ter ocorrido maior deficiência hídrica nas plantas semeadas com $90 \mathrm{~cm}$ entrelinhas, ou seja, a diminuição do espaçamento favoreceu tanto as plantas daninhas como o amendoim.

Os parâmetros da equação sigmoidal de Boltzmann podem ser visualizados nas Tabelas 5 e 6 para os espaçamentos de 0,60 $\mathrm{m}$ e de $0,90 \mathrm{~m}$, respectivamente.

$\mathrm{Na}$ densidade de semeadura de 5 plantas. $\mathrm{m}^{-1}$ e espaçamento entre linhas de 0,60 m somente aos 87 DAE foi observada uma redução de $5 \%$ em relação a produção inicial, esse fato pode ser explicado pelo convívio da cultura com as plantas daninhas existentes nos tratamentos, uma vez que até os 45 DAE a tiririca era a espécie mais importante e esse fator pode explicar o baixo valor do parâmentro $d x(2,83)$ da equação de Boltzman, o que indica uma lenta perca na produção. Quando outras espécies com maior agressividade começam a ser observadas a cultura perde produção até que aos 104 DAE esta não é mais observada.

Já na densidade de semeadura de 10 plantas. $\mathrm{m}^{-1}$ a perda aceitável de $5 \%$ na produção se deu aos $39 \mathrm{DAE}$, e nesse caso perdas de produção ocorriam mais rapidamente, visto que o valor do parâmetro dx é 11,28. Embora até esse momento a cultura praticamente só conviveu com a tiririca. Dois fatores podem explicar essa perda de produção mais rápida. O primeiro é o inicio de uma competição intra-específica da própria cultura, embora essa densidade é a mais próxima da utilizada em produções comerciais, e outra é a severidade da comunidade infestante na competição com a cultura. Não mais foi observada produção aos 104 DAE. 
Tabela 5. Parâmetros da equação sigmoidal de Boltzman obtidos com a análise dos dados de produção do amendoim com casca para o espaçamento de $0,60 \mathrm{~m}$ e densidade de semeadura de 5, 10 e 15 plantas. $\mathrm{m}^{-1}$. Jaboticabal, SP, 2007/208.

\begin{tabular}{cccc}
\hline \multirow{2}{*}{ Parâmetro } & \multicolumn{3}{c}{$0,60 \mathrm{~m}$} \\
\cline { 2 - 4 } & 5 plantas $\cdot \mathrm{m}^{-1}$ & 10 plantas $\cdot \mathrm{m}^{-1}$ & 15 plantas $\cdot \mathrm{m}^{-1}$ \\
\hline $\mathrm{A}_{1}$ & 4627,53 & 5988,96 & 7610,31 \\
$\mathrm{~A}_{2}$ & -43 & -332 & -7512 \\
$\mathrm{X}_{0}$ & 94 & 71 & 120 \\
$\mathrm{Dx}$ & 2,83 & 11,28 & 50,38 \\
$\mathrm{R}^{2}$ & 0,91 & 0,97 & 0,97 \\
\hline \hline
\end{tabular}

Na densidade de 15 plantas. $\mathrm{m}^{-1}$ foi observada que aos 11 DAE a produção limite aceitável foi alcançada e essa velocidade na perda da produção pode ser justificada quando observamos o valor do parâmetro $d x$ que foi de 50,38 . Outro fator que pode explicar essa perda na produção é competição intra-específica pois embora pequena $\left(0,042 \mathrm{~kg} \cdot \mathrm{ha}^{-1}\right)$ obteve-se produção até o final do ciclo da cultura, então entende-se que, mesmo que a cultura competisse com ela mesma no início, depois de estabilizada a cultura, esta foi capaz de conviver com a comunidade infestante por todo seu ciclo.

No espaçamento de $0,90 \mathrm{~m}$ e densidade de semeadura de 5 plantas. $\mathrm{m}^{-1}$ a perda considerável como aceitável se deu aos 4 DAE e não mais foi observada produção aos 93 DAE. Durante esse período a cultura conviveu com plantas daninhas muito agressivas como o capim-colonião e o capim-colchão. $O$ valor do parâmetro $d x$ foi de 14,02 .

$\mathrm{Na}$ densidade de semeadura de 10 plantas $\mathrm{m}^{-1}$ foi observada perda de produção de $5 \%$ aos 41 DAE e não mais foi observada produção aos 107 DAE. Essa perda de produção não muito rápida pode ser explicada pelo valor intermediário do parâmetro $\mathrm{dx}$ de 19,58. Assim como na última densidade descrita, esses tratamentos conviveram durante esse período com plantas daninhas agressivas como, capim-colonião, capimcolchão e carrapicho-de-carneiro. 
$\mathrm{Na}$ densidade de semeadura de 15 plantas. $\mathrm{m}^{-1}$ o período limite para o convívio da cultura com a comunidade infestante foi 11 DAE e não mais foi observada produção aos 76 DAE. O fato de não mais haver produção muito antes das demais pode ser explicado pela competição intra-específica e também pela competição com a comunidade infestante já o valor do parâmetro $d x, 8,37$, não foi alto o suficiente para justificar perda tão rápida .

PITELLI (1985) fala que a importância da redução no espaçamento, em parte, está na precocidade do sombreamento promovido pela cultura.

Tabela 6. Parâmetros da equação sigmoidal de Boltzman obtidos com a análise dos dados de produção do amendoim com casca para o espaçamento de 0,90 m e densidade de semeadura de 5, 10 e 15 plantas. $\mathrm{m}^{-1}$. Jaboticabal, SP, $2007 / 208$.

\begin{tabular}{cccc}
\hline \multirow{2}{*}{ Parâmetro } & \multicolumn{3}{c}{$0,90 \mathrm{~m}$} \\
\cline { 2 - 4 } & 5 plantas. $\mathrm{m}^{-1}$ & 10 plantas. $\mathrm{m}^{-1}$ & 15 plantas $\cdot \mathrm{m}^{-1}$ \\
\hline $\mathrm{A}_{1}$ & 4967,92 & 5428,57 & 4599,49 \\
$\mathrm{~A}_{2}$ & -212 & -737 & -94 \\
$\mathrm{X}_{0}$ & 50 & 69 & 43 \\
$\mathrm{Dx}$ & 14,02 & 19,56 & 8,37 \\
$\mathrm{R}^{2}$ & 0,96 & 0,93 & 0,97 \\
\hline
\end{tabular}




\section{CONCLUSÕES}

Pelo relatado, pode-se concluir que independentemente do espaçamento e da densidade de semeadura, a tiririca foi à espécie de maior Importância Relativa (IR) durante o período inicial de desenvolvimento da cultura. O capim-colonião apresentou elevada IR aos 30 DAE devido a brotação de touceiras. O carrapicho-de-carneiro se destacava, na maioria das vezes, depois das outras espécies de plantas daninhas. No espaçamento de 0,90 m o capim-colchão foi a espécie de maior IR. No espaçamento de 0,60 m e densidade de semeadura de 5, 10 e 15 plantas. $\mathrm{m}^{-1}$, os PAls foram de 87,39 e $11 \mathrm{DAE}$, respectivamente, enquanto para o espaçamento de $0,90 \mathrm{~m}$ estes foram de 4 , 41 e 11 DAE. 


\section{REFERÊNCIAS}

AgOSTINHO, F.H., GRAVENA, R., ALVES, P.L.C.A., SALGADO, T.P., MATTOS, E.D. The effect of cultivar on Critical periods of weed control in peanuts. Peanut Science, v. 33, p. 29-35, 2006.

AGRIANUAL: Anuário da agricultura brasileira. São Paulo, FNP Consultoria e Agroinformativos, 2009, p.177-180.

ANDRIOLI, I.; CENTURION, J. F.; Levantamento detalhado dos solos da Faculdade de Ciências Agrárias e Veterinária de Jaboticabal. In: CONGRESSO BRASILEIRO DE CIÊNCIA DO SOLO, 27, Brasília, 1999. Resumos... Brasília: SBCS, 1999.

BIANCO, S. Matocompetição em amendoim "das secas" sob diferentes condições de adubação. 1978. 66 p. Monografia (Graduação em agronomia) - Universidade Estadual Paulista. 1978.

BARBOSA, L.M., PITELLI, R.A. Estudos sobre períodos de interferência de plantas daninhas na produtividade do amendoinzeiro (Arachis hypogaea L.). Hoehnea, v. 17, p.33-41, 1990.

BLANCO, H. G. A importância dos resultados ecológicos nos programas de controle de plantas daninhas. O Biológico, v. 38, p. 343-350, 1972.

BLEASDALE, J.K.A. Studies on plant competition. In: HARPER, J.L. (Ed.) The biology of weeds. Oxford: Blackweel Scientific, 1960, p.133-42.

BULGARELLI, E. M. B. Caracterização de variedades de amendoim cultivadas em diferentes populações. 2008. 61 p. Dissertação de mestrado (Mestrado em agronomia) - FCAV/UNESP -Jaboticabal, 2008. 
BRAZ, B. A., DURIGAN, J. C. Redução do espaçamento e subdosagens de herbicidas aplicados em pós emergência, para o controle de plantas daninhas, em soja (Glycine max). In: CONGRESSO BRASILEIRO DE CIÊNCIA DAS PLANTAS DANINHAS, 19, 1993, Londrina. Resumos... Londrina: SBCPD, 1993, p. 96-97.

CARDOZO, N. P., NEPOMUCENO, M., DIAS, T.C.S, ALVES, P. L. C. A., CASADEI, E. Interferência de plantas daninhas na cultura do amendoim em solo com trifluralina. In: ENCONTRO SOBRE A CULTURA DO AMENDOIM, 3., 2006, Jaboticabal. Anais... Jaboticabal: Faculdade de Ciências Agrárias e Veterinárias, 2006.

CARNEIRO, M. S. Influência do espaçamento no desenvolvimento do amendoim, cultivar Runner IAC 886. 2006. 53 p. (Trabalho de graduação em Agronomia).

CENTURION, M.A.P.C.; LEONEL, C.L.; CARNEIRO, M.S.; MOREIRA, L.F.; SILVA, I.A.B. Espaçamento do amendoim, cultivar IAC-886: Efeitos no crescimento de plantas. In Encontro sobre a cultura do amendoim, 2, 2005, Jaboticabal. Resumos... Jaboticabal: FUNEP, 2005 (CD-ROOM).

CENTURION, M.A.P.C.; LEONEL, C.L.; CARNEIRO, M.S.; MOREIRA, L.F.; MARTINS, R.M. Espaçamento do amendoim, cultivar IAC-886: Efeitos no rendimento, tamanho de grãos e produtividade. In Encontro sobre a cultura do amendoim, 2, 2005, Jaboticabal. Resumos... Jaboticabal: FUNEP, 2005 a (CD-ROOM).

COX, F. R.; REID, P. H. Interaction of plant population factors and level of production an the yield and grade of peanuts. Agronomy J ournal, v.57, 455-456, 1965.

CRUSCIOL, C. A. C.; SORATTO, R. P. Nutrição e produtividade do amendoim em sucessão ao cultivo de plantas de cobertura no sistema plantio direto. Pesquisa Agropecuária Brasileira, v. 42, n.11, p. 1553-1560, 2007. 
DEKKER, J., MEGGIT, W.F. Interference between velvetleaf (Abutilon theophast Medic.) and soybean (Glycine $\max$ (L.) Merr.) II. Population dynamics. Weed Res, v. 23, p. 103-107, 1983.

DEUBER, R. Ciência das plantas infestantes: fundamentos. Jaboticabal, FUNEP, 2003, 452 p.

DIAS, T.C.S.; ALVES, P.L.C.A.; PAVANI, M.C.M.D.; NEPOMUCENO, M. Efeito do espaçamento entre fileiras de amendoim rasteiro na interferência de plantas daninhas na cultura. Revista Planta Daninha, Viçosa-MG, v. 27, n. 2, p. 221-228, 2009.

DIAS, T.C.S.; ALVES, P.L.C.A.; NEPOMUCENO, M.; SOUZA JUNIOR, N.L.. Períodos de interferência das plantas daninhas sobre a cultura do amendoim(IAC-886). In: ENCONTRO SOBRE A CULTURA DO AMENDOIM, 2., 2005, Jaboticabal. Anais... Jaboticabal: Faculdade de Ciências Agrárias e Veterinárias, 2005.

DRENNAN, D.S.H.; JENNINGS, E.A. Weed competition in irrigated cotton (Gossypium barbadense L.) and groundnut (Arachis hypogaea L.) in the Sudan Gezira. Weed Res., v. 17, p. 3-9, 1977.

FEAKIM, S. D. Pest control in groundnuts. 3.ed. London: Center for Overseas Pest Research, 1973. 197 p.

FERNANDES, R. Programação de colheita de amendoim. Arranquio e Colheita (bateção). In Encontro sobre a cultura do amendoim, 1, 2004, Jaboticabal. Palestras... Jaboticabal: FUNEP, 2004 (CD-ROOM). 
FISCHER, R. A.; MILES, R. E. The role os spatial pattern in the competition between crop plants weeds. A theoretical analyses. Math. Biosci., v. 18, p. 335-350, 1973.

GAVIOLI, V.O. Efeitos da época de extensão do período de controle de plantas daninhas sobre a cultura do amendoim (Arachis hypogaea L.) em duas épocas de semeadura. Jaboticabal: FCAV/UNESP, 1985, 62 p. Trabalho de Graduação em Agronomia.

GODOY, I.J. Principais características dos cultivares IAC. Campinas: IAC, 2002. Folheto.

GODOY, I. J.; RODRIGUES FILHO, F. S. O.; GERIN, M. A. N. Amendoim. In: INSTITUTO AGRONÔMICO. Instruções agrícolas para o estado de São Paulo, 3. ed.Campinas, 1986. p. 23. (Boletim, 200).

GODOY, I. J.; MINOTTI, D.; RESENDE, P. L. Produção de amendoim de qualidade. Viçosa: Centro de Produções Técnicas, 2005. 168 p.

GRIME, J. P. Estrategias de adapatación de las plantas y procesos que controlan la Vegetación. Mexico, D.F.: Noriega, 1979. p. 79-87.

HAMMERTON, J. L. Weed control work in progress the University of the West Indies, Part 4. Pans (Pest Articles and New Summaries), London, v. 20, p. 429-436, 1974.

HAMMONS, R. O. Genetics of Arachis hypogaea. In: HAMMONS, R. O. Peanuts culture and uses. Stillwater: American Peanut Research and Education Association, 1973. p.135-173.

HILL, L.V.; SANTELMANN, P.W. Competitive effects of annual weeds on Spanish peanuts. Weed Sci., v. 17, p. 1-2, 1969. 
JUDD, W. S.; CAMPBELL, C. S.; KELLOGG, E. A.; STEVENS, P. F. Plant systematics: a phylogenetic approach. Massachusetts: Sinauer Associates, 1999. $464 p$.

KASAI, F.S., PAULO, E.M., CAVICHIOLI, J.C., PERESSIN, V.A., IGUE, T. Efeitos dos períodos de competição do mato na cultura do amendoim: I. Safra da seca de 1988. Bragantia, v.56, p.323-331, 1997.

KNAKE, E. L. Effect of sheade on giant foxtail. Weed Science, v. 20, n. 2, p. 588-592, 1972.

LASCA, D. H.C. Amendoim (Arachis hypogaea L.). In: Coordenadoria de assistência técnica integral. Manual técnico das culturas. Campinas, 1986. p.64-80 (Manual, 8).

LORENZI, H. Plantas daninhas do Brasil: terrestres, aquáticas, parasitas e tóxicas. 3 ed. Nova Odessa: Plantarum, 2000, 608 p.

LOURENZANI, W. L., LOURENZANI, A.E.B.S.; Perspectivas do agronegócio brasileiro de amendoim. Revista Informações Econômicas, SP, v.39, n.2, fev. 2009.

MARTINS, D. M.; PITELLI, R. A. Interferência das plantas daninhas na cultura do amendoim das águas: efeitos de espaçamentos, variedades e períodos de convivência. Planta Daninha, v. 12, n. 1, p. 87-92, 1994.

MAUN, M. A. Ecological effect of barnyard grass on soybeans in greenhouse. Weed Science, v. 25, n. 2, p. 128-131, 1977.

MUELLER-DOMBOIS, D., ELLEMBERG, H. Aims and methodos of vegetation ecology. New York: John Willey \& Sons, 1974. 547 p. 
NAKAGAWA, J.; NOJIMOTO, T.; ROSOLEM, C. A.; ALMEIDA A. M. de; LASCA, D. H. C. Efeitos da densidade de semeadura na produção de vagens de amendoim. Científica, São Paulo, v. 11, n. 1, p. 79-86, 1983.

NAKAGAWA, J.; LASCA, D. C.; NEVES, J. P. S.; NEVES, G. S.; SANCHES, S. V.; BARBOSA, V.; SILVA, M. N. e ROSSETO, C. A V. Efeito da densidade de semeadura 45 na produção do amendoim. Pesquisa Agropecuária Brasileira, Brasília, v.29, n.10, p. $1547-1555,1994$.

NEPOMUCENO, M., ALVES, P.L.C.A., DIAS, T.C.S., LUVEZUTI, R.A. Interferência das plantas daninhas na cultura do amendoim. In: ENCONTRO SOBRE A CULTURA DO AMENDOIM, 2., 2005, Jaboticabal. Anais... Jaboticabal: Faculdade de Ciências Agrárias e Veterinárias, 2005.

NEPOMUCENO, M., DIAS, T.C.S., ALVES, P.L.C.A., CARDOSO, G.D., MARCOLINI, L.W. Interferência das plantas daninhas na produção do amendoim, em dois anos consecutivos, na região de Jaboticabal. In: ENCONTRO SOBRE A CULTURA DO AMENDOIM, 3., 2006, Jaboticabal. Anais... Jaboticabal: Faculdade de Ciências Agrárias e Veterinárias, 2006.

NEPOMUCENO, M.P.; ALVES, P.L.C.A.; DIAS, T.C.S.; CARDOZO, N.P.; PAVANI, M.C.M.D.. Efeito da época de semeadura nas relações de interferência entre uma comunidade infestante e a cultura do amendoim. Revista Planta Daninha, Viçosa-MG, vol. 25, n. 3, p.481-488, 2007.

PACHECO, R. P. B. Duração do período de competição de plantas daninhas na cultura do amendoim-da-seca (Arachis hypogaea L.). Vegetalia, v. 3, n. 1, p. 1-11, 1980. 
PANSANI, L. C. Efeitos dos períodos de matocompetição sobre o crescimento e produtividade da cultura do amendoim das secas. Jaboticabal, 1983. 44 p. (Trabalho de graduação) - FCAV/UNESP, 1983.

PITELLI, R.A. Efeitos do período de competição das plantas daninhas sobre a produtividade do amendoim (A rachis hypogaea L.) e o teor de macronutrientes em suas sementes. 1980. 89 p. Tese (Doutorado em Fitotecnia) - Universidade de São Paulo. 1980.

PITELLI, R.A. Interferência das plantas daninhas nas culturas agrícolas. Inf. Agropec., Belo Horizonte, v.11, n. 29, p. 16-27, 1985.

PITELLI, R. A. Competição e controle de plantas daninhas em áreas agrícolas. IPEF, Piracicaba, v. 4, n. 12, p. 25-35, 1987.

PITELLI, R.A; FERRAZ, E.C.; MARINIS, G. Efeito do período de matocompetição sobre a produtividade do amendoim (Arachis hypogaea L.). Planta Daninha, v. 4, p. 110-119, 1981.

PITELLI, R.A., PERESSIM, V.A., PANSINI, L.C., PERECIN, D. Efeitos de períodos de convivência das plantas danihas sobre a produtividade da cultura do amendoim das secas. Planta Daninha, v. 7, p. 58-64, 1984.

PITELLI, R. A; DURIGAN, J. C. Terminologia para períodos de controle e de convivência das plantas daninhas em culturas anuais e bianuais. In: CONGRESSO BRASILEIRO DE HERBICIDAS E PLANTAS DANINHAS, 15, 1984, Belo Horizonte. Resumos... Belo Horizonte: SBHED, 1984. p. 37. 
PITELLI, R.A., GAVIOLI, V.D., GRAVENA, R., ROSSI, C.A. Efeito de período de controle de plantas daninhas na cultura de amendoim. Planta Daninha, v. 20, p. 389397, 2002.

PITELLI, R. A. O período anterior à interferência subseqüente (PAIS), uma nova abordagem para o manejo de plantas daninhas em culturas geneticamentes modificadas para a tolerância aos herbicidas não seletivos e sem residual. In: CONGRESSO BRASILEIRO DE CIÊNCIA DAS PLANTAS DANINHAS, 25, 2006, Brasília. Resumos... Brasília: SBCPD, 2006.

PITELLI, R.A.; MARCHI, S.R. Interferência das plantas invasoras nas áreas de reflorestamento. In: SEMINÁRIO TÉCNICO SOBRE PLANTAS DANINHAS E O USO DE HERBICIDAS EM REFLORESTAMENTO, 1., 1991, Rio de Janeiro. Anais... Rio de Janeiro: 1991. p.110-23, 1991.

RADOSEVICH, S. R., HOLT, J. S. Weed ecology: implications for vegetation management. Nova lorque: John Wiley \& Sons, 1984. 263 p.

SANTOS, R. C.; MELO FILHO, P. A.; BRITO, S. F. M.; MORAES, J. S. Fenologia de genótipos de amendoim dos tipos botânicos Valência e Virgínia. Pesquisa Agropecuária Brasileira, Brasília, v. 32, n. 6, p. 607-612, 1997.

SANTOS, C. R.; GODOY, I. J.; FÁVERO, P. A. Melhoramento do amendoim. In: O Agronegócio do amendoim no Brasil. EMBRAPA, 2005. 144 p.

ROMANINI JUNIOR, A. Influência do espaçamento de plantas no crescimento, produtividade e rendimento do amendoim rasteiro, cultivar runner IAC 886. 2007. 60 p. Dissertação de mestrado (Mestrado em agronomia) - FCAV/UNESP - Jaboticabal, 2007. 
ROMANINI JUNIOR, A.; LEONEL, C.L.; CARNEIRO, M. S.; CENTURION, M.A.P.C.; SILVA NETO, H.F.; Espaçamento do amendoim cultivar RUNNER IAC-886: efeitos no crescimento da planta e produtividade no município d Boroborema-SP, ano agrícola 2005/06. In: ENCONTRO SOBRE A CULTURA DO AMENDOIM, 3., 2006, Jaboticabal. Anais... Jaboticabal: Faculdade de Ciências Agrárias e Veterinárias, 2006.

SOUZA JUNIOR, N.L., NEPOMUCENO, M., ALVES, P.L.C.A., CARDOSO, N.P., PAVANI, M.C.M.D. Interferência das plantas daninhas No amendoinzeiro, em área de renovação de canavial, em dois anos consecutivos. In: ENCONTRO SOBRE A CULTURA DO AMENDOIM, 3., 2006, Jaboticabal. Anais... Jaboticabal: Faculdade de Ciências Agrárias e Veterinárias, 2006.

TASSO JUNIOR, L. C.; MARQUES, M. O.; NOGUEIRA, G. A. A cultura do amendoim. Jaboticabal: Editora FUNEP, 2004. p. 1-220.

VELINI, E. D. Matocompetição em arroz de sequeiro (Oryza sativa L.): Efeitos do espaçamento, doses de adubação fosfatada e períodos de controle das plantas daninhas. 1983. 80 p. Monografia (Graduação em agronomia) - Universidade Estadual Paulista, 1983.

XAVIER, F. E.; PINTO, J. J. O. Redução da dosagem do herbicida, em pós-emergência, em função da utilização de menores espaçamentos de semeadura da soja. In: CONGRESSO BRASILEIRO DE HERBICIDAS E PLANTS DANINHAS, 17, 1988, Piracicaba. Resumos... Piracicaba: SBHPD, 1988.

YADAV, S. K.; SINGH, S. P.; BHAN, V. M. Crop-weed competition studies in groundnut (Arachis hypogaea L.). The J ournal of Agricultural Science, v. 103, n. 2, p. 373-376, 1984. 
http://ciagri.iea.sp.gov.br/bancoiea/subjetiva.aspx?cod_sis=1 acessado em 15 de julho de 2009.

http://ciagri.iea.sp.gov.br/bancoiea/vp.aspx?cod_sis=15 acessado em 15 de julho de 2009.

AcroPDF - A Quality PDF Writer and PDF Converter to create PDF files. To remove the line, buy a license. 


\section{APÊNDICE}

Tabela 5A. Resultados da análise fitossociológica da comunidade infestante da cultura do amendoim no espaçamento de $0,60 \mathrm{~m}$ e densidade de semeadura de 5 plantas $\cdot \mathrm{m}^{-1}$.

\begin{tabular}{|c|c|c|c|c|c|}
\hline Espécies & $\begin{array}{c}\text { Densidade } \\
\text { Relativa }\end{array}$ & $\begin{array}{c}\text { Frequência } \\
\text { Relativa }\end{array}$ & $\begin{array}{c}\text { Dominância } \\
\text { Relativa }\end{array}$ & IVI & $\begin{array}{c}\text { Importância } \\
\text { Relativa }\end{array}$ \\
\hline \multicolumn{6}{|c|}{$15 \mathrm{DAE}$} \\
\hline Apaga-fogo & 26,87 & 18,75 & 5,31 & 50,92 & 16,97 \\
\hline Trapoeraba & 4,48 & 6,25 & 1,43 & 12,16 & 4,05 \\
\hline Capim-pé-de-galinha & 1,49 & 6,25 & 1,84 & 9,58 & 3,19 \\
\hline Capim-carrapicho & 2,99 & 12,50 & 0,82 & 16,30 & 5,43 \\
\hline Tiririca & 58,21 & 37,50 & 89,39 & 185,10 & 61,70 \\
\hline Anileira & 1,49 & 6,25 & 0,20 & 7,95 & 2,65 \\
\hline \multicolumn{6}{|c|}{$30 \mathrm{DAE}$} \\
\hline Apaga-fogo & 8,33 & 13,64 & 22,38 & 44,35 & 14,78 \\
\hline Trapoeraba & 3,79 & 9,09 & 0,79 & 13,67 & 4,56 \\
\hline Capim-colonião & 13,64 & 13,64 & 53,16 & 80,44 & 26,81 \\
\hline Capim-colchão & 2,27 & 4,55 & 3,01 & 9,83 & 3,28 \\
\hline Corda-de-viola & 3,03 & 6,82 & 1,82 & 11,67 & 3,89 \\
\hline Erva-de-touro & 0,76 & 2,27 & 1,33 & 4,36 & 1,45 \\
\hline Beldroega & 3,03 & 4,55 & 0,03 & 7,60 & 2,53 \\
\hline Carrapicho-de-carneiro & 33,33 & 13,64 & 11,24 & 58,21 & 19,40 \\
\hline Capim-carrapicho & 11,36 & 13,64 & 5,23 & 30,23 & 10,08 \\
\hline Mentrasto & 0,76 & 2,27 & 0,10 & 3,13 & 1,04 \\
\hline Tiririca & 6,82 & 6,82 & 0,74 & 14,37 & 4,79 \\
\hline Anileira & 4,55 & 4,55 & 0,01 & 9,10 & 3,03 \\
\hline Capim-braquiária & 8,33 & 4,55 & 0,15 & 13,03 & 4,34 \\
\hline \multicolumn{6}{|c|}{$45 \mathrm{DAE}$} \\
\hline Apaga-fogo & 1,71 & 3,13 & 5,62 & 10,46 & 3,49 \\
\hline Trapoeraba & 2,56 & 6,25 & 1,84 & 10,66 & 3,55 \\
\hline Capim-colchão & 8,55 & 9,38 & 7,73 & 25,66 & 8,55 \\
\hline Caruru & 1,71 & 3,13 & 9,87 & 14,71 & 4,90 \\
\hline Capim-pé-de-galinha & 4,27 & 6,25 & 2,40 & 12,92 & 4,31 \\
\hline Nabiça & 4,27 & 9,38 & 3,19 & 16,84 & 5,61 \\
\hline Carrapicho-de-carneiro & 7,69 & 12,50 & 8,27 & 28,46 & 9,49 \\
\hline Capim-carrapicho & 23,93 & 12,50 & 25,00 & 61,43 & 20,48 \\
\hline Tiririca & 37,61 & 12,50 & 28,51 & 78,62 & 26,21 \\
\hline Anileira & 1,71 & 6,25 & 2,01 & 9,97 & 3,32 \\
\hline
\end{tabular}


Tabela 5 A. continuação...

\begin{tabular}{|c|c|c|c|c|c|}
\hline Losna branca & 0,85 & 3,13 & 0,98 & 4,96 & 1,65 \\
\hline Beldroega & 5,13 & 15,63 & 4,56 & 25,32 & 8,44 \\
\hline & \multicolumn{5}{|c|}{$60 \mathrm{DAE}$} \\
\hline Apaga-fogo & 10,20 & 16,67 & 9,70 & 36,57 & 12,19 \\
\hline Capim-colonião & 4,08 & 11,11 & 8,22 & 23,41 & 7,80 \\
\hline Capim-colchão & 18,37 & 11,11 & 9,56 & 39,04 & 13,01 \\
\hline Caruru & 2,04 & 5,56 & 3,91 & 11,50 & 3,83 \\
\hline Capim-pé-de-galinha & 40,82 & 16,67 & 52,94 & 110,43 & 36,81 \\
\hline Carrapicho-de-carneiro & 18,37 & 22,22 & 10,01 & 50,60 & 16,87 \\
\hline Losna branca & 2,04 & 5,56 & 1,93 & 9,53 & 3,18 \\
\hline Capim-braquiária & 2,04 & 5,56 & 2,89 & 10,49 & 3,50 \\
\hline \multirow[t]{2}{*}{ Beldroega } & 2,04 & 5,56 & 0,83 & 8,43 & 2,81 \\
\hline & \multicolumn{5}{|c|}{$75 \mathrm{DAE}$} \\
\hline Apaga-fogo & 6,25 & 9,09 & 7,45 & 22,79 & 7,60 \\
\hline Trapoeraba & 3,13 & 9,09 & 1,57 & 13,79 & 4,60 \\
\hline Capim-colchão & 25,00 & 18,18 & 30,66 & 73,85 & 24,62 \\
\hline Caruru & 3,13 & 9,09 & 0,87 & 13,09 & 4,36 \\
\hline Capim-pé-de-galinha & 31,25 & 18,18 & 43,61 & 93,04 & 31,01 \\
\hline Carrapicho-de-carneiro & 12,50 & 18,18 & 14,77 & 45,46 & 15,15 \\
\hline Tiririca & 15,63 & 9,09 & 0,96 & 25,67 & 8,56 \\
\hline \multirow[t]{2}{*}{ Anileira } & 3,13 & 9,09 & 0,10 & 12,32 & 4,11 \\
\hline & \multicolumn{5}{|c|}{$90 \mathrm{DAE}$} \\
\hline Apaga-fogo & 8,51 & 16,67 & 7,63 & 32,81 & 10,94 \\
\hline Capim-colonião & 10,64 & 16,67 & 25,43 & 52,73 & 17,58 \\
\hline Capim-colchão & 6,38 & 5,56 & 6,49 & 18,43 & 6,14 \\
\hline Caruru & 2,13 & 5,56 & 2,29 & 9,97 & 3,32 \\
\hline Capim-pé-de-galinha & 46,81 & 22,22 & 27,25 & 96,28 & 32,09 \\
\hline Carrapicho-de-carneiro & 21,28 & 22,22 & 20,22 & 63,71 & 21,24 \\
\hline Pega-pega & 2,13 & 5,56 & 2,35 & 10,03 & 3,34 \\
\hline \multirow[t]{2}{*}{ Carrapichão } & 2,13 & 5,56 & 8,35 & 16,04 & 5,35 \\
\hline & \multicolumn{5}{|c|}{$105 \mathrm{DAE}$} \\
\hline Capim-colonião & 33,33 & 50,00 & 77,40 & 160,73 & 53,58 \\
\hline \multirow[t]{2}{*}{ Caruru } & 66,67 & 50,00 & 22,60 & 139,27 & 46,42 \\
\hline & \multicolumn{5}{|c|}{$120 \mathrm{DAE}$} \\
\hline Capim-colonião & 28,57 & 33,33 & 57,14 & 119,05 & 39,68 \\
\hline Caruru & 42,86 & 33,33 & 36,90 & 113,10 & 37,70 \\
\hline Capim-pé-de-galinha & 14,29 & 16,67 & 4,17 & 35,12 & 11,71 \\
\hline Carrapicho-de-carneiro & 14,29 & 16,67 & 1,79 & 32,74 & 10,91 \\
\hline
\end{tabular}


Tabela 5B. Resultados da análise fitossociológica da comunidade infestante da cultura do amendoim no espaçamento de 0,60 m e densidade de semeadura de 10 plantas. $\mathrm{m}^{-1}$.

\begin{tabular}{|c|c|c|c|c|c|}
\hline Espécies & $\begin{array}{l}\text { Densidade } \\
\text { Relativa }\end{array}$ & $\begin{array}{c}\text { Frequência } \\
\text { Relativa }\end{array}$ & $\begin{array}{l}\text { Dominância } \\
\text { Relativa }\end{array}$ & IVI & $\begin{array}{c}\text { Importância } \\
\text { Relativa }\end{array}$ \\
\hline \multicolumn{6}{|c|}{$15 \mathrm{DAE}$} \\
\hline Trapoeraba & 1,35 & 11,11 & 0,05 & 12,51 & 4,17 \\
\hline Corda-de-viola & 1,35 & 11,11 & 0,10 & 12,56 & 4,19 \\
\hline Nabiça & 2,70 & 11,11 & 0,15 & 13,96 & 4,65 \\
\hline Tiririca & 94,59 & 66,67 & 99,71 & 260,97 & 86,99 \\
\hline \multicolumn{6}{|c|}{$30 \mathrm{DAE}$} \\
\hline Apaga-fogo & 7,87 & 13,51 & 0,35 & 21,73 & 7,24 \\
\hline Trapoeraba & 4,49 & 5,41 & 0,55 & 10,45 & 3,48 \\
\hline Capim-colonião & 16,85 & 16,22 & 95,01 & 128,08 & 42,69 \\
\hline Capim-pé-degalinha & 4,49 & 5,41 & 0,14 & 10,04 & 3,35 \\
\hline Beldroega & 2,25 & 5,41 & 0,01 & 7,66 & 2,55 \\
\hline Nabiça & 1,12 & 2,70 & 0,00 & 3,83 & 1,28 \\
\hline Carrapicho-de-carneiro & 23,60 & 16,22 & 3,08 & 42,89 & 14,30 \\
\hline Capim-carrapicho & 1,12 & 2,70 & 0,61 & 4,44 & 1,48 \\
\hline Tiririca & 21,35 & 10,81 & 0,23 & 32,39 & 10,80 \\
\hline Anileira & 8,99 & 10,81 & 0,00 & 19,80 & 6,60 \\
\hline Losna branca & 3,37 & 5,41 & 0,00 & 8,78 & 2,93 \\
\hline Capim-braquiária & 4,49 & 5,41 & 0,01 & 9,91 & 3,30 \\
\hline \multicolumn{6}{|c|}{$45 \mathrm{DAE}$} \\
\hline Apaga-fogo & 6,35 & 11,11 & 9,29 & 26,75 & 8,92 \\
\hline Trapoeraba & 1,59 & 3,70 & 0,94 & 6,23 & 2,08 \\
\hline Capim-colchão & 14,29 & 14,81 & 19,35 & 48,45 & 16,15 \\
\hline Caruru & 6,35 & 7,41 & 7,82 & 21,58 & 7,19 \\
\hline Nabiça & 4,76 & 11,11 & 6,10 & 21,97 & 7,32 \\
\hline Capim-carrapicho & 7,94 & 11,11 & 6,82 & 25,87 & 8,62 \\
\hline Capim-carrapicho & 26,98 & 11,11 & 23,89 & 61,98 & 20,66 \\
\hline Tiririca & 23,81 & 14,81 & 19,80 & 58,43 & 19,48 \\
\hline Losna branca & 4,76 & 7,41 & 0,84 & 13,01 & 4,34 \\
\hline Beldroega & 3,17 & 7,41 & 5,15 & 15,73 & 5,24 \\
\hline \multicolumn{6}{|c|}{$60 \mathrm{DAE}$} \\
\hline Apaga-fogo & 5,56 & 3,45 & 3,08 & 12,09 & 4,03 \\
\hline Trapoeraba & 2,78 & 6,90 & 1,66 & 11,33 & 3,78 \\
\hline Capim-colonião & 2,78 & 6,90 & 5,25 & 14,92 & 4,97 \\
\hline Capim-colchão & 16,67 & 20,69 & 27,92 & 65,28 & 21,76 \\
\hline Capim-pé-degalinha & 25,00 & 13,79 & 24,93 & 63,73 & 21,24 \\
\hline
\end{tabular}


Tabela 5B. continuação...

\begin{tabular}{|c|c|c|c|c|c|}
\hline Nabiça & 4,17 & 10,34 & 3,42 & 17,93 & 5,98 \\
\hline Carrapicho-de-carneiro & 9,72 & 17,24 & 19,93 & 46,89 & 15,63 \\
\hline Capim-carrapicho & 1,39 & 3,45 & 2,50 & 7,34 & 2,45 \\
\hline Tiririca & 29,17 & 10,34 & 3,40 & 42,91 & 14,30 \\
\hline Anileira & 1,39 & 3,45 & 0,35 & 5,18 & 1,73 \\
\hline Carrapichão & 1,39 & 3,45 & 7,56 & 12,40 & 4,13 \\
\hline \multicolumn{6}{|c|}{$75 \mathrm{DAE}$} \\
\hline Apaga-fogo & 4,86 & 13,64 & 5,10 & 23,60 & 7,87 \\
\hline Trapoeraba & 4,32 & 4,55 & 0,26 & 9,13 & 3,04 \\
\hline Leiteiro & 1,08 & 4,55 & 0,82 & 6,45 & 2,15 \\
\hline Capim-colonião & 19,46 & 13,64 & 32,08 & 65,17 & 21,72 \\
\hline Capim-colchão & 9,19 & 13,64 & 12,07 & 34,89 & 11,63 \\
\hline Corda-de-viola & 2,16 & 9,09 & 0,37 & 11,62 & 3,87 \\
\hline Caruru & 1,62 & 4,55 & 3,33 & 9,50 & 3,17 \\
\hline Capim-pé-degalinha & 5,41 & 6,82 & 14,03 & 26,26 & 8,75 \\
\hline Nabiça & 0,54 & 2,27 & 0,55 & 3,36 & 1,12 \\
\hline Capim-carrapicho & 41,62 & 13,64 & 21,52 & 76,78 & 25,59 \\
\hline Carrapicho-de-carneiro & 2,16 & 2,27 & 4,21 & 8,65 & 2,88 \\
\hline Guanxamu & 0,54 & 2,27 & 0,09 & 2,90 & 0,97 \\
\hline Tiririca & 5,41 & 2,27 & 1,15 & 8,82 & 2,94 \\
\hline Anileira & 0,54 & 2,27 & 0,41 & 3,22 & 1,07 \\
\hline Carrapichão & 0,54 & 2,27 & 3,53 & 6,35 & 2,12 \\
\hline Losna branca & 0,54 & 2,27 & 0,50 & 3,31 & 1,10 \\
\hline & \multicolumn{5}{|c|}{$90 \mathrm{DAE}$} \\
\hline Apaga-fogo & 8,82 & 10,00 & 5,26 & 24,09 & 8,03 \\
\hline Leiteiro & 2,94 & 5,00 & 0,71 & 8,66 & 2,89 \\
\hline Capim-colonião & 14,71 & 15,00 & 29,67 & 59,38 & 19,79 \\
\hline Capim-colchão & 32,35 & 25,00 & 23,66 & 81,01 & 27,00 \\
\hline Caruru & 2,94 & 5,00 & 4,96 & 12,90 & 4,30 \\
\hline Capim-pé-degalinha & 8,82 & 5,00 & 2,84 & 16,67 & 5,56 \\
\hline Carrapicho-de-carneiro & 23,53 & 25,00 & 17,17 & 65,69 & 21,90 \\
\hline Carrapichão & 5,88 & 10,00 & 15,72 & 31,61 & 10,54 \\
\hline \multicolumn{6}{|c|}{$105 \mathrm{DAE}$} \\
\hline Panicum maximun & 10,00 & 11,11 & 17,54 & 38,65 & 12,88 \\
\hline Digitaria ssp. & 20,00 & 22,22 & 20,85 & 63,08 & 21,03 \\
\hline Amaranthus spp. & 20,00 & 11,11 & 18,96 & 50,07 & 16,69 \\
\hline Eleusine indica & 30,00 & 33,33 & 20,38 & 83,71 & 27,90 \\
\hline Carrapicho-de-carneiro & 20,00 & 22,22 & 22,27 & 64,50 & 21,50 \\
\hline \multicolumn{6}{|c|}{$120 \mathrm{DAE}$} \\
\hline
\end{tabular}


Tabela 5B. continuação...

\begin{tabular}{|c|c|c|c|c|c|}
\hline Capim-colchão & 20,00 & 20,00 & 9,62 & 49,62 & 16,54 \\
\hline Caruru & 40,00 & 40,00 & 46,15 & 126,15 & 42,05 \\
\hline Carrapicho-de-carneiro & 20,00 & 20,00 & 32,69 & 72,69 & 24,23 \\
\hline Anileira & 20,00 & 20,00 & 11,54 & 51,54 & 17,18 \\
\hline
\end{tabular}

Tabela 5C. Resultados da análise fitossociológica da comunidade infestante da cultura do amendoim no espaçamento de 0,60 m e densidade de semeadura de 15 plantas. $\mathrm{m}^{-1}$.

\begin{tabular}{|c|c|c|c|c|c|}
\hline Espécies & $\begin{array}{c}\text { Densidade } \\
\text { Relativa }\end{array}$ & $\begin{array}{c}\text { Frequência } \\
\text { Relativa }\end{array}$ & $\begin{array}{c}\text { Dominância } \\
\text { Relativa }\end{array}$ & IVI & $\begin{array}{c}\text { Importância } \\
\text { Relativa }\end{array}$ \\
\hline \multicolumn{6}{|c|}{$15 \mathrm{DAE}$} \\
\hline Nabiça & 2,35 & 12,50 & 0,16 & 15,01 & 5,00 \\
\hline Tiririca & 96,47 & 75,00 & 99,69 & 271,16 & 90,39 \\
\hline Carrapichão & 1,18 & 12,50 & 0,16 & 13,83 & 4,61 \\
\hline \multicolumn{6}{|c|}{$30 \mathrm{DAE}$} \\
\hline Apaga-fogo & 1,69 & 6,67 & 0,87 & 9,23 & 3,08 \\
\hline Trapoeraba & 5,08 & 6,67 & 1,14 & 12,89 & 4,30 \\
\hline Capim-pé-de-galinha & 5,08 & 6,67 & 3,02 & 14,77 & 4,92 \\
\hline Beldroega & 3,39 & 13,33 & 0,47 & 17,19 & 5,73 \\
\hline Nabiça & 5,08 & 13,33 & 1,14 & 19,56 & 6,52 \\
\hline Carrapicho-de-carneiro & 8,47 & 13,33 & 1,01 & 22,81 & 7,60 \\
\hline Quebra pedra & 1,69 & 6,67 & 0,07 & 8,43 & 2,81 \\
\hline Tiririca & 54,24 & 20,00 & 88,72 & 162,96 & 54,32 \\
\hline Anileira & 5,08 & 6,67 & 0,34 & 12,09 & 4,03 \\
\hline Capim-braquiária & 10,17 & 6,67 & 3,22 & 20,06 & 6,69 \\
\hline \multicolumn{6}{|c|}{$45 \mathrm{DAE}$} \\
\hline Apaga-fogo & 7,59 & 10,91 & 11,13 & 29,64 & 9,88 \\
\hline Trapoeraba & 1,27 & 3,64 & 0,93 & 5,84 & 1,95 \\
\hline Capim-colonião & 7,59 & 9,09 & 37,08 & 53,76 & 17,92 \\
\hline Capim-colchão & 4,43 & 5,45 & 3,52 & 13,41 & 4,47 \\
\hline Corda-de-viola & 12,66 & 10,91 & 7,82 & 31,38 & 10,46 \\
\hline Caruru & 0,63 & 1,82 & 0,13 & 2,59 & 0,86 \\
\hline Capim-pé-de-galinha & 2,53 & 3,64 & 1,81 & 7,98 & 2,66 \\
\hline Nabiça & 2,53 & 5,45 & 2,25 & 10,23 & 3,41 \\
\hline Carrapicho-de-carneiro & 27,85 & 10,91 & 18,23 & 56,99 & 19,00 \\
\hline Capim-carrapicho & 15,19 & 10,91 & 11,68 & 37,77 & 12,59 \\
\hline Mentrasto & 0,63 & 1,82 & 0,04 & 2,50 & 0,83 \\
\hline Tiririca & 6,96 & 10,91 & 2,69 & 20,56 & 6,85 \\
\hline Carrapicho rasteiro & 3,16 & 1,82 & 1,01 & 5,99 & 2,00 \\
\hline
\end{tabular}


Tabela 5C. continuação...

\begin{tabular}{|c|c|c|c|c|c|}
\hline Anileira & 3,16 & 5,45 & 0,48 & 9,09 & 3,03 \\
\hline Carrapichão & 1,90 & 1,82 & 0,19 & 3,90 & 1,30 \\
\hline Beldroega & 1,90 & 5,45 & 1,02 & 8,37 & 2,79 \\
\hline \multicolumn{6}{|c|}{$60 \mathrm{DAE}$} \\
\hline Apaga-fogo & 5,88 & 11,54 & 4,42 & 21,85 & 7,28 \\
\hline Capim-colonião & 7,06 & 11,54 & 9,32 & 27,91 & 9,30 \\
\hline Capim-colchão & 22,35 & 19,23 & 24,81 & 66,39 & 22,13 \\
\hline Caruru & 1,18 & 3,85 & 0,45 & 5,47 & 1,82 \\
\hline Capim-pé-de-galinha & 42,35 & 23,08 & 39,08 & 104,51 & 34,84 \\
\hline Carrapicho-de-carneiro & 15,29 & 19,23 & 14,60 & 49,13 & 16,38 \\
\hline Capim-carrapicho & 4,71 & 7,69 & 6,91 & 19,30 & 6,43 \\
\hline Anileira & 1,18 & 3,85 & 0,41 & 5,43 & 1,81 \\
\hline \multicolumn{6}{|c|}{$75 \mathrm{DAE}$} \\
\hline Apaga-fogo & 10,81 & 18,52 & 9,23 & 38,55 & 12,85 \\
\hline Trapoeraba & 5,41 & 7,41 & 1,04 & 13,85 & 4,62 \\
\hline Capim-colonião & 4,05 & 3,70 & 3,61 & 11,37 & 3,79 \\
\hline Capim-colchão & 24,32 & 22,22 & 19,39 & 65,93 & 21,98 \\
\hline Capim-pé-de-galinha & 37,84 & 18,52 & 47,01 & 103,36 & 34,45 \\
\hline Carrapicho-de-carneiro & 10,81 & 18,52 & 16,59 & 45,92 & 15,31 \\
\hline Anileira & 4,05 & 7,41 & 0,93 & 12,39 & 4,13 \\
\hline Capim-braquiária & 2,70 & 3,70 & 2,21 & 8,62 & 2,87 \\
\hline \multicolumn{6}{|c|}{$90 \mathrm{DAE}$} \\
\hline Apaga-fogo & 13,33 & 16,67 & 7,88 & 37,88 & 12,63 \\
\hline Capim-colonião & 6,67 & 11,11 & 13,53 & 31,30 & 10,43 \\
\hline Capim-colchão & 53,33 & 33,33 & 47,03 & 133,70 & 44,57 \\
\hline Carrapicho-de-carneiro & 23,33 & 33,33 & 26,98 & 83,64 & 27,88 \\
\hline Losna branca & 3,33 & 5,56 & 4,58 & 13,47 & 4,49 \\
\hline \multicolumn{6}{|c|}{$105 \mathrm{DAE}$} \\
\hline Apaga-fogo & 21,43 & 30,00 & 28,09 & 79,52 & 26,51 \\
\hline Capim-colchão & 28,57 & 30,00 & 44,38 & 102,95 & 34,32 \\
\hline Carrapicho-de-carneiro & 7,14 & 10,00 & 7,87 & 25,01 & 8,34 \\
\hline Anileira & 35,71 & 20,00 & 17,42 & 73,13 & 24,38 \\
\hline Losna branca & 7,14 & 10,00 & 2,25 & 19,39 & 6,46 \\
\hline \multicolumn{6}{|c|}{$120 \mathrm{DAE}$} \\
\hline Apaga-fogo & 12,50 & 12,50 & 9,27 & 34,27 & 11,42 \\
\hline Capim-colonião & 25,00 & 25,00 & 56,85 & 106,85 & 35,62 \\
\hline Capim-colchão & 12,50 & 12,50 & 9,27 & 34,27 & 11,42 \\
\hline Carrapicho-de-carneiro & 25,00 & 25,00 & 22,18 & 72,18 & 24,06 \\
\hline Anileira & 12,50 & 12,50 & 1,21 & 26,21 & 8,74 \\
\hline
\end{tabular}


Tabela 5C. continuação...

Losna branca

12,50

12,50

1,21

26,21

8,74

Tabela 6A. Resultados da análise fitossociológica da comunidade infestante da cultura do amendoim no espaçamento de $0,90 \mathrm{~m}$ e densidade de semeadura de 5 plantas. $\mathrm{m}^{-1}$.

\begin{tabular}{|c|c|c|c|c|c|}
\hline Espécies & $\begin{array}{c}\text { Densidade } \\
\text { Relativa }\end{array}$ & \begin{tabular}{|c|} 
Frequência \\
Relativa
\end{tabular} & $\begin{array}{c}\text { Dominância } \\
\text { Relativa }\end{array}$ & IVI & $\begin{array}{c}\text { Importância } \\
\text { Relativa }\end{array}$ \\
\hline \multicolumn{6}{|c|}{$15 \mathrm{DAE}$} \\
\hline Apaga-fogo & 23,33 & 27,27 & 4,32 & 54,93 & 18,31 \\
\hline Leiteiro & 3,33 & 9,09 & 0,86 & 13,29 & 4,43 \\
\hline Capim-pé-de-galinha & 3,33 & 9,09 & 2,31 & 14,73 & 4,91 \\
\hline Capim-carrapicho & 20,00 & 18,18 & 8,65 & 46,83 & 15,61 \\
\hline Tiririca & 43,33 & 27,27 & 83,00 & 153,60 & 51,20 \\
\hline Beldroega & 6,67 & 9,09 & 0,86 & 16,62 & 5,54 \\
\hline \multicolumn{6}{|c|}{$30 \mathrm{DAE}$} \\
\hline Apaga-fogo & 17,41 & 11,76 & 1,98 & 31,15 & 10,38 \\
\hline Trapoeraba & 1,99 & 5,88 & 0,46 & 8,33 & 2,78 \\
\hline Leiteiro & 0,50 & 1,96 & 0,03 & 2,49 & 0,83 \\
\hline Capim-colonião & 4,48 & 5,88 & 51,37 & 61,73 & 20,58 \\
\hline Capim-colchão & 3,98 & 5,88 & 14,82 & 24,69 & 8,23 \\
\hline Corda-de-viola & 3,48 & 7,84 & 5,05 & 16,38 & 5,46 \\
\hline Caruru & 0,99 & 3,92 & 0,05 & 4,97 & 1,66 \\
\hline Capim-pé-de-galinha & 3,98 & 3,92 & 0,16 & 8,06 & 2,69 \\
\hline Carrapicho-de-carneiro & 22,39 & 11,76 & 17,28 & 51,43 & 17,14 \\
\hline Capim-carrapicho & 11,44 & 11,76 & 3,65 & 26,86 & 8,95 \\
\hline Guanxuma & 1,49 & 1,96 & 0,66 & 4,11 & 1,37 \\
\hline Tiririca & 12,93 & 3,92 & 2,90 & 19,76 & 6,59 \\
\hline Beldroega & 3,48 & 7,84 & 0,40 & 11,73 & 3,91 \\
\hline Anileira & 1,99 & 5,88 & 0,41 & 8,29 & 2,76 \\
\hline Capim-braquiária & 9,45 & 9,80 & 0,78 & 20,04 & 6,68 \\
\hline \multicolumn{6}{|c|}{$45 \mathrm{DAE}$} \\
\hline Apaga-fogo & 20,63 & 16,67 & 20,18 & 57,48 & 19,16 \\
\hline Trapoeraba & 3,17 & 2,78 & 1,07 & 7,02 & 2,34 \\
\hline Leiteiro & 4,76 & 5,56 & 2,50 & 12,82 & 4,27 \\
\hline Capim-colchão & 17,46 & 13,89 & 16,15 & 47,50 & 15,83 \\
\hline Caruru & 3,17 & 5,56 & 6,12 & 14,85 & 4,95 \\
\hline Capim-pé-de-galinha & 3,17 & 5,56 & 6,30 & 15,03 & 5,01 \\
\hline Capim-carrapicho & 7,94 & 8,33 & 6,10 & 22,37 & 7,46 \\
\hline Capim-carrapicho & 25,40 & 16,67 & 23,91 & 65,98 & 21,99 \\
\hline
\end{tabular}

AcroPDF - A Quality PDF Writer and PDF Converter to create PDF files. To remove the line, buy a license. 
Tabela 6A. continuação...

\begin{tabular}{|c|c|c|c|c|c|}
\hline Beldroega & 3,17 & 5,56 & 5,68 & 14,41 & 4,80 \\
\hline Anileira & 4,76 & 8,33 & 4,81 & 17,91 & 5,97 \\
\hline Losna branca & 3,17 & 5,56 & 1,34 & 10,07 & 3,36 \\
\hline Nabo & 3,17 & 5,56 & 5,84 & 14,57 & 4,86 \\
\hline \multicolumn{6}{|c|}{$60 \mathrm{DAE}$} \\
\hline Apaga-fogo & 25,00 & 22,73 & 18,24 & 65,96 & 21,99 \\
\hline Leiteiro & 1,67 & 4,55 & 4,63 & 10,84 & 3,61 \\
\hline Capim-colchão & 46,67 & 22,73 & 38,06 & 107,45 & 35,82 \\
\hline Caruru & 5,00 & 4,55 & 7,43 & 16,98 & 5,66 \\
\hline Capim-pé-de-galinha & 1,67 & 4,55 & 15,64 & 21,86 & 7,29 \\
\hline Carrapicho-de-carneiro & 11,67 & 18,18 & 8,64 & 38,49 & 12,83 \\
\hline Capim-carrapicho & 1,67 & 4,55 & 2,04 & 8,25 & 2,75 \\
\hline Beldroega & 1,67 & 4,55 & 0,66 & 6,87 & 2,29 \\
\hline Anileira & 1,67 & 4,55 & 0,29 & 6,51 & 2,17 \\
\hline Carrapichão & 3,33 & 9,09 & 4,37 & 16,79 & 5,60 \\
\hline \multicolumn{6}{|c|}{$75 \mathrm{DAE}$} \\
\hline Apaga-fogo & 27,27 & 27,78 & 21,06 & 76,11 & 25,37 \\
\hline Capim-colchão & 27,27 & 16,67 & 9,13 & 53,07 & 17,69 \\
\hline Caruru & 6,06 & 5,56 & 4,87 & 16,49 & 5,50 \\
\hline Capim-pé-de-galinha & 6,06 & 5,56 & 5,60 & 17,22 & 5,74 \\
\hline Carrapicho-de-carneiro & 15,15 & 16,67 & 6,83 & 38,65 & 12,88 \\
\hline Capim-carrapicho & 6,06 & 11,11 & 12,69 & 29,86 & 9,95 \\
\hline Losna branca & 3,03 & 5,56 & 0,42 & 9,00 & 3,00 \\
\hline Carrapichão & 9,09 & 11,11 & 39,40 & 59,60 & 19,87 \\
\hline \multicolumn{6}{|c|}{$90 \mathrm{DAE}$} \\
\hline Apaga-fogo & 17,86 & 26,67 & 18,18 & 62,70 & 20,90 \\
\hline Capim-colonião & 7,14 & 13,33 & 31,32 & 51,79 & 17,26 \\
\hline Capim-colchão & 32,14 & 20,00 & 25,68 & 77,83 & 25,94 \\
\hline Caruru & 7,14 & 13,33 & 8,92 & 29,40 & 9,80 \\
\hline Capim-pé-de-galinha & 25,00 & 6,67 & 3,90 & 35,57 & 11,86 \\
\hline Carrapicho-de-carneiro & 10,71 & 20,00 & 12,00 & 42,71 & 14,24 \\
\hline \multicolumn{6}{|c|}{$105 \mathrm{DAE}$} \\
\hline Apaga-fogo & 35,00 & 25,00 & 31,14 & 91,14 & 30,38 \\
\hline Capim-colonião & 5,00 & 8,33 & 11,38 & 24,71 & 8,24 \\
\hline Capim-colchão & 20,00 & 16,67 & 21,56 & 58,22 & 19,41 \\
\hline Caruru & 5,00 & 8,33 & 0,90 & 14,23 & 4,74 \\
\hline Capim-pé-de-galinha & 5,00 & 8,33 & 3,59 & 16,93 & 5,64 \\
\hline Carrapicho-de-carneiro & 25,00 & 25,00 & 29,94 & 79,94 & 26,65 \\
\hline Losna branca & 5,00 & 8,33 & 1,50 & 14,83 & 4,94 \\
\hline
\end{tabular}


Tabela 6A. continuação...

\begin{tabular}{|c|c|c|c|c|c|}
\hline \multicolumn{7}{|c|}{$120 \mathrm{DAE}$} \\
\hline Apaga-fogo & 23,53 & 16,67 & 17,36 & 57,56 & 19,19 \\
\hline Capim-colonião & 11,76 & 16,67 & 36,01 & 64,44 & 21,48 \\
\hline Capim-colchão & 11,76 & 8,33 & 9,32 & 29,42 & 9,81 \\
\hline Caruru & 11,76 & 16,67 & 9,00 & 37,43 & 12,48 \\
\hline Carrapicho-de-carneiro & 35,29 & 33,33 & 27,65 & 96,28 & 32,09 \\
\hline Pega-pega & 5,88 & 8,33 & 0,64 & 14,86 & 4,95 \\
\hline
\end{tabular}

Tabela 6B. Resultados da análise fitossociológica da comunidade infestante da cultura do amendoim no espaçamento de $0,90 \mathrm{~m}$ e densidade de semeadura de 10 plantas. $\mathrm{m}^{-1}$.

\begin{tabular}{|c|c|c|c|c|c|}
\hline Espécies & $\begin{array}{c}\text { Densidade } \\
\text { Relativa }\end{array}$ & $\begin{array}{c}\text { Frequência } \\
\text { Relativa }\end{array}$ & $\begin{array}{l}\text { Dominância } \\
\text { Relativa }\end{array}$ & $\mathrm{IVI}$ & $\begin{array}{c}\text { Importância } \\
\text { Relativa }\end{array}$ \\
\hline \multicolumn{6}{|c|}{$15 \mathrm{DAE}$} \\
\hline Trapoeraba & 2,27 & 12,50 & 0,33 & 15,10 & 5,03 \\
\hline Capim-pé-de-galinha & 2,27 & 12,50 & 3,85 & 18,62 & 6,21 \\
\hline Tiririca & 95,45 & 75,00 & 95,82 & 266,28 & 88,76 \\
\hline \multicolumn{6}{|c|}{$30 \mathrm{DAE}$} \\
\hline Apaga-fogo & 13,43 & 13,33 & 0,09 & 26,86 & 8,95 \\
\hline Trapoeraba & 2,99 & 6,67 & 0,14 & 9,79 & 3,26 \\
\hline Capim-colonião & 26,87 & 16,67 & 92,49 & 136,03 & 45,34 \\
\hline Capim-colchão & 7,46 & 6,67 & 4,30 & 18,43 & 6,14 \\
\hline Fedegoso & 1,49 & 3,33 & 0,22 & 5,05 & 1,68 \\
\hline Carrapicho-de-carneiro & 10,45 & 13,33 & 1,68 & 25,46 & 8,49 \\
\hline Capim-carrapicho & 4,48 & 6,67 & 0,00 & 11,15 & 3,72 \\
\hline Gunaxuma & 2,99 & 6,67 & 1,02 & 10,67 & 3,56 \\
\hline Beldroega & 1,49 & 3,33 & 0,01 & 4,83 & 1,61 \\
\hline Anileira & 2,99 & 6,67 & 0,00 & 9,65 & 3,22 \\
\hline Nabiça & 10,45 & 6,67 & 0,02 & 17,14 & 5,71 \\
\hline Capim-braquiária & 14,93 & 10,00 & 0,01 & 24,94 & 8,31 \\
\hline \multicolumn{6}{|c|}{$45 \mathrm{DAE}$} \\
\hline Apaga-fogo & 18,57 & 12,82 & 25,17 & 56,56 & 18,85 \\
\hline Beldroega & 1,43 & 2,56 & 0,21 & 4,20 & 1,40 \\
\hline Capim-colchão & 4,29 & 5,13 & 1,90 & 11,32 & 3,77 \\
\hline Caruru & 1,43 & 2,56 & 1,13 & 5,12 & 1,71 \\
\hline Capim-pé-de-galinha & 7,14 & 7,69 & 19,18 & 34,01 & 11,34 \\
\hline Carrapicho-de-carneiro & 8,57 & 12,82 & 11,95 & 33,34 & 11,11 \\
\hline Capim-carrapicho & 10,00 & 10,26 & 11,40 & 31,66 & 10,55 \\
\hline Tiririca & 20,00 & 7,69 & 5,77 & 33,46 & 11,15 \\
\hline
\end{tabular}


Tabela 6B. continuação...

\begin{tabular}{|c|c|c|c|c|c|}
\hline Beldroega & 7,14 & 10,26 & 13,39 & 30,79 & 10,26 \\
\hline Anileira & 14,29 & 15,38 & 2,28 & 31,95 & 10,65 \\
\hline Losna branca & 2,86 & 5,13 & 0,93 & 8,92 & 2,97 \\
\hline Nabiça & 4,29 & 7,69 & 6,71 & 18,68 & 6,23 \\
\hline \multicolumn{6}{|c|}{$60 \mathrm{DAE}$} \\
\hline Apaga-fogo & 26,23 & 21,74 & 20,88 & 68,85 & 22,95 \\
\hline Trapoeraba & 1,64 & 4,35 & 0,74 & 6,73 & 2,24 \\
\hline Leiteiro & 1,64 & 4,35 & 0,80 & 6,79 & 2,26 \\
\hline Capim-colchão & 37,70 & 26,09 & 40,55 & 104,34 & 34,78 \\
\hline Caruru & 3,28 & 4,35 & 1,42 & 9,04 & 3,01 \\
\hline Capim-pé-de-galinha & 18,03 & 17,39 & 20,33 & 55,76 & 18,59 \\
\hline Carrapicho-de-carneiro & 6,56 & 8,70 & 6,80 & 22,06 & 7,35 \\
\hline Carrapichão & 1,64 & 4,35 & 7,23 & 13,21 & 4,40 \\
\hline Nabiça & 3,28 & 8,70 & 1,25 & 13,22 & 4,41 \\
\hline \multicolumn{6}{|c|}{$75 \mathrm{DAE}$} \\
\hline Apaga-fogo & 6,53 & 11,54 & 12,64 & 30,71 & 10,24 \\
\hline Capim-colonião & 17,09 & 11,54 & 25,26 & 53,89 & 17,96 \\
\hline Capim-colchão & 9,05 & 11,54 & 18,71 & 39,29 & 13,10 \\
\hline Corda-de-viola & 2,51 & 5,77 & 0,43 & 8,71 & 2,90 \\
\hline Caruru & 1,01 & 3,85 & 5,31 & 10,16 & 3,39 \\
\hline Capim-pé-de-galinha & 7,04 & 7,69 & 9,30 & 24,03 & 8,01 \\
\hline Carrapicho-de-carneiro & 26,63 & 11,54 & 11,21 & 49,39 & 16,46 \\
\hline Capim-carrapicho & 16,08 & 11,54 & 10,88 & 38,50 & 12,83 \\
\hline Gunaxuma & 7,54 & 9,62 & 0,70 & 17,86 & 5,95 \\
\hline Anileira & 4,02 & 7,69 & 1,32 & 13,03 & 4,34 \\
\hline Losna branca & 1,01 & 3,85 & 0,65 & 5,50 & 1,83 \\
\hline Nabiça & 0,50 & 1,92 & 0,41 & 2,84 & 0,95 \\
\hline Capim-braquiária & 1,01 & 1,92 & 3,17 & 6,09 & 2,03 \\
\hline \multicolumn{6}{|c|}{$90 \mathrm{DAE}$} \\
\hline Apaga-fogo & 20,00 & 22,22 & 12,36 & 54,59 & 18,20 \\
\hline Capim-colchão & 20,00 & 22,22 & 15,17 & 57,39 & 19,13 \\
\hline Caruru & 10,00 & 11,11 & 5,71 & 26,82 & 8,94 \\
\hline Capim-pé-de-galinha & 20,00 & 11,11 & 4,93 & 36,04 & 12,01 \\
\hline Carrapicho-de-carneiro & 10,00 & 11,11 & 4,02 & 25,13 & 8,38 \\
\hline Carrapichão & 20,00 & 22,22 & 57,81 & 100,03 & 33,34 \\
\hline \multicolumn{6}{|c|}{$105 \mathrm{DAE}$} \\
\hline Apaga-fogo & 18,18 & 12,50 & 18,93 & 49,61 & 16,54 \\
\hline Capim-colonião & 9,09 & 12,50 & 15,64 & 37,23 & 12,41 \\
\hline Capim-colchão & 27,27 & 25,00 & 13,17 & 65,44 & 21,81 \\
\hline
\end{tabular}


Tabela 6B. continuação...

\begin{tabular}{|c|c|c|c|c|c|}
\hline Caruru & 9,09 & 12,50 & 9,47 & 31,06 & 10,35 \\
\hline Carrapicho-de-carneiro & 27,27 & 25,00 & 32,92 & 85,19 & 28,40 \\
\hline Brenvilha & 9,09 & 12,50 & 9,88 & 31,47 & 10,49 \\
\hline \multicolumn{5}{|c|}{$120 \mathrm{DAE}$} \\
\hline Capim-colchão & 50,00 & 33,33 & 55,81 & 139,15 & 46,38 \\
\hline Caruru & 25,00 & 33,33 & 34,88 & 93,22 & 31,07 \\
\hline Anileira & 25,00 & 33,33 & 9,30 & 67,64 & 22,55 \\
\hline
\end{tabular}

Tabela 6C. Resultados da análise fitossociológica da comunidade infestante da cultura do amendoim no espaçamento de 0,90 m e densidade de semeadura de 15 plantas. $\mathrm{m}^{-1}$.

\begin{tabular}{|c|c|c|c|c|c|}
\hline Espécies & $\begin{array}{c}\text { Densidade } \\
\text { Relativa }\end{array}$ & $\begin{array}{c}\text { Frequência } \\
\text { Relativa }\end{array}$ & $\begin{array}{c}\text { Dominância } \\
\text { Relativa }\end{array}$ & IVI & $\begin{array}{c}\text { Importância } \\
\text { Relativa }\end{array}$ \\
\hline & \multicolumn{5}{|c|}{$15 \mathrm{DAE}$} \\
\hline Apaga-fogo & 36,84 & 27,27 & 10,98 & 75,09 & 25,03 \\
\hline Trapoeraba & 1,75 & 9,09 & 0,48 & 11,32 & 3,77 \\
\hline Capim-carrapicho & 17,54 & 18,18 & 10,50 & 46,23 & 15,41 \\
\hline \multirow{2}{*}{ Tiririca } & 43,86 & 45,45 & 78,04 & 167,36 & 55,79 \\
\hline & \multicolumn{5}{|c|}{$30 \mathrm{DAE}$} \\
\hline Apaga-fogo & 39,81 & 26,09 & 42,82 & 108,72 & 36,24 \\
\hline Trapoeraba & 1,94 & 4,35 & 1,30 & 7,59 & 2,53 \\
\hline Capim-colchão & 1,94 & 4,35 & 1,15 & 7,43 & 2,48 \\
\hline Caruru & 1,94 & 4,35 & 2,90 & 9,19 & 3,06 \\
\hline Capim-pé-de-galinha & 20,39 & 4,35 & 25,34 & 50,08 & 16,69 \\
\hline Carrapicho-de-caneiro & 4,85 & 8,70 & 6,64 & 20,19 & 6,73 \\
\hline Tiririca & 1,94 & 4,35 & 5,80 & 12,09 & 4,03 \\
\hline Beldroega & 1,94 & 8,70 & 0,53 & 11,17 & 3,72 \\
\hline Anileira & 0,97 & 4,35 & 0,15 & 5,47 & 1,82 \\
\hline Losna branca & 2,91 & 8,70 & 2,44 & 14,05 & 4,68 \\
\hline Nabiça & 0,97 & 4,35 & 0,38 & 5,70 & 1,90 \\
\hline \multirow[t]{2}{*}{ Capim-braquiária } & 20,39 & 17,39 & 10,53 & 48,31 & 16,10 \\
\hline & \multicolumn{5}{|c|}{$45 \mathrm{DAE}$} \\
\hline Apaga-fogo & 17,27 & 16,22 & 5,91 & 39,39 & 13,13 \\
\hline Trapoeraba & 4,32 & 8,11 & 1,68 & 14,11 & 4,70 \\
\hline Capim-colonião & 23,02 & 16,22 & 77,99 & 117,23 & 39,08 \\
\hline Capim-colchão & 3,60 & 10,81 & 2,81 & 17,21 & 5,74 \\
\hline Corda-de-viola & 7,91 & 8,11 & 0,76 & 16,78 & 5,59 \\
\hline Carrapicho-de-caneiro & 28,78 & 16,22 & 6,49 & 51,48 & 17,16 \\
\hline Capim-carrapicho & 12,95 & 16,22 & 4,00 & 33,16 & 11,05 \\
\hline
\end{tabular}


Tabela 6C. continuação...

\begin{tabular}{|c|c|c|c|c|c|}
\hline Guanxuma & 2,16 & 8,11 & 0,37 & 10,63 & 3,54 \\
\hline & \multicolumn{5}{|c|}{$60 \mathrm{DAE}$} \\
\hline Apaga-fogo & 28,89 & 24,00 & 31,48 & 84,37 & 28,12 \\
\hline Capim-colonião & 2,22 & 4,00 & 0,00 & 6,22 & 2,07 \\
\hline Capim-colchão & 22,22 & 16,00 & 12,80 & 51,02 & 17,01 \\
\hline Caruru & 6,67 & 12,00 & 6,01 & 24,68 & 8,23 \\
\hline Capim-pé-de-galinha & 11,11 & 12,00 & 7,15 & 30,26 & 10,09 \\
\hline Carrapicho-de-caneiro & 15,56 & 8,00 & 10,43 & 33,98 & 11,33 \\
\hline Pega-pega & 2,22 & 4,00 & 0,51 & 6,73 & 2,24 \\
\hline Losna branca & 4,44 & 8,00 & 7,24 & 19,69 & 6,56 \\
\hline Carrapichão & 4,44 & 8,00 & 18,37 & 30,81 & 10,27 \\
\hline \multirow[t]{2}{*}{ Capim-braquiária } & 2,22 & 4,00 & 6,01 & 12,23 & 4,08 \\
\hline & \multicolumn{5}{|c|}{$75 \mathrm{DAE}$} \\
\hline Apaga-fogo & 28,57 & 23,08 & 16,05 & 67,70 & 22,57 \\
\hline Capim-colonião & 5,36 & 11,54 & 7,09 & 23,98 & 7,99 \\
\hline Capim-colchão & 23,21 & 15,38 & 20,23 & 58,83 & 19,61 \\
\hline Caruru & 7,14 & 7,69 & 11,69 & 26,53 & 8,84 \\
\hline Capim-pé-de-galinha & 3,57 & 7,69 & 6,72 & 17,98 & 5,99 \\
\hline Caruru & 25,00 & 23,08 & 19,06 & 67,13 & 22,38 \\
\hline Pega-pega & 1,79 & 3,85 & 1,69 & 7,32 & 2,44 \\
\hline \multirow[t]{2}{*}{ Carrapichão } & 5,36 & 7,69 & 17,47 & 30,52 & 10,17 \\
\hline & \multicolumn{5}{|c|}{$90 \mathrm{DAE}$} \\
\hline Apaga-fogo & 13,04 & 20,00 & 14,64 & 47,68 & 15,89 \\
\hline Trapoeraba & 5,80 & 3,33 & 0,00 & 9,13 & 3,04 \\
\hline Capim-colonião & 5,80 & 13,33 & 18,92 & 38,05 & 12,68 \\
\hline Capim-colchão & 42,03 & 20,00 & 34,01 & 96,04 & 32,01 \\
\hline Caruru & 7,25 & 16,67 & 13,73 & 37,64 & 12,55 \\
\hline Carrapicho-de-caneiro & 23,19 & 20,00 & 17,99 & 61,18 & 20,39 \\
\hline Anileira & 1,45 & 3,33 & 0,22 & 5,00 & 1,67 \\
\hline \multirow[t]{2}{*}{ Losna branca } & 1,45 & 3,33 & 0,50 & 5,28 & 1,76 \\
\hline & \multicolumn{5}{|c|}{$105 \mathrm{DAE}$} \\
\hline Apaga-fogo & 11,11 & 16,67 & 8,22 & 36,00 & 12,00 \\
\hline Capim-colchão & 44,44 & 33,33 & 42,01 & 119,79 & 39,93 \\
\hline Carrapicho-de-caneiro & 22,22 & 33,33 & 21,00 & 76,56 & 25,52 \\
\hline \multirow[t]{2}{*}{ Carrapichão } & 22,22 & 16,67 & 28,77 & 67,66 & 22,55 \\
\hline & \multicolumn{5}{|c|}{$120 \mathrm{DAE}$} \\
\hline Apaga-fogo & 0,70 & 16,67 & 20,97 & 38,34 & 12,78 \\
\hline Capim-colchão & 2,11 & 16,67 & 31,88 & 50,66 & 16,89 \\
\hline Carrapicho-de-caneiro & 1,41 & 33,33 & 26,85 & 61,59 & 20,53 \\
\hline
\end{tabular}


Tabela 6C. continuação...

\begin{tabular}{|c|c|c|c|c|c|}
\hline Brenvilha & 0,70 & 16,67 & 20,13 & 37,51 & 12,50 \\
\hline Carrapichão & 95,07 & 16,67 & 0,17 & 111,90 & 37,30 \\
\hline
\end{tabular}




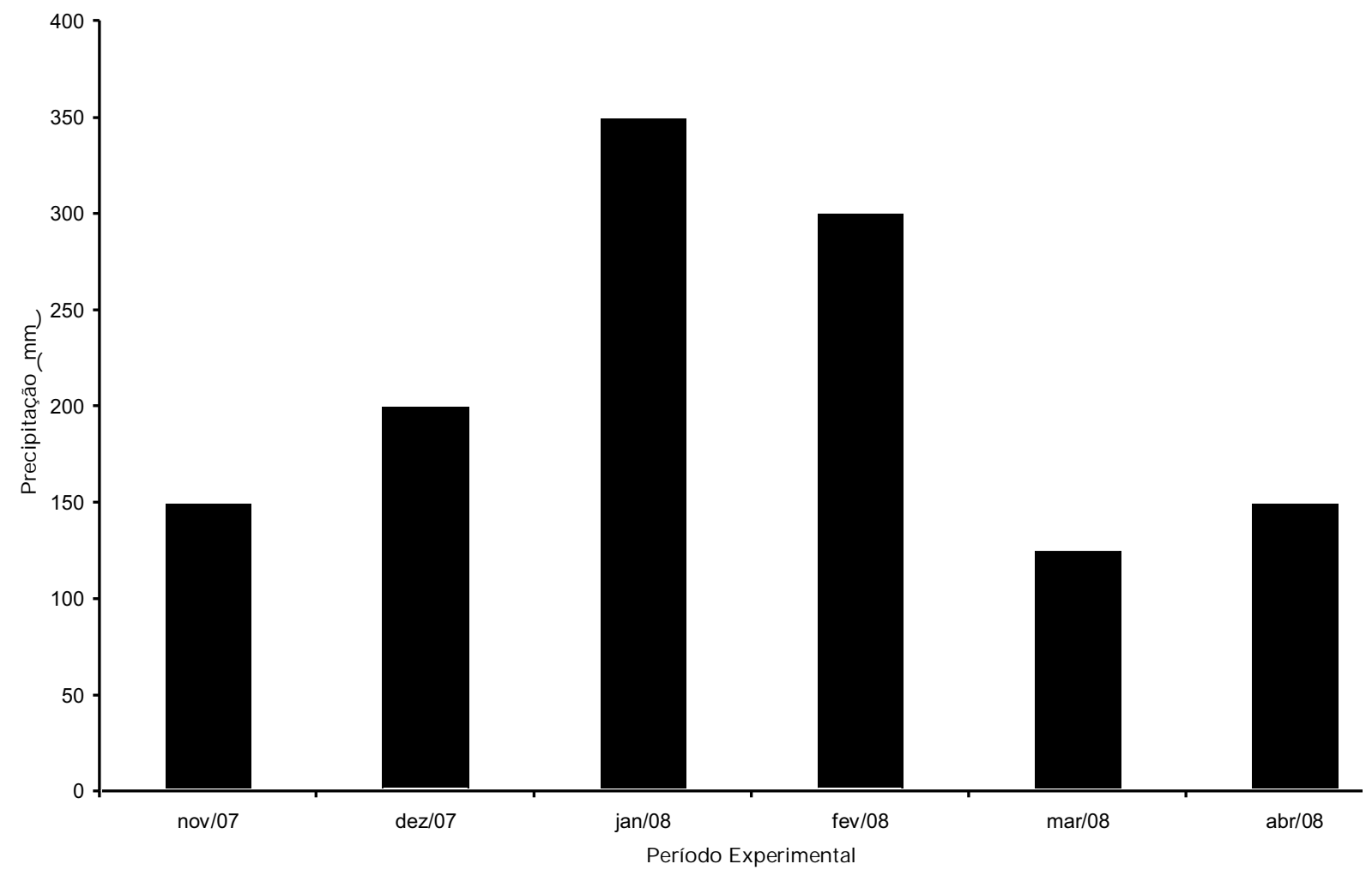

Figura 3A. Precipitação pluvial no decorrer do período experimental. Jaboticabal, SP, $2007 / 2008$. 

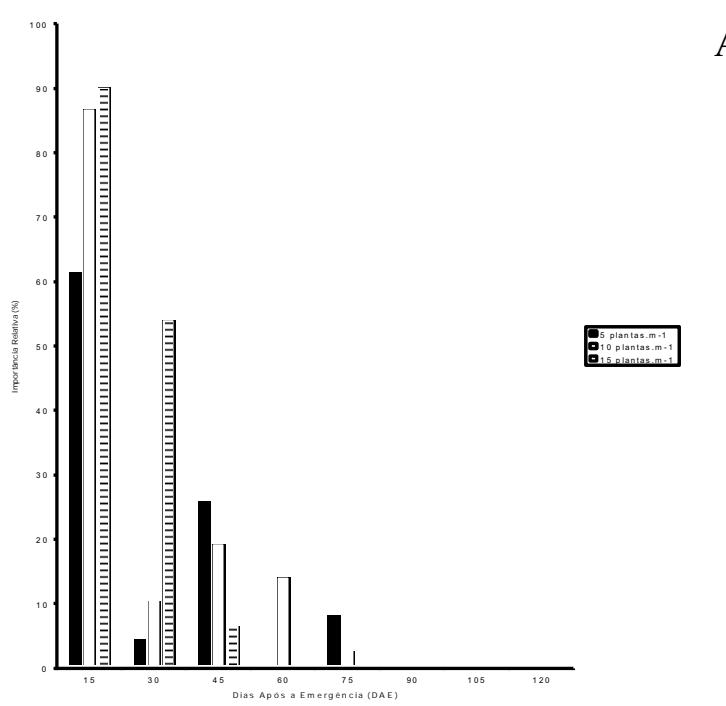

A

B
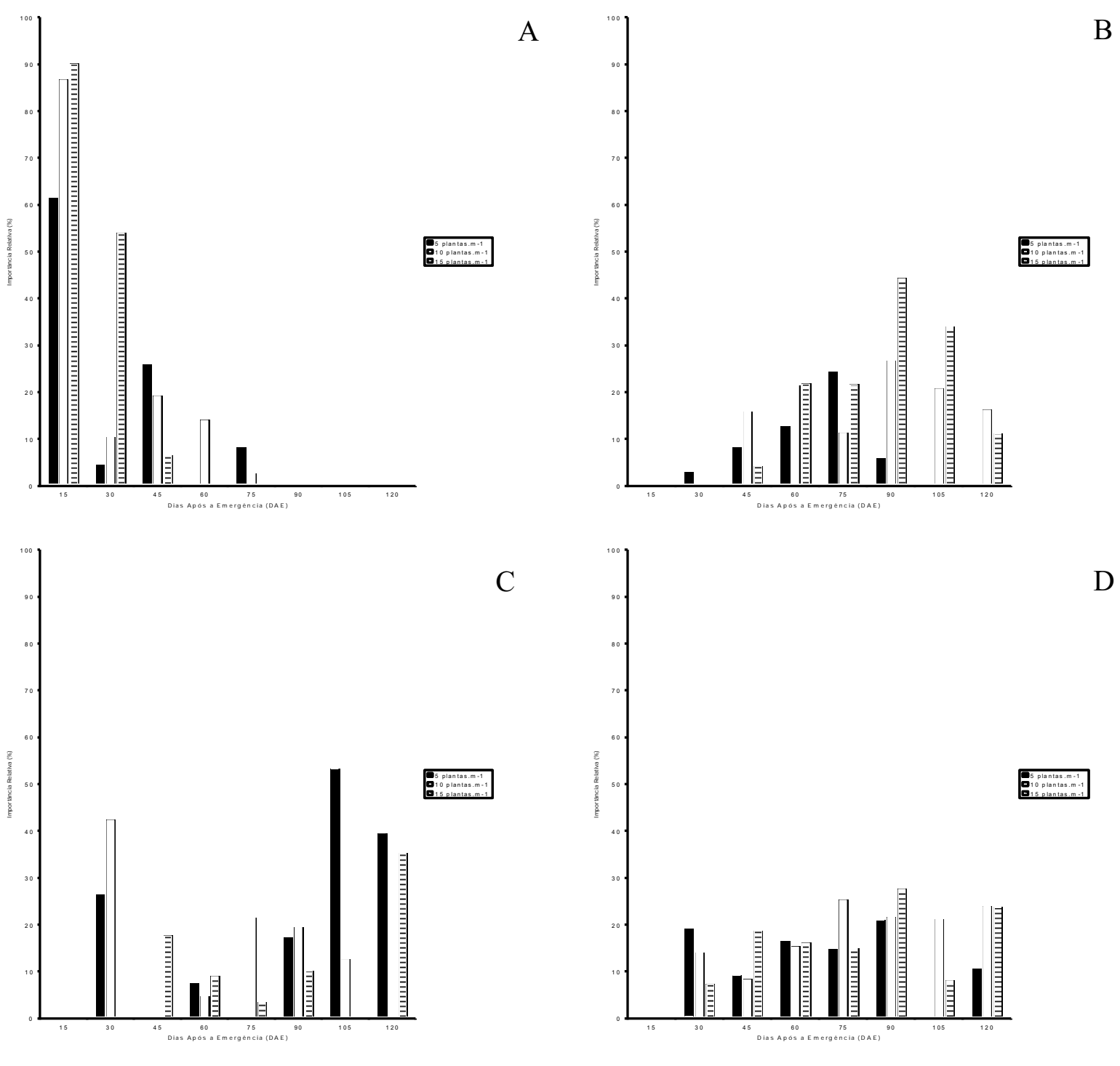

Figura 1A. Importância relativa da tiririca (CYPRO)(A), capim-colchão (DIGSP)(B), capim-colonião (PANMA)(C) e carrapicho-de-carneiro (ACNHI)(D) infestando a cultura do amendoim no espaçamento de 0,60 m entrelinhas e densidade de semeadura de 5, 10 e 15 plantas.m-1. Jaboticabal, SP, 2007/2008. 

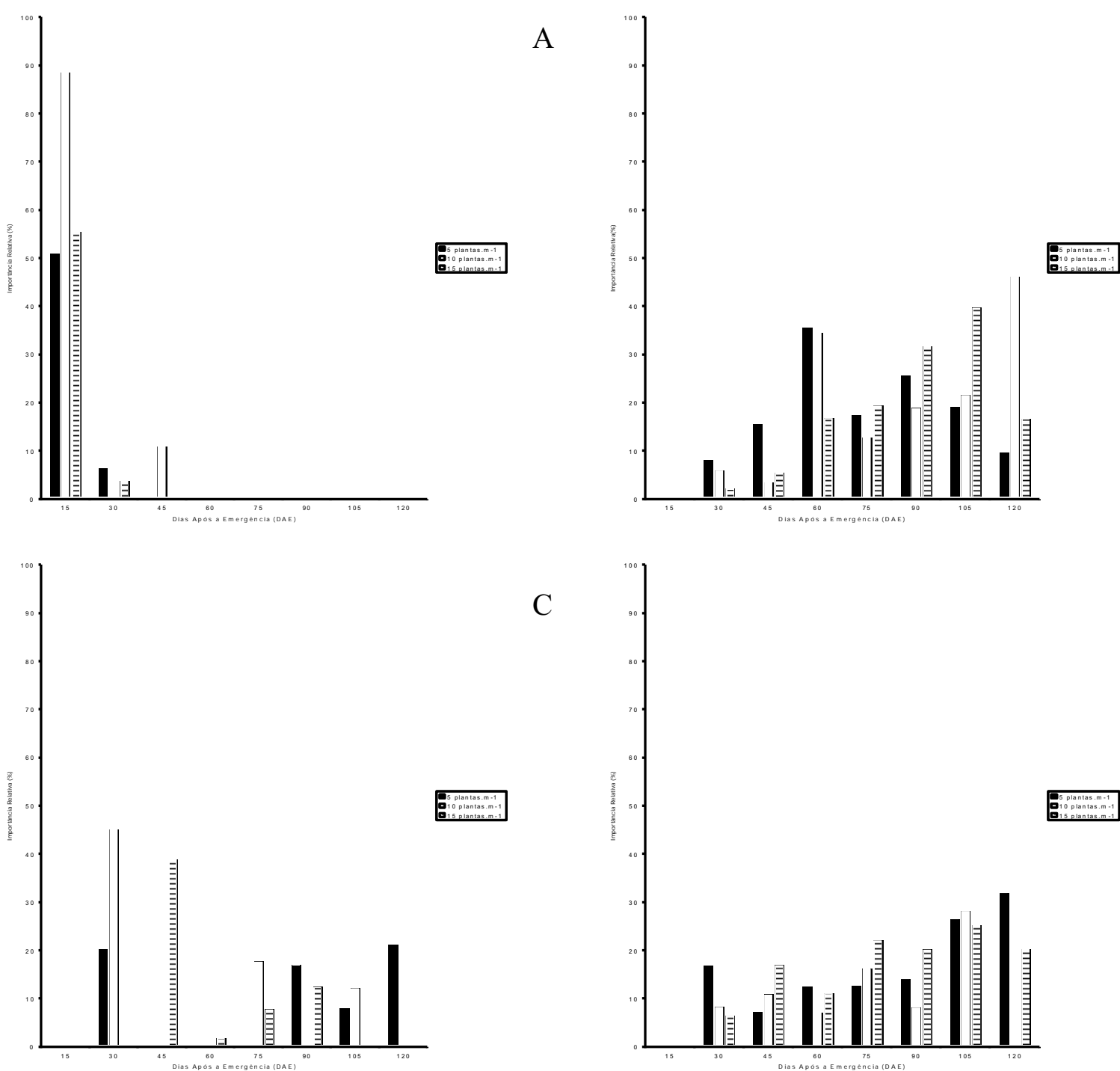

Figura 2A. Importância relativa da tiririca (CYPRO)(A), capim-colchão (DIGSP)(B), capim-colonião (PANMA)(C) e carrapicho-de-carneiro (ACNHI)(D) infestando a cultura do amendoim no espaçamento de 0,90 m entrelinhas e densidade de semeadura de 5, 10 e 15 plantas.m-1. Jaboticabal, SP, 2007/2008. 